WSRC-TR-2005-00543

Revision 0

\title{
IMPACT OF IRRADIATION AND THERMAL AGING ON DWPF SIMULATED SLUDGE PROPERTIES
}

Russell E. Eibling

Michael E. Stone

September 2006

Process Science \& Engineering Section Savannah River National Laboratory Aiken, SC 29808 


\section{DISCLAIMER}

This report was prepared by Washington Savannah River Company (WSRC) for the United States Department of Energy under Contract No. DE-AC09-96SR18500 and is an account of work performed under that contract. Neither the United States Department of Energy, nor WSRC, nor any of their employees makes any warranty, expressed or implied, or assumes any legal liability or responsibility for the accuracy, completeness, or usefulness, of any information, apparatus, or product or process disclosed herein or represents that its use will not infringe privately owned rights. Reference herein to any specific commercial product, process, or service by trademark, name, manufacturer or otherwise does not necessarily constitute or imply endorsement, recommendation, or favoring of same by WSRC or by the United States Government or any agency thereof. The views and opinions of the authors expressed herein do not necessarily state or reflect those of the United States Government or any agency thereof.

\section{Printed in the United States of America}

Prepared For U.S. Department of Energy 
Key Words:

Retention:

\section{IMPACT OF IRRADIATION AND THERMAL AGING ON DWPF SIMULATED SLUDGE PROPERTIES}

Russell E. Eibling

Michael E. Stone

September 2006

Process Science \& Engineering Section Savannah River National Laboratory Aiken, SC 29808

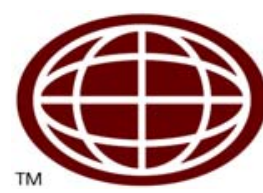




\section{REVIEWS AND APPROVALS}

\section{AUTHOR(S):}

$\overline{\text { R. E. Eibling, Process Science \& Engineering Section }}$ Date

M. E. Stone, Process Science \& Engineering Section Date

\section{TECHNICAL REVIEWERS:}

$\overline{\text { D. C. Koopman, Process Science \& Engineering Section }}$ Date

\section{APPROVERS}

R. E. Edwards, Manager, Process Science \& Engineering Section

Date

C. C. Herman, Manager, Process Engineering Technology

Date

J. E. Occhipinti, Manager, DWPF Process Engineering

Date 


\section{EXECUTIVE SUMMARY}

The research and development programs in support of the Defense Waste Processing Facility (DWPF) and other high-level waste vitrification processes require the use of both nonradioactive waste simulants and actual waste samples. These waste simulants were designed to reproduce the chemical and, if possible, the physical properties of the actual high-level waste. This technical report documents a study on the impact of irradiating a Sludge Batch 3 (SB3) simulant on the physical properties of the sludge, additional tests on producing a SB3 simulant using crossflow filtration and on the impact of aging an SB3 simulant by additional thermal processing.

The SB3 simulants used in this study were based on the simulant composition and recipe developed in FY 2004 and previously documented in WSRC-TR-2004-00578. The physical properties measured were particle size, rheology and crystallinity. The irradiation experiment was performed on an SB3 sludge simulant prepared and characterized in FY2004. The remaining experiments used fresh batches of SB3 simulant prepared in larger batch sizes during this study. These larger batches of simulant did not reproduce the rheological properties that were observed in the SB3 simulant prepared in FY2004 in smaller batches.

The testing performed as part of the effort to enhance the understanding about the production of sludge simulants has demonstrated the complexity of producing a simulant with specific desired physical properties. The following conclusions were made because of these tests:

- The application of a rapid dose of radiation on a sludge simulant did not change the particle size distribution of the simulant.

- The application of a rapid dose of radiation on a sludge simulant did not change the detectable crystalline phases based upon x-ray diffraction.

- Irradiation over a limited time did not modify the rheology of the SB3 sludge simulant.

- SB3 simulant prepared as a part of this study does not match the rheology of SB3 simulant prepared in smaller batches. This suggests that scale-dependent parameters such as shear may be important in determining the product rheology.

- Accelerated aging through thermal treatment increases the sludge crystallinity based upon xray diffraction.

- Particle size does not necessarily relate to the rheological properties of the slurries.

- Accelerated aging reduced the yield stress of the gravity-washed SB3 simulant as a function of both time and temperature. However, the degree of reduction remains small. Extended times (greater than one week) might be necessary to achieve greater reductions.

- Accelerated aging did not reduce and instead appeared to increase the yield stress of the crossflow-washed simulant. This suggests that additional factors such as particle size and particle morphology might be more important than a limited heat treatment.

The results of the current sludge preparation study indicate that there are additional unknown parameters that modify the physical properties of a DWPF sludge simulant. Additional studies are recommended to improve understanding of the important properties (chemical and physical) of DWPF sludges.

- Development of a new simulant should include tests to demonstrate that the simulant is reproducible or that the scale of the simulant preparation affects the simulant properties. 
- Develop an understanding of the specific solids generating steps with respect to parameters such as shear, temperature, and additional species present

- Examine the impact of compositional changes on simulant physical properties.

- Explore the potential for utilizing controlled shear precipitation to produce DWPF precipitated sludge simulants. Methods such as in-line precipitation using in-line mixers or small vessel, continuously stirred reactors could be tested.

- Determine why the application of heat is more effective on some sludge compositions than on other compositions. 


\section{TABLE OF CONTENTS}

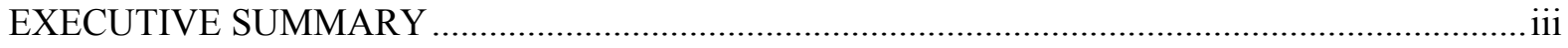

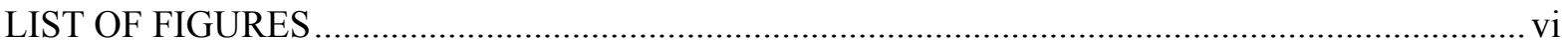

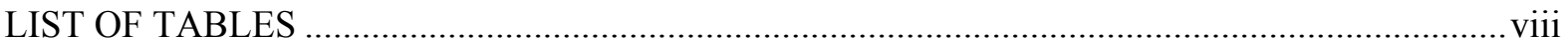

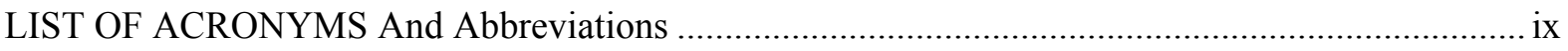

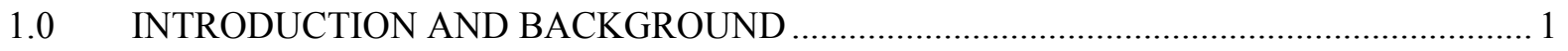

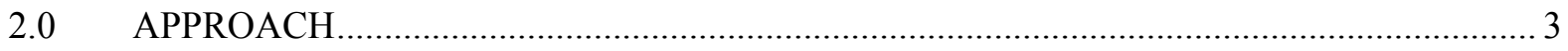

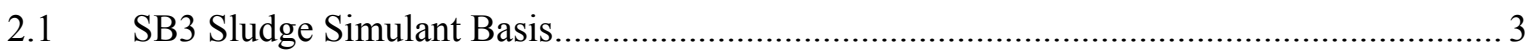

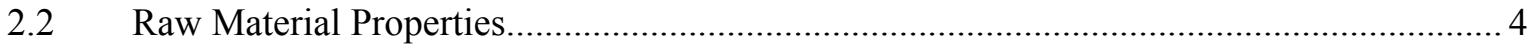

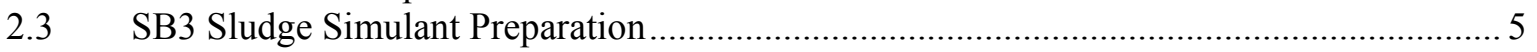

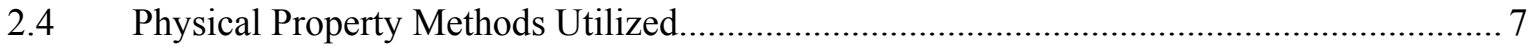

2.4.1 Weight Percent Solids and Density Measurements .................................................... 7

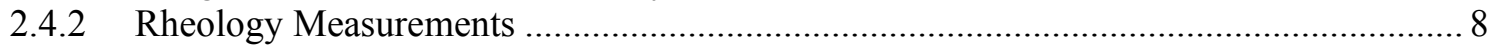

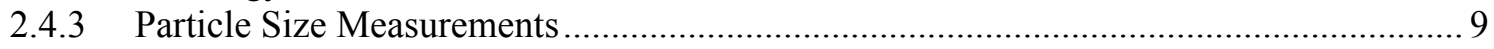

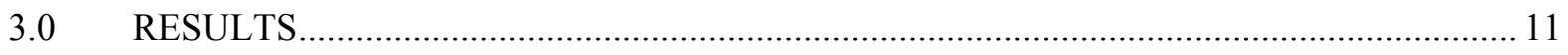

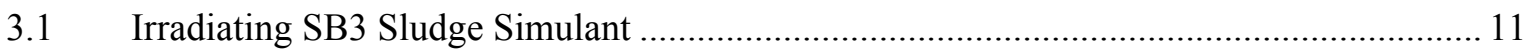

3.2 Gravity-Washed SB3 Sludge Simulant Properties .......................................................... 16

3.3 Thermally Aged, Gravity-Washed SB3 Sludge Simulant.............................................. 21

3.4 Crossflow-Washed SB3 Sludge Simulant Physical Properties .......................................... 31

3.5 Thermally Aged, Crossflow-Washed SB3 Sludge Simulant .............................................. 36

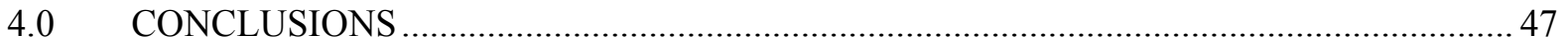

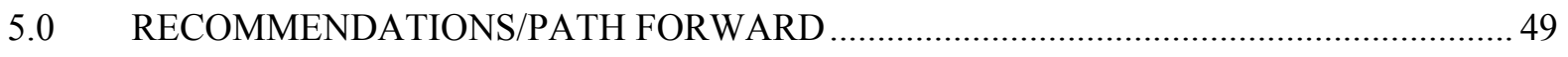

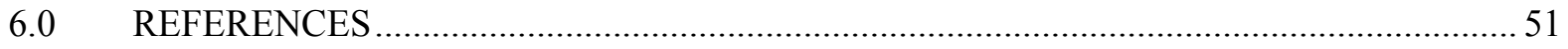

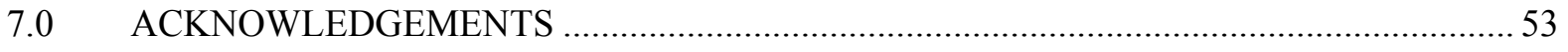

APPENDIX A. Additional Particle Size Distribution Results ........................................................ 55

APPENDIX B. Rheograms for Gravity-Washed and Crossflow-Washed Simulants ........................ 61 


\section{LIST OF FIGURES}

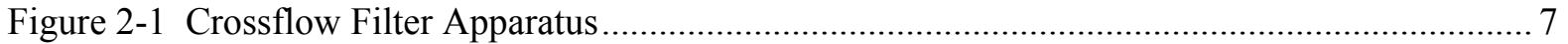

Figure 3-1 Impact of Irradiation on the Particle Size Distribution on a Volume Basis...................... 12

Figure 3-2 Impact of Irradiation on the Number-Based Particle Size Distribution............................ 13

Figure 3-3 Flow Curves of SB3 Sludge Simulant before and after Irradiation ................................. 14

Figure 3-4 X-Ray Diffraction Analysis of the initial Sludge Simulant ............................................ 15

Figure 3-5 X-Ray Diffraction Analysis of the Sludge Simulant after Irradiation ............................. 15

Figure 3-6 Particle Size Results for the 10 Liter Batch of Gravity-Washed SB3 Sludge Simulant .... 17

Figure 3-7 Comparison of Particle Size Distributions (Volume Basis) for Gravity-Washed SB3

Sludge Simulants

Figure 3-8 Comparison of Particle Size Distributions (Number Basis) for Gravity-Washed SB3

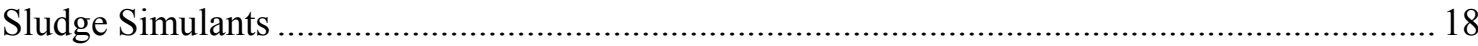

Figure 3-9 Yield Stress as a Function of Insoluble Solids for the Initial Gravity-Washed Sludge

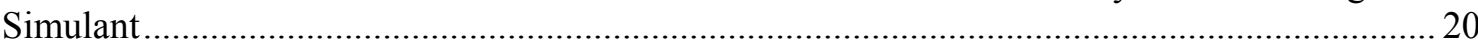

Figure 3-10 Consistency as a Function of Insoluble Solids for the Initial Gravity-Washed Sludge

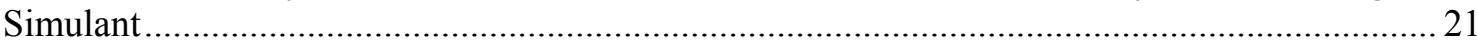

Figure 3-11 X-Ray Diffraction Analysis of the Gravity-Washed SB3 Sludge Simulant .................... 22

Figure 3-12 X-Ray Diffraction Analysis of the Gravity-Washed SB3 Sludge Simulant after

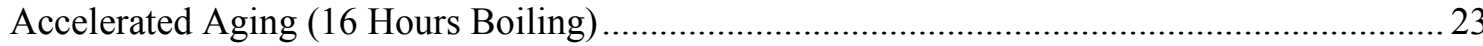

Figure 3-13 Impact of Accelerated Aging at $90{ }^{\circ} \mathrm{C}$ on the Rheology of Gravity-Washed SB3

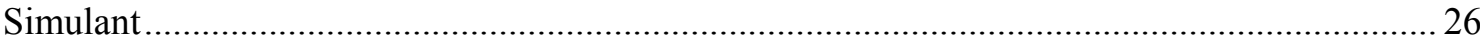

Figure 3-14 Impact of Accelerated Aging by Boiling on the Rheology of Gravity-Washed SB3

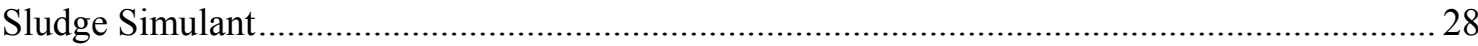

Figure 3-15 Reduction in Yield Stress by Application of Accelerated Aging for Gravity-Washed

SB3 Sludge Simulants .................................................................................................... 28

Figure 3-16 Impact of Accelerated Aging on Gravity-Washed SB3 Sludge Simulant Consistency ... 29

Figure 3-17 Particle Size Distribution (Volume Basis) of the Gravity-Washed SB3 Sludge

Simulant after Accelerated Aging (16 Hours Boiling) ............................................................ 30

Figure 3-18 Particle Size Distribution (Number Basis) of the Gravity-Washed SB3 Sludge

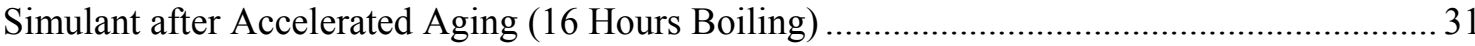

Figure 3-19 Particle Size Distribution Results for Crossflow-Washed SB3 Sludge Simulant............ 32

Figure 3-20 Comparison of Particle Size Distribution (Volume Basis) for Crossflow-Washed and

Gravity-Washed SB3 Sludge Simulants ................................................................................. 33

Figure 3-21 Comparison of Particle Size Distribution (Number Basis) for Crossflow-Washed and

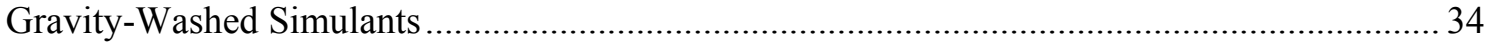

Figure 3-22 Yield Stress Results for the Initial Crossflow-Washed Sludge Simulant ...................... 35

Figure 3-23 Consistency Results for Gravity and Crossflow-Washed SB3 Sludge Simulants ............ 36

Figure 3-24 X-Ray Diffraction Analysis of Crossflow-Washed, SB3 Sludge Simulant..................... 37

Figure 3-25 X-Ray Diffraction Analysis of Crossflow-Washed, SB3 Sludge Simulant after

Accelerated Aging (16 Hours Boiling)....

Figure 3-26 Comparison of Particle Size Distribution (Volume Basis) for Aged Crossflow-

Washed Simulant

Figure 3-27 Comparison of Particle Size Distribution (Numbered Basis) for Aged Crossflow-

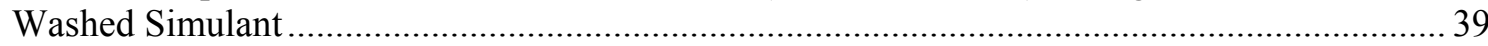

Figure 3-28 Yield Stress of Crossflow-Washed SB3 Simulant after Accelerated Aging at $90{ }^{\circ} \mathrm{C} \ldots . . .42$

Figure 3-29 Consistency of Crossflow-Washed SB3 Simulant after Accelerated Aging at $90{ }^{\circ} \mathrm{C} \ldots . . .42$ 
Figure 3-30 Yield Stress of Crossflow-Washed SB3 Sludge Simulant after Accelerated Aging by

Boiling

Figure 3-31 Consistency of Crossflow-Washed SB3 Sludge Simulant after Accelerated Aging by Boiling

Figure A- 1 Impact of Thermal Aging $\left(90^{\circ} \mathrm{C}\right)$ on Particle Size Distribution Volume Basis on Gravity-Washed SB3 Sludge Simulant........

Figure A- 2 Impact of Thermal Aging $\left(90^{\circ} \mathrm{C}\right)$ on Particle Size Distribution Number Basis on

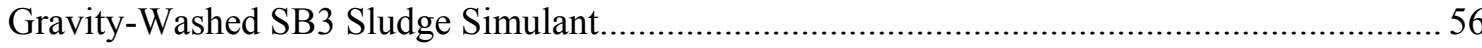

Figure A- 3 Impact of Thermal Aging (Boiling) on Particle Size Distribution Volume Basis for Gravity-Washed SB3 Sludge Simulant.....

Figure A- 4 Impact of Thermal Aging (Boiling) on Particle Size Distribution Number Basis for Gravity-Washed SB3 Sludge Simulant. . .

Figure A- 5 Impact of Thermal Aging $\left(90^{\circ} \mathrm{C}\right)$ on Particle Size Distribution Volume Basis for Crossflow-Washed SB3 Sludge Simulant

Figure A- 6 Impact of Thermal Aging $\left(90^{\circ} \mathrm{C}\right)$ on Particle Size Distribution Number Basis for Crossflow-Washed SB3 Sludge Simulant .58

Figure A- 7 Impact of Thermal Aging (Boiling) on Particle Size Distribution Volume Basis for Crossflow-Washed SB3 Sludge Simulant

Figure A- 8 Impact of Thermal Aging (Boiling) on Particle Size Distribution Number Basis for Crossflow-Washed SB3 Sludge Simulant

Figure B- 1 Rheograms for the Initial Gravity-Washed SB3 Simulant at Varying Concentrations of Insoluble Solids

Figure B- 2 Rheograms for the Gravity-Washed SB3 Simulant After 8 Hours at $90{ }^{\circ} \mathrm{C}$ as a Function of Insoluble Solids.

Figure B- 3 Rheograms for the Gravity-Washed SB3 Simulant After 16 Hours at $90{ }^{\circ} \mathrm{C}$ as a Function of Insoluble Solids....

Figure B- 4 Rheograms for the Gravity-Washed SB3 Simulant After 8 Hours at Boiling as a Function of Insoluble Solids

Figure B- 5 Rheograms for the Gravity-Washed SB3 Simulant After 16 Hours at Boiling as a Function of Insoluble Solids.....

Figure B- 6 Rheograms for the Gravity-Washed SB3 Simulant After 32 Hours at $90{ }^{\circ} \mathrm{C}$ as a Function of Insoluble Solids

Figure B- 7 Rheograms for the Initial Crossflow-Washed SB3 Simulant at Varying Concentrations of Insoluble Solids

Figure B- 8 Rheograms for the Crossflow-Washed SB3 Simulant After 8 Hours at $90{ }^{\circ} \mathrm{C}$ as a Function of Insoluble Solids.

Figure B- 9 Rheograms for the Crossflow-Washed SB3 Simulant After 16 Hours at $90{ }^{\circ} \mathrm{C}$ as a Function of Insoluble Solids.

Figure B- 10 Rheograms for the Crossflow-Washed SB3 Simulant After 8 Hours at Boiling as a Function of Insoluble Solids.....

Figure B- 11 Rheograms for the Crossflow-Washed SB3 Simulant After 16 Hours at Boiling as a Function of Insoluble Solids

Figure B- 12 Rheograms for the Crossflow-Washed SB3 Simulant After 32 Hours at $90^{\circ} \mathrm{C}$ as a Function of Insoluble Solids

Figure B- 13 Rheograms for the Extended-Washed SB3 Simulant After 27 Hours at Boiling as a Function of Insoluble Solids 


\section{LIST OF TABLES}

Table 2-1 Selected Physical Property Results for the Tank 40 Dip Sample ...................................... 3

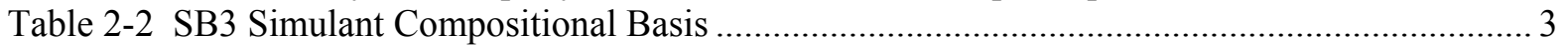

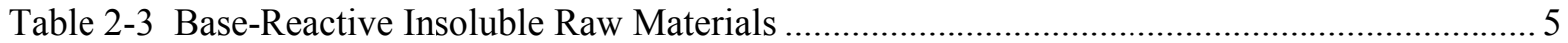

Table 2-4 Particle Size Data Summary for Insoluble Raw Materials................................................. 5

Table 2-5 SB3 Sludge Simulant Preparation Steps …..................................................................... 5

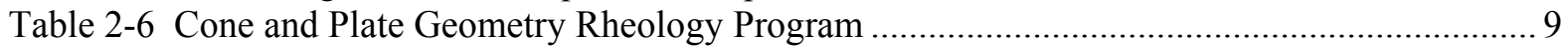

Table 3-1 Physical Properties of the Irradiated Simulant ................................................................... 11

Table 3-2 Particle Size Results for Irradiated Sludge Simulant ....................................................... 12

Table 3-3 Bingham Rheology Model Results for SB3 Sludge Simulant Impacted by Irradiation...... 14

Table 3-4 Gravity-Washed SB3 Sludge Simulant Product ........................................................... 16

Table 3-5 Particle Size Results for Gravity-Washed Sludge Simulant ............................................. 16

Table 3-6 Rheology of Gravity-Washed SB3 Sludge Simulant ....................................................... 19

Table 3-7 Rheology Results for the Gravity-Washed Sludge Simulant after Accelerated Aging

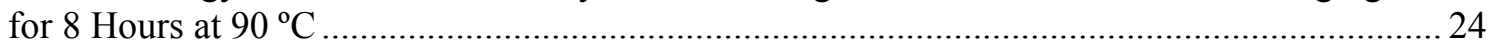

Table 3-8 Rheology Results for the Gravity-Washed Sludge Simulant after Accelerated Aging

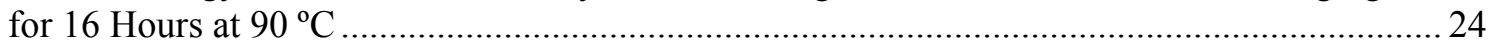

Table 3-9 Rheology Results for the Gravity-Washed Sludge Simulant after Accelerated Aging

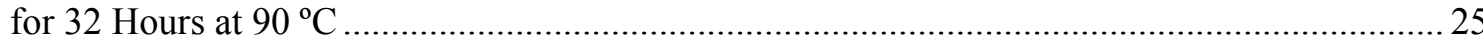

Table 3-10 Rheology Results for the Gravity-Washed Sludge Simulant after Accelerated Aging

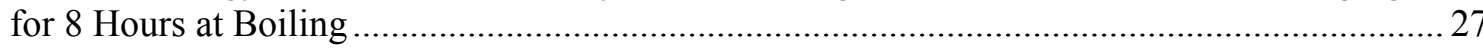

Table 3-11 Rheology Results for the Gravity-Washed Sludge Simulant after Accelerated Aging

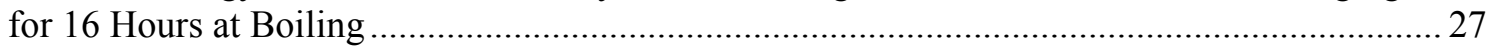

Table 3-12 Particle Size Results for Sludge Simulants after Accelerated Aging at $90{ }^{\circ} \mathrm{C}$................ 29

Table 3-13 Particle Size Results for Sludge Simulants after Accelerated Aging at Boiling ............... 30

Table 3-14 Crossflow-Washed SB3 Sludge Simulant Product ........................................................ 32

Table 3-15 Particle Size Results for Crossflow-Washed SB3 Sludge Simulant ............................... 33

Table 3-16 Rheology Results for the Crossflow- Washed Sludge Simulant ...................................... 34

Table 3-17 Particle Size Results for Crossflow-Washed Sludge Simulants Aged at $90{ }^{\circ} \mathrm{C}$................ 38

Table 3-18 Particle Size Results for Crossflow-Washed Sludge Simulants Aged at Boiling ............. 38

Table 3-19 Rheology of Crossflow-Washed Sludge Simulant after 8 Hours of Accelerated Aging at $90^{\circ} \mathrm{C}$

Table 3-20 Rheology of Crossflow-Washed Sludge Simulant after 16 Hours of Accelerated Aging at $90^{\circ} \mathrm{C}$.

Table 3-21 Rheology of Crossflow-Washed Sludge Simulant after 32 Hours of Accelerated Aging at $90^{\circ} \mathrm{C}$.

Table 3-22 Rheology of Crossflow-Washed Sludge Simulant after 8 Hours of Accelerated Aging at Boiling .....

Table 3-23 Rheology of Crossflow-Washed Sludge Simulant after 16 Hours of Accelerated Aging at Boiling

Table 3-24 Rheology of Extended-Wash Sludge Simulant after 27 Hours of Accelerated Aging at Boiling 


\section{LIST OF ACRONYMS AND ABBREVIATIONS}

ACTL

$\mathrm{AD}$

cP

CPC

CSSA

DWPF

IC

ICPES

$\mathrm{mL}$

$\mathrm{Pa}$

Psi

RPP

SB3

SRAT

SRNL

XRD

\author{
Aiken County Technology Laboratory \\ Analytical Development \\ Centipoise \\ Chemical Process Cell \\ Calculated Specific Surface Area \\ Defense Waste Processing Facility \\ Ion Chromatography \\ Inductively Coupled Plasma Emission Spectrophotometer \\ milliliter \\ Pascals \\ pounds per square inch \\ River Protection Project \\ Sludge Batch 3 \\ Slurry Receipt Adjustment Tank \\ Savannah River National Laboratory \\ $\mathrm{X}$-ray Diffraction
}




\subsection{INTRODUCTION AND BACKGROUND}

The research and development programs in support of the Defense Waste Processing Facility (DWPF) and other high-level waste vitrification processes require the use of both nonradioactive waste simulants and actual waste samples. While actual waste samples are the ideal materials to study, acquiring large quantities of actual waste is difficult and expensive. Tests utilizing actual high-level waste require the use of expensive shielded cells facilities to provide sufficient shielding for the researchers. Nonradioactive waste simulants have been used for laboratory testing, pilot-scale testing and full-scale integrated facility testing. These waste simulants were designed to reproduce the chemical and, if possible, the physical properties of the actual high-level waste. This technical report documents a study on the impact of irradiating a Sludge Batch 3 (SB3) simulant and of additional tests on aging a SB3 simulant by additional thermal processing.

Prior simulant development studies examined methods of producing sludge and supernate simulants and processes that could be used to alter the physical properties of the simulant to more accurately mimic the properties of actual waste. Development of a precipitated sludge simulant for the River Protection Project (RPP) demonstrated that the application of heat for a period of time could significantly alter the rheology of the sludge simulant. ${ }^{1}$ The RPP precipitated simulant used distillation to concentrate the sludge solids and produced a reduction in sludge yield stress of up to $80 \%$ compared to the initial sludge properties. Observations at that time suggested that a substantial fraction of the iron hydroxide had converted to the oxide during the distillation. DWPF sludge simulant studies showed a much smaller reduction in yield stress $(\sim 10 \%)$, demonstrated the impact of shear on particle size, and showed that smaller particle sizes yielded higher yield stress products. ${ }^{2}$

The current study documented in this report focuses on the SB3 sludge composition and recipe developed during the previous year as part of the simulant development program. The study examines the impact of a rapid dose of radiation on the physical properties of the SB3 simulant, the effect of temperature and time on the application of heat as a simulant aging mechanism, and the application of crossflow filtration to the production of an all-metals-precipitated SB3 sludge simulant. 
WSRC-TR-2005-00543

Revision 0

This page intentionally left blank. 


\subsection{APPROACH}

\subsection{SB3 Sludge Simulant Basis}

The compositional basis for the Sludge Batch 3 simulant used in this study is derived from the composition of two dip samples collected from Tank 40H in March 2004. ${ }^{3}$ The physical properties of the Tank 40H sample are shown in Table 2-1 and the planned elemental and anion composition of the SB3 simulant are shown in Table 2-2.

Table 2-1 Selected Physical Property Results for the Tank 40 Dip Sample

\begin{tabular}{|c|c|c|}
\hline Physical Property & Value & Units \\
\hline Density & 1.19 & $\mathrm{~g} / \mathrm{mL}$ \\
\hline Weight \% Total Solids & 20.0 & $\%$ \\
\hline Weight \% Insoluble Solids & 14.8 & $\%$ \\
\hline Weight \% Soluble Solids & 5.2 & $\%$ \\
\hline Bingham Yield Stress & 3.3 & $\mathrm{~Pa}$ \\
\hline Bingham Consistency & 5.6 & $\mathrm{cP}$ \\
\hline
\end{tabular}

Table 2-2 SB3 Simulant Compositional Basis

\begin{tabular}{|c|c|c|c|c|}
\hline Basis & Solids & Slurry & Slurry & Concentration \\
\hline Analyte & microgram/gram & microgram/gram & g/L slurry & moles/Liter \\
\hline $\mathrm{Ag}$ & 300 & & 0.0714 & $6.62 \mathrm{E}-04$ \\
\hline $\mathrm{Al}$ & 60400 & & 14.3752 & $5.33 \mathrm{E}-01$ \\
\hline $\mathrm{B}$ & 100 & & 0.0238 & $2.20 \mathrm{E}-03$ \\
\hline $\mathrm{Ba}$ & 500 & & 0.1190 & $8.67 \mathrm{E}-04$ \\
\hline $\mathrm{C}_{2} \mathrm{O}_{4}^{-2}$ & & 1033 & 1.2293 & $1.40 \mathrm{E}-02$ \\
\hline $\mathrm{Ca}$ & 16600 & & 3.9508 & $9.86 \mathrm{E}-02$ \\
\hline $\mathrm{Cd}$ & 1900 & & 0.4522 & $4.02 \mathrm{E}-03$ \\
\hline $\mathrm{Ce}$ & 1100 & & 0.2618 & $1.87 \mathrm{E}-03$ \\
\hline $\mathrm{Cl}$ & & 200 & 0.2380 & $6.71 \mathrm{E}-03$ \\
\hline $\mathrm{CO}_{3}^{-2}$ & & & 7.321 & $1.22 \mathrm{E}-01$ \\
\hline Cr(TOTAL) & 2500 & & 0.5950 & $1.14 \mathrm{E}-02$ \\
\hline $\mathrm{Cu}$ & 300 & & 0.0714 & $1.12 \mathrm{E}-03$ \\
\hline $\mathrm{F}$ & 235 & 235 & 0.2797 & $1.47 \mathrm{E}-02$ \\
\hline $\mathrm{Fe}$ & 194400 & & 46.2672 & $8.28 \mathrm{E}-01$ \\
\hline $\mathrm{Gd}$ & 500 & & 0.1190 & $7.57 \mathrm{E}-04$ \\
\hline $\mathrm{K}$ & 3300 & & 0.7854 & $2.01 \mathrm{E}-02$ \\
\hline $\mathrm{La}$ & 400 & & 0.0952 & $6.85 \mathrm{E}-04$ \\
\hline $\mathrm{Li}$ & 400 & & 0.0952 & $1.37 \mathrm{E}-02$ \\
\hline $\mathrm{Mg}$ & 16700 & & 3.9746 & $1.64 \mathrm{E}-01$ \\
\hline $\mathrm{Mn}$ & 39500 & & 9.4010 & $1.71 \mathrm{E}-01$ \\
\hline Mo & 500 & & 0.1190 & $1.24 \mathrm{E}-03$ \\
\hline $\mathrm{Na}$ & 138470 & & 32.9559 & $1.43 \mathrm{E}+00$ \\
\hline
\end{tabular}


Table 2-2 SB3 Simulant Compositional Basis Continued

\begin{tabular}{|c|c|c|c|c|}
\hline Basis & Solids & Slurry & Slurry & Concentration \\
\hline Analyte & microgram/gram & microgram/gram & g/L slurry & moles/Liter \\
\hline $\mathrm{Ni}$ & 10900 & & 2.5942 & $4.42 \mathrm{E}-02$ \\
\hline $\mathrm{NO}_{2}^{-}$ & & 15462 & 18.3998 & $4.00 \mathrm{E}-01$ \\
\hline $\mathrm{NO}_{3}^{-}$ & & 10536 & 12.5378 & $2.02 \mathrm{E}-01$ \\
\hline $\mathrm{OH}^{-}$ & & & 7.3132 & $4.30 \mathrm{E}-01$ \\
\hline P (by ICP-ES) & 4300 & & 1.0234 & $3.30 \mathrm{E}-02$ \\
\hline $\mathrm{Pb}$ & 600 & & 0.1428 & $6.89 \mathrm{E}-04$ \\
\hline $\mathrm{PO}_{4}^{-3}$ (by IC) & & 940 & 1.1186 & $1.18 \mathrm{E}-02$ \\
\hline $\mathrm{S}$ & 2900 & & 0.6902 & $2.15 \mathrm{E}-02$ \\
\hline $\mathrm{Sb}$ & 600 & & 0.1428 & $1.17 \mathrm{E}-03$ \\
\hline $\mathrm{Si}$ & 4000 & & 0.9520 & $3.39 \mathrm{E}-02$ \\
\hline $\mathrm{Sn}$ & 500 & & 0.1190 & $1.00 \mathrm{E}-03$ \\
\hline $\mathrm{SO}_{4}^{-2}$ & & 1689 & 2.0099 & $2.09 \mathrm{E}-02$ \\
\hline $\mathrm{Sr}$ & 4200 & & 0.9996 & $1.14 \mathrm{E}-02$ \\
\hline Ti & 200 & & 0.0476 & $9.94 \mathrm{E}-04$ \\
\hline $\mathrm{U}$ & 69900 & & 16.6362 & $6.99 \mathrm{E}-02$ \\
\hline $\mathrm{V}$ & 100 & & 0.0238 & $4.67 \mathrm{E}-04$ \\
\hline $\mathrm{Zn}$ & 300 & & 0.0714 & $1.09 \mathrm{E}-03$ \\
\hline $\mathrm{Zr}$ & 100 & & 0.0238 & $2.61 \mathrm{E}-04$ \\
\hline
\end{tabular}

The elemental composition was based upon inductively coupled plasma emission spectrophotometry (ICP-ES) and the anions were based upon ion chromatography (IC). The hydroxide value was based upon an acid-base titration. The following species were assumed to be present as soluble components only for the purposes of calculating a supernate composition: $\mathrm{Na}, \mathrm{Li}, \mathrm{K}, \mathrm{B}$ (as borate, $\mathrm{BO}_{3}{ }^{-3}$ ), oxalate, chloride, fluoride, hydroxide, nitrite, nitrate, phosphate, and sulfate. Carbonate was expected to be present but not analyzed on the Tank 40 dip samples. Therefore, the concentration of carbonate in the supernate (0.122 moles/liter) was based on DWPF batch 275 Sludge Receipt and Adjustment Tank (SRAT) receipt value of $870 \mathrm{mg} / \mathrm{kg}$ total inorganic carbon (TIC). This value was corrected for assumed SRAT heel volume of 1500 gallons, transfer line flush water volume of 1000 gallons and sludge batch volume of 6000 gallons and then converted from a carbon basis to a carbonate basis (60/12). Calculating a charge balance between the anions and cations shows an imbalance of 0.185 moles of excess negative charge. To correct this imbalance, an additional 0.185 moles of sodium ion was added to the simulant composition.

Since this program was based on examining the physical properties of the sludge simulants and all of the simulants were prepared based on the same compositional recipe, the composition of each test batch was not chemically determined as part of the tests.

\subsection{Raw Material Properties}

The raw materials used for the production of the waste sludge were obtained as reagent grade chemicals. The base-reactive insoluble solids other than aluminum were added near the end of sludge preparation to minimize reaction with the final hydroxide concentration. These base-reactive compounds were added after caustic precipitation was complete and removal of the excess nitrate anions by sludge washing was also complete. Table 2-3 lists the raw materials used in preparing the sludge simulants. Since these solids were assumed to remain insoluble (though some dissolution is possible), the initial particle size data for the base-reactive additives is summarized in Table 2-4. 
Table 2-3 Base-Reactive Insoluble Raw Materials

\begin{tabular}{|c|c|c|}
\hline Material & Product Name & Material Supplier \\
\hline Silica, $\mathrm{SiO}_{2}$ & $\begin{array}{c}\text { Silicon(IV) Oxide, 99.5\% } \\
-400 \text { mesh, Cat \#13024 }\end{array}$ & Alfa Aesar \\
\hline Tin (IV) Oxide, $\mathrm{SnO}_{2}$ & $\begin{array}{c}\text { Tin (IV) Oxide,-325 Mesh, } \\
99.9 \%, \mathrm{Cat} \# 24465-1\end{array}$ & Sigma-Aldrich \\
\hline Titanium Dioxide, $\mathrm{TiO}_{2}$ & $\begin{array}{c}\text { Titanium(IV) Oxide, } \\
\text { powder, }<5 \text { micron, 99.9+\%, } \\
\text { Cat \#22422-7 }\end{array}$ & Sigma-Aldrich \\
\hline \multicolumn{2}{|c}{} \\
\hline
\end{tabular}

Table 2-4 Particle Size Data Summary for Insoluble Raw Materials

\begin{tabular}{|c|c|c|c|c|}
\hline $\begin{array}{c}\mathrm{Raw} \\
\text { Material }\end{array}$ & $\begin{array}{c}\text { Mean - } \\
\text { Volume, } \\
\text { microns }\end{array}$ & $\begin{array}{c}\text { Mean - } \\
\text { Number, } \\
\text { microns }\end{array}$ & $\begin{array}{c}\text { Mean - } \\
\text { Area, } \\
\text { microns }\end{array}$ & $\begin{array}{c}\text { Calculated } \\
\text { Specific } \\
\text { Surface } \\
\text { Area, } \mathrm{m}^{2} / \mathrm{cm}^{3}\end{array}$ \\
\hline $\mathrm{SiO}_{2}$ & 3.45 & 0.78 & 1.8 & 3.33 \\
\hline $\mathrm{SnO}_{2}$ & 1.31 & 0.45 & 0.84 & 7.12 \\
\hline $\mathrm{TiO}_{2}$ & 3.95 & 0.16 & 0.68 & 8.85 \\
\hline
\end{tabular}

\subsection{SB3 Sludge Simulant Preparation}

The SB3 sludge simulant prepared during this project was based upon the preparation methods which best matched the physical properties of the actual waste as reported in the report on the earlier research. ${ }^{2}$ In prior work, coprecipitation of aluminum with iron and the other metal nitrates gave a simulant whose rheology approached that of the actual waste. The steps involved in preparing the SB3 simulant are listed in Table 2-5.

Table 2-5 SB3 Sludge Simulant Preparation Steps

\begin{tabular}{|c|l|}
\hline Step \# & \multicolumn{1}{c|}{ Process } \\
\hline $\mathbf{1}$ & $\begin{array}{l}\text { Combine the following metal nitrates and dissolve: } \mathrm{Fe}, \mathrm{Al}, \\
\mathrm{Ni}, \mathrm{Zr}, \mathrm{Ce}, \mathrm{Gd}, \mathrm{La}, \mathrm{Ba}, \mathrm{Ca}, \mathrm{Cd}, \mathrm{Cr}, \mathrm{Cu}, \mathrm{Mg}, \mathrm{Pb}, \mathrm{Sr}, \mathrm{Zn}, \\
\text { and } \mathrm{Ag} .\end{array}$ \\
\hline $\mathbf{2}$ & $\begin{array}{l}\text { Add potassium permanganate to the metal nitrate solution } \\
\text { and mix to dissolve. While maintaining good mixing, add } \\
\text { manganous nitrate solution to precipitate } \mathrm{MnO}_{2} .\end{array}$ \\
\hline $\mathbf{3}$ & $\begin{array}{l}\text { Precipitate the metals by addition of an } 8 \text { molar or greater } \\
\text { NaOH solution while monitoring the slurry pH and } \\
\text { maintaining good mixing. The pH target for completion of } \\
\text { the precipitation is between pH } 10 \text { and pH } 11 \text { using caustic } \\
\text { addition. }\end{array}$ \\
\hline
\end{tabular}


Table 2-5 SB3 Sludge Simulant Preparation Steps Continued

\begin{tabular}{|c|c|}
\hline Step \# & Process \\
\hline 4 & $\begin{array}{l}\text { Add } 0.4 \text { liters of a } 0.6 \text { molar sodium carbonate solution per } \\
\text { liter of precipitated sludge to convert moderately soluble } \\
\text { hydroxides into less soluble carbonates. }\end{array}$ \\
\hline 5 & $\begin{array}{l}\text { Stop mixing and allow the sludge to settle for } 24-48 \text { hours } \\
\text { before decanting and disposing of the clear supernate (high } \\
\text { in sodium nitrate solution) }\end{array}$ \\
\hline 6 & $\begin{array}{l}\text { Wash the settled sludge using } \mathrm{pH} 11 \text { inhibited water }(0.001 \\
\left.\text { molar } \mathrm{NaNO}_{2} \text { and } 0.001 \text { molar } \mathrm{NaOH}\right) \text { per volume of } \\
\text { settled sludge until the nitrate anion concentration in the } \\
\text { supernate is less than the target sludge supernate } \\
\text { composition. }\end{array}$ \\
\hline 7 & $\begin{array}{l}\text { After confirming that the residual soluble nitrate } \\
\text { concentration in the supernate is less than the target sludge } \\
\text { supernate composition }(<5000 \mathrm{mg} / \mathrm{Liter}) \text {, add the } \\
\text { following base-reactive insoluble solids while maintaining } \\
\text { good mixing: } \mathrm{SiO}_{2}, \mathrm{SnO}_{2} \text {, and } \mathrm{TiO}_{2} \text {. }\end{array}$ \\
\hline 8 & $\begin{array}{l}\text { Determine the volume of sludge produced. This can be } \\
\text { done by measuring the sludge mass and the density of the } \\
\text { sludge and calculating the volume or by directly measuring } \\
\text { the volume. }\end{array}$ \\
\hline 9 & $\begin{array}{l}\text { Add the salts necessary to match the supernate } \\
\text { concentrations for the soluble species. }\end{array}$ \\
\hline
\end{tabular}

The sludge was precipitated in a polypropylene vessel, 14 3/8 inches wide by $18 \frac{1}{2}$ inches deep, produced by removing the top portion of a 50 Liter polypropylene carboy. Agitation was provided by a high shear, Rushton radial flow impeller (3.5 inch diameter) operating at a minimum rotational speed of $300 \mathrm{rpm}$. The temperature and $\mathrm{pH}$ was monitored during the precipitation process. The subsurface addition of sodium hydroxide was made at a rate of 5 to $10 \mathrm{~mL} /$ minute. The precipitated sludge requires washing in Step 6 (above) to remove the excess nitrate anion to a low enough concentration to allow adjustment to the final target nitrate concentration.

Sludge washing can be completed by using either a sequential batch process or a continuous process. In this report, the term "Gravity-Washed" refers to a sludge washing procedure, which is based upon a series of sequential dilution steps with gravity-induced settling followed by supernate decanting between each of the steps. The continuous washing method utilized for this report was based on crossflow filtration. The crossflow filter system consisted of two parallel two feet long, 0.5 inch ID Mott sintered metal tubes rated at 0.1 micron pore size. The crossflow filtration system used in this study is shown in Figure 2-1. The sludge was pumped through the sintered metal tube bundle at 4.5 gallons/minute at 7-10 psi using a Moyno Model 33304 progressive cavity pump. Washing was accomplished by adding wash water $(0.001$ molar $\mathrm{NaOH}$ and 0.001 molar $\left.\mathrm{NaNO}_{2}\right)$ at the same rate that permeate was removed $(\sim 25 \mathrm{~mL} / \mathrm{minute})$. 


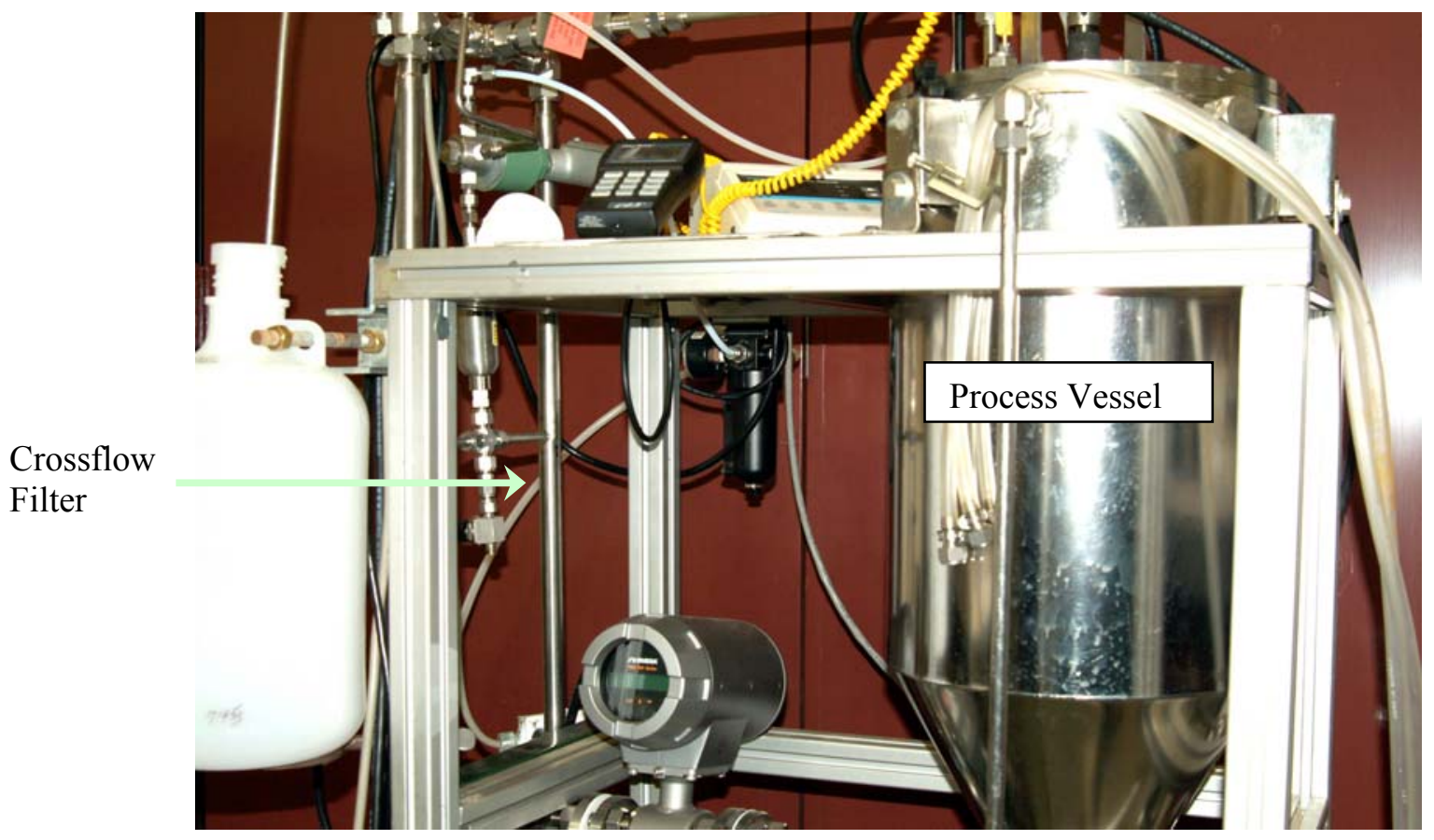

Figure 2-1 Crossflow Filter Apparatus

Three batches of SB3 sludge simulant were studied during this project. The first batch of sludge was produced during the FY2004 simulant preparation studies and is labeled as the "Test 5 Heat Treatment after Washing Method" sludge in the FY2004 report. ${ }^{2}$ The "Test 5" Sludge was used in testing the impact of irradiation on the physical properties of the sludge simulant. The other two batches of SB3 simulant were prepared during this project. Approximately twenty-four liters of the "Gravity-Washed" SB3 sludge simulant was prepared as the first batch of simulant based on the steps listed in Table 2-5. The second batch of SB3 simulant, approximately 35 liters, was prepared using the continuous washing by crossflow filtration process. A portion of the "Crossflow Filtered" simulant was transferred to David Koopman for use in the CPC studies on Hydrogen evolution in the SRAT. ${ }^{4}$ These two large batches of SB3 simulant were used to study the impact of accelerated aging by thermally treating the sludge simulant.

\subsection{Physical Property Methods Utilized}

The physical properties measured during this project include weight percent solids (total solids and total dissolved solids in the supernate), sludge density, sludge rheology and particle size distribution. The methods used to measure each of these properties are described below.

\subsubsection{Weight Percent Solids and Density Measurements}

The weight percent solids were determined using a Mettler Toledo HR73P Halogen Moisture Analyzer. The HR73P is programmed to heat the sample to $105^{\circ} \mathrm{C}$ and monitor the mass of the sample until the change in mass is less than or equal to $1 \mathrm{mg}$ over a period of 130 seconds. The advantage of this method is that a weight percent solids analysis can be performed in less than 20 minutes while a complete analysis of total solids in the sludge and dissolved solids in the supernate can take less than an hour. The homogenous sample (slurry or liquid) is placed on a glass fiber pad and the pad placed in the HR73P. The HR73P weighs the sample. The initial mass of the sample is the total mass $\left(\mathrm{m}_{\mathrm{tt}}\right)$. The sample is then heated by the infrared radiation from a Halogen lamp to $105^{\circ} \mathrm{C}$ (controlled by a thermocouple) to drive off all the water (assuming mass loss is only from water) and the resulting remaining mass is the total 
solids $\left(\mathrm{m}_{\mathrm{ts}}\right)$ in the sample. The weight percent ( $\mathrm{wt} \%$ ) total solids (TS) of the sludge was determined using equation [1].

$$
w t \%_{t s}=\frac{m_{t s}}{m_{t t}} \times 100 \%
$$

A sample of the slurry is centrifuged (at 4332 gravities) to obtain the supernate. The resulting supernate is then processed through a $0.45 \mu \mathrm{m}$ filter. A sample of the filtered supernate is then placed on a glass fiber pad, placed in the HR73P, and weighed. The mass of sample used is the total mass of the supernate $\left(\mathrm{m}_{\mathrm{st}}\right)$. The sample is then heated by the Halogen lamp to $105^{\circ} \mathrm{C}$ to drive off all the water and the resulting remaining mass is the total dissolved solids $\left(\mathrm{m}_{\mathrm{ds}}\right)$ in the supernate. The weight percent of total dissolved solids (DS) in the supernate is determined using equation [2]. This analysis assumes that all the solids in the resulting supernate are dissolved.

$$
w t \%_{d s}=\frac{m_{d s}}{m_{s t}} \times 100 \%
$$

The weight percent of insoluble solids (IS) and soluble solids (SS) of the slurry are then calculated by the following conservation of mass relationships, equations [3] and [4] respectively.

$$
\begin{gathered}
w t \%_{i s}=\frac{w t \%_{t s}-w t \%_{d s}}{100 \%-w t \%_{d s}} \times 100 \% \\
w t \%_{s s}=w t \%_{t s}-w t \%_{i s}
\end{gathered}
$$

Density was determined using an Anton Paar DMA 4500 density meter. The density meter determines the density of a sample by measuring the resonant frequency of a sample-filled $U$ tube at a specified temperature.

\subsubsection{Rheology Measurements}

Slurry rheology measurements were performed using a Haake RS600 rheometer at $25{ }^{\circ} \mathrm{C}$. The rheometer uses a Searle type measuring system, where both speed and torque are measured at the rotating shaft. The rheometer was operated in the controlled rate mode for all of the data reported in this report. A few measurements were also made in the controlled stress mode when additional clarification of a rheology result was needed. The measuring geometry used was the cone and plate (60 $\mathrm{mm} \mathrm{Ti} / 2$ degree) geometry.

Flow curves were obtained by linearly varying the shear rate from 0 to 600 seconds $^{-1}$ over a given time period. The program details for the flow curves are listed in Table 2-6. The measured shear stresses for the up and down flow curves were fitted to the Bingham Plastic rheology model (equation 5) over the shear rate range of 50 to 500 seconds $^{-1}$.

$$
\tau=\tau_{0}+\eta_{0} \dot{\gamma}
$$




$$
\begin{aligned}
& \tau=\text { shear stress, } \mathrm{Pa} \\
& \tau_{0}=\text { Bingham Yield Stress, } \mathrm{Pa} \\
& \dot{\gamma}=\text { Shear rate, } 1 / \text { seconds } \\
& \eta_{0}=\text { Bingham consistency, } \mathrm{mPa} . \sec \text { (or cP) }
\end{aligned}
$$

The upper limit for the fitted shear rate region was adjusted to a lower value of shear rate when necessary to avoid nonlaminar flow conditions.

\section{Table 2-6 Cone and Plate Geometry Rheology Program}

\begin{tabular}{|c|c|c|}
\hline $\begin{array}{c}\text { Program } \\
\text { Section }\end{array}$ & $\begin{array}{c}\text { Shear rate, } \\
\text { seconds }^{-1}\end{array}$ & $\begin{array}{c}\text { Time, } \\
\text { minutes }\end{array}$ \\
\hline Up Curve & 0 to 600 & 5 \\
\hline Hold Period & 600 & 1 \\
\hline Down Curve & 600 to 0 & 5 \\
\hline
\end{tabular}

\subsubsection{Particle Size Measurements}

Particle size analysis was obtained by submitting samples to Analytical Development for analysis. Samples were analyzed with a Microtrac S3000 Tri-laser Particle Size Analyzer. This instrument uses angular light scattering techniques to measure the particle size distribution. Preparation of the samples for analysis by the Microtrac consists of dilution of the slurry with water. The particle size distribution can be expressed in terms of a volume distribution, number distribution or area distribution. In this report, the graphical display of particle size data will use the volume and number distributions. The calculated mean of the volume, number and area distributions will also be reported. It should be noted that the mean for a volume distribution is weighted toward the larger particles while the mean for the number distribution is weighted toward the smallest particles. The calculated specific surface area in meters ${ }^{2} / \mathrm{cm}^{3}$ is based on an assumption of smooth, solid spherical particles and does not reflect porosity or topology of the particles. 
WSRC-TR-2005-00543

Revision 0

This page intentionally left blank. 


\subsection{RESULTS}

\subsection{Irradiating SB3 Sludge Simulant}

The long-term storage of high-level waste subjects the waste to several conditions that can modify the waste and thereby change the physical properties of the waste. These conditions include the chemical environment, the radiation exposure, elevated temperatures and, of course, the duration of storage. Prior sludge development focused on producing a simulant that replicated the properties of a specific sludge from the appropriate chemical environment. Only limited testing on the impact of higher temperatures on simulated sludge properties have been performed. No tests on the impact of radiation on the properties of a simulated sludge have been conducted in earlier simulant development studies.

Radiation affects solids by producing defects in the solid matrix. These defects consist of atom displacements and changes in electronic configurations. These changes can alter the surfaces of the solids (changing rheology and particle size distributions), produce chemical reactions or introduce structural changes. This portion of the study tests the impact of irradiation on the physical properties of simulated sludge by examining the particle size distribution, the rheology and the crystalline phases as detected by $\mathrm{x}$-ray diffraction $(\mathrm{XRD})$ before and after irradiation.

SB3 simulated sludge produced during the FY2004 simulant study (Test 5 simulant) was chosen for testing the effect of radiation on the simulant. Approximately $500 \mathrm{~mL}$ of the SB3 simulated sludge was placed in a one liter, 316L stainless steel bottle. The bottle was weighed and placed in a gamma cell and exposed to ${ }^{60} \mathrm{Co}$ at a dose rate of $6.0 \mathrm{E} 5 \mathrm{R} / \mathrm{hr}$ for 21 days. The bottle was then removed and weighed to confirm only minor weight losses due to radiolysis or evaporation. The weight $\%$ solids results for the simulant before and after irradiation are shown in Table 3-1. The solids results confirm that only minor losses of water occurred during the irradiation. A small increase in insoluble solids was also indicated.

Table 3-1 Physical Properties of the Irradiated Simulant

\begin{tabular}{|c|c|c|}
\hline Results & Unirradiated Simulant & Irradiated Simulant \\
\hline Wt \% Total Solids & 15.04 & 15.10 \\
\hline Wt \% Soluble Solids & 7.57 & 7.24 \\
\hline Wt \% Insoluble Solids & 7.47 & 7.87 \\
\hline $\begin{array}{c}\text { Wt \% Dissolved Solids in } \\
\text { Supernate }\end{array}$ & 8.19 & 7.86 \\
\hline
\end{tabular}

Samples of the SB3 sludge simulant (before and after irradiation) were submitted to Analytical Development for particle size analysis by a light scattering technique. The mean particle size results are shown in Table 3-2. The mean particle size results suggest a shift to slightly smaller particle sizes on both a volume and a number basis. However, an examination of the overall particle size distribution on both a volume and a number basis (shown in Figure 3-1 and Figure 3-2) suggest that only a minor shift to smaller particles has occurred. The particle size distribution based on volume shows that the primary mode does not change due to the application of radiation. 
Table 3-2 Particle Size Results for Irradiated Sludge Simulant

\begin{tabular}{|c|c|c|c|}
\hline Measurement & Units & $\begin{array}{c}\text { Initial } \\
\text { Sludge }\end{array}$ & $\begin{array}{c}\text { Irradiated } \\
\text { Sludge }\end{array}$ \\
\hline Mean - Volume & microns & 32.7 & 27.8 \\
\hline Mean - Number & microns & 1.8 & 1.4 \\
\hline Mean - Area & microns & 9.2 & 8.5 \\
\hline CSSA & $\mathrm{m}^{2} / \mathrm{cm}^{3}$ & 0.7 & 0.7 \\
\hline
\end{tabular}

CSSA is the Calculated Specific Surface Area

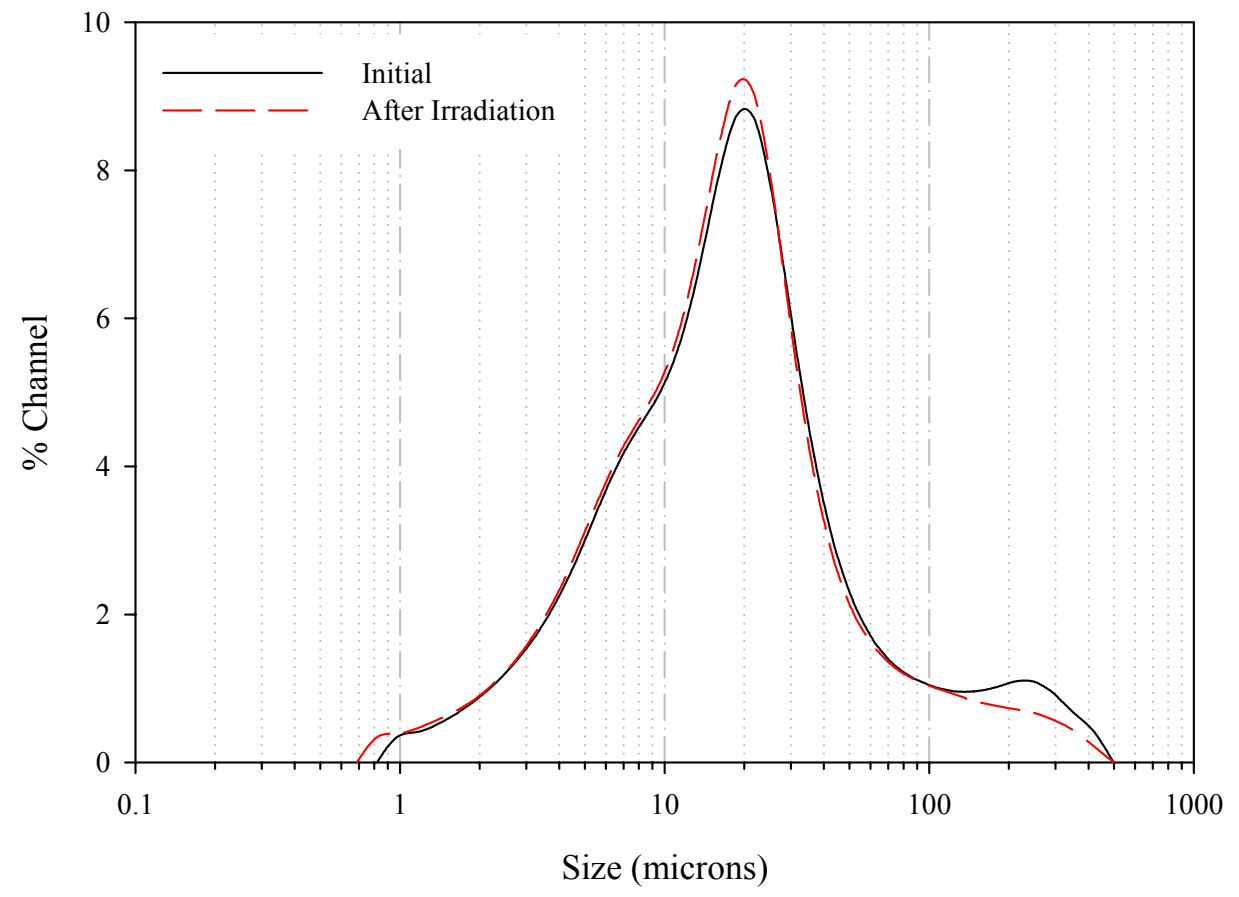

Figure 3-1 Impact of Irradiation on the Particle Size Distribution on a Volume Basis 
WSRC-TR-2005-00543

Revision 0

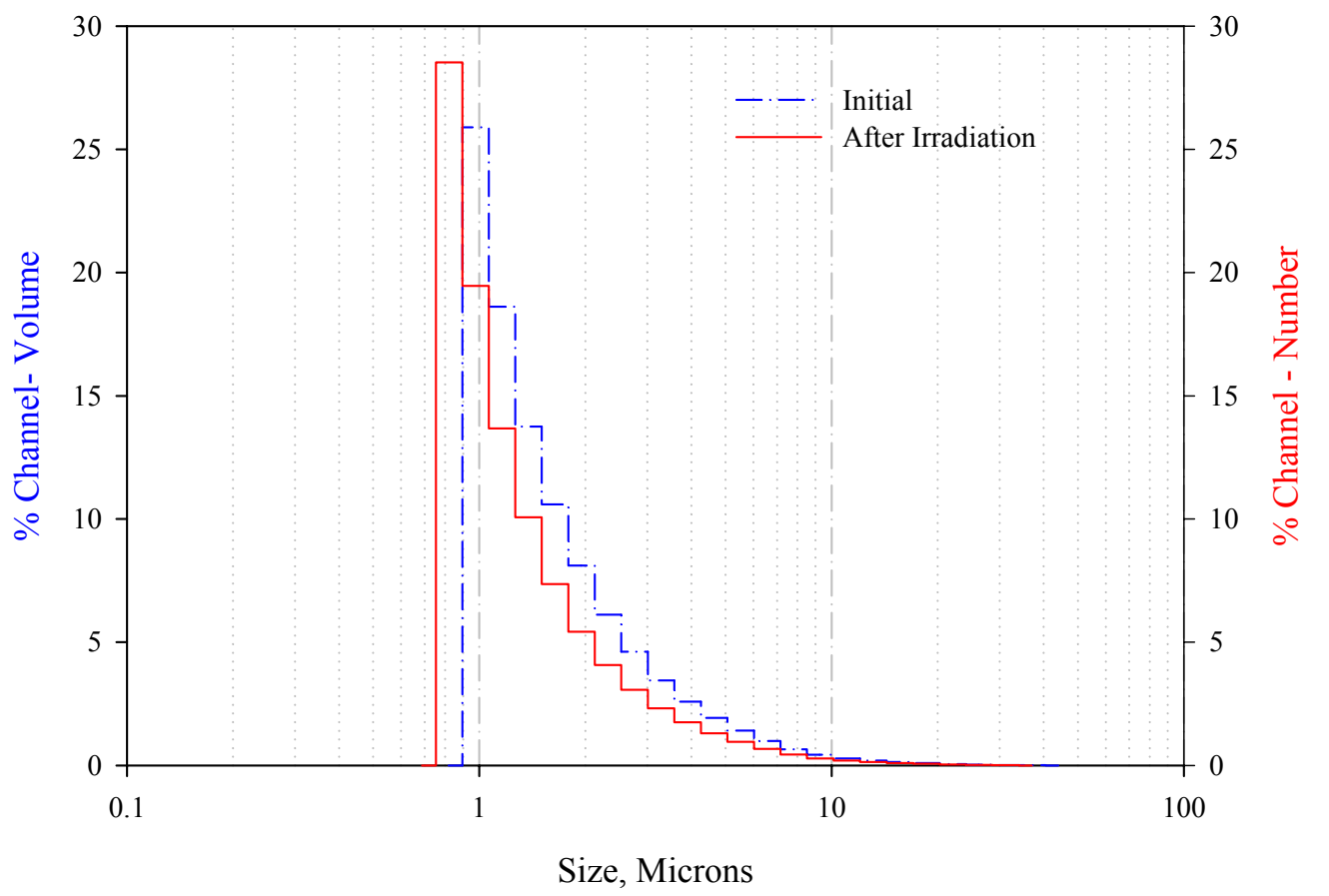

Figure 3-2 Impact of Irradiation on the Number-Based Particle Size Distribution

The rheology for the SB3 simulant was measured on unirradiated and irradiated samples at $25^{\circ} \mathrm{C}$ as described in section 2.4.2. Typical flow curves for the samples are shown in Figure 3-3. The flow curves do not show any evidence of thixotropic properties for these samples. The flow curves were evaluated using the Bingham plastic rheology model. The flow curves were fit to the Bingham equation over the shear rate range of 50 to $600 \mathrm{sec}^{-1}$ to produce the yield stress and consistency results reported in Table 3-3. The rheology data does not show any significant difference between the unirradiated and irradiated simulant for the conditions tested. 
WSRC-TR-2005-00543

Revision 0

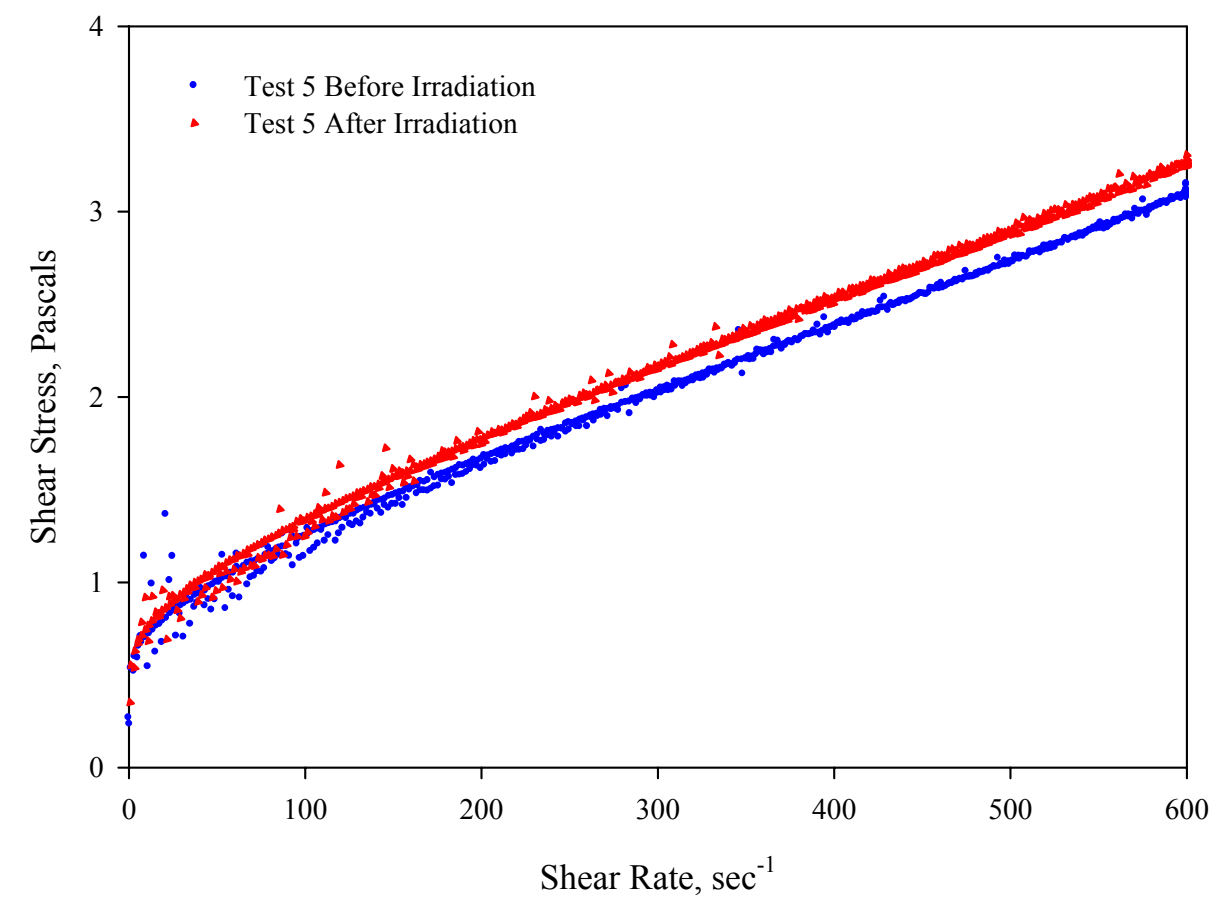

Figure 3-3 Flow Curves of SB3 Sludge Simulant before and after Irradiation

Table 3-3 Bingham Rheology Model Results for SB3 Sludge Simulant Impacted by Irradiation

\begin{tabular}{|c|c|c|c|c|}
\hline Irradiation & $\begin{array}{c}\text { Up Flow } \\
\text { Curve } \\
\text { Yield Stress, } \\
\text { Pascals }\end{array}$ & $\begin{array}{c}\text { Up Flow } \\
\text { Curve } \\
\text { Consistency, } \\
\text { Centipoise }\end{array}$ & $\begin{array}{c}\text { Down Flow } \\
\text { Curve } \\
\text { Yield Stress, } \\
\text { Pascals }\end{array}$ & $\begin{array}{c}\text { Down Flow } \\
\text { Curve } \\
\text { Consistency, } \\
\text { Centipoise }\end{array}$ \\
\hline Before & 1.08 & 3.5 & 0.94 & 3.8 \\
\hline Before & 0.85 & 3.8 & 0.91 & 3.7 \\
\hline After & 0.96 & 3.9 & 0.98 & 3.8 \\
\hline After & 0.94 & 4.0 & 0.98 & 3.8 \\
\hline
\end{tabular}

Radiation can produce electronic configuration changes within solids, which can lead to chemical reactions or recystallizations to produce different phases within the solids. Radiation can also generate reactions at surfaces between species in the aqueous phase and species on the surface. X-ray diffraction analysis can be used to examine the solids for evidence of such changes. Samples of the original simulant and of the irradiated simulant were analyzed by AD by XRD for the presence of identifiable phases within the insoluble solids. Figure 3-4 and Figure 3-5 show the results of XRD analysis for these samples. As expected, the alumina and silica added to the simulant during preparation were detected. The presence of an iron hydroxide species was also established. Comparison between the two patterns confirms that no major changes in the detectable crystalline materials due to the irradiation could be observed within this test. 


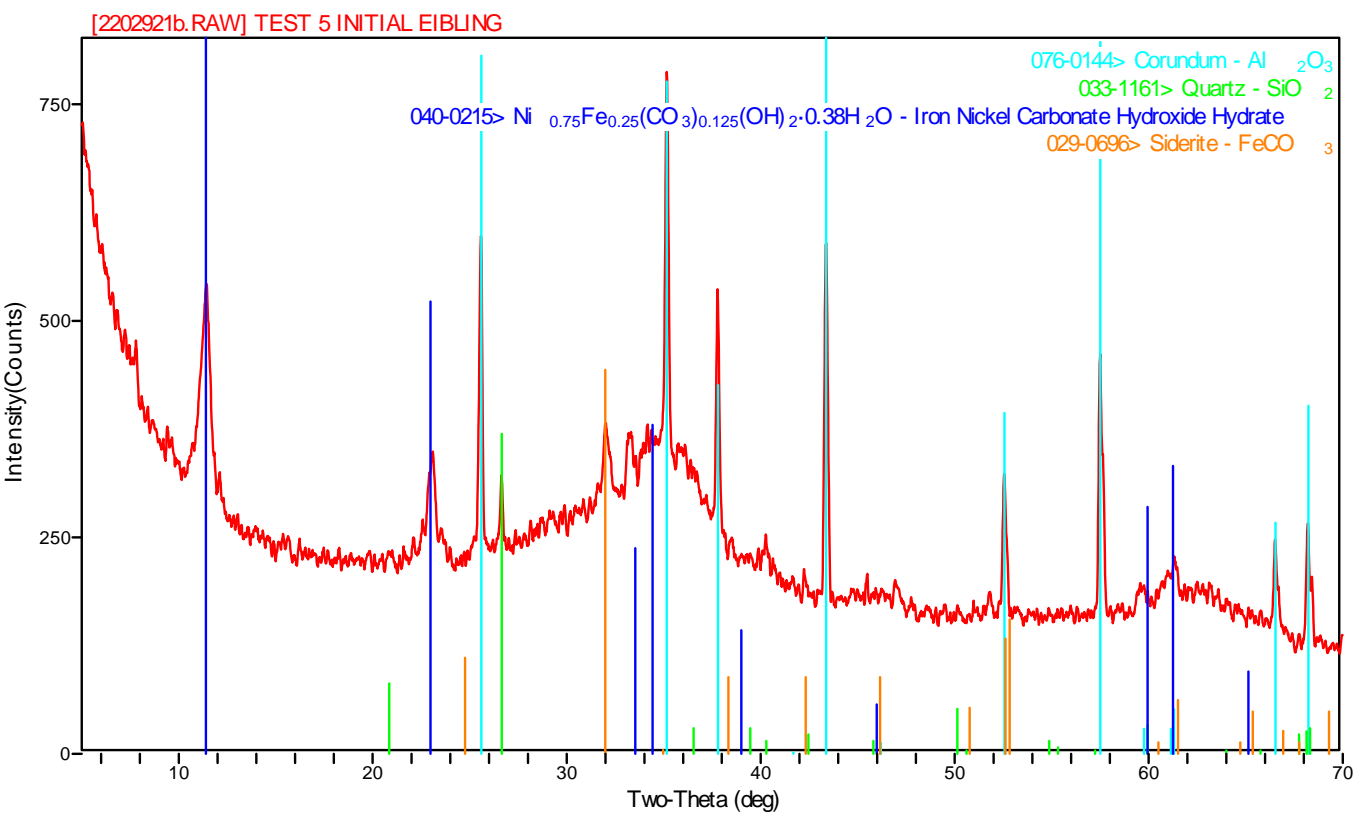

Figure 3-4 X-Ray Diffraction Analysis of the initial Sludge Simulant

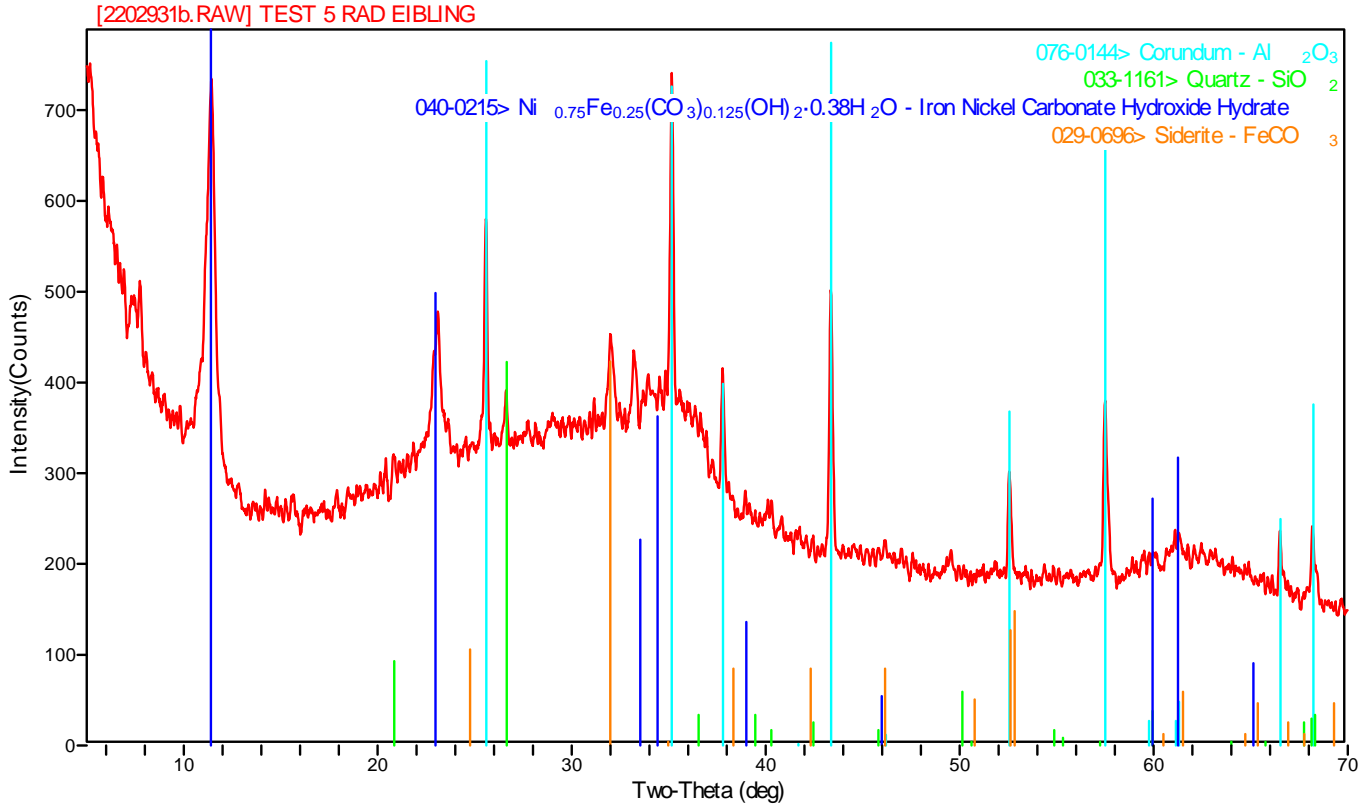

Figure 3-5 X-Ray Diffraction Analysis of the Sludge Simulant after Irradiation

The application of short-term radiation to the production of an improved SB3 simulant is not warranted based upon the observed lack of change in physical properties and in the detectable phases within the SB3 
sludge simulant during this study. However, this conclusion should not be extended to concluding that radiation does not affect high-level waste sludge in general. The slower application of radiation over a much longer period of time (decades instead of hours) might be more likely to induce changes due to much slower kinetic processes such as dissolution-recrystallization.

\subsection{Gravity-Washed SB3 Sludge Simulant Properties}

Prior simulant development research concluded that an improved DWPF sludge simulant that better matched actual waste physical properties could be prepared by coprecipitating aluminum, iron and all of the other transition metals. Additional improvement in physical properties was also obtained if the sludge simulant was aged by raising the temperature of the sludge for an additional period. A new batch of SB3 simulant produced by the recommended method from the FY2004 testing was prepared to allow additional tests on accelerated aging by thermal processing. The target batch size for the FY2005 SB3 sludge simulant was 10 liters and the sludge was produced as described in Section 2.3 using gravity washing to remove the excess nitrate anion. During gravity washing, the settled solids level did not settle to higher than 6-7 wt \% insoluble solids. Therefore, the volume of simulant produced was about 23.8 liters. The solids values for the gravity-washed SB3 simulant are shown in Table 3-4. For the purposes of identifying the larger bath of SB3 simulant, it will be identified in subsequent graphs as the "GravityWashed 10 Liter Batch".

Table 3-4 Gravity-Washed SB3 Sludge Simulant Product

\begin{tabular}{|c|c|c|}
\cline { 2 - 3 } \multicolumn{1}{c|}{} & Target & Product \\
\hline Volume, Liters & 10 & 23.8 \\
\hline Density, g/mL & 1.19 & 1.108 \\
\hline Wt \% Total Solids & 20.0 & 13.85 \\
\hline Wt \% Soluble Solids & 7.7 & 7.64 \\
\hline $\begin{array}{c}\text { Wt \% Insoluble } \\
\text { Solids }\end{array}$ & 12.3 & 6.21 \\
\hline
\end{tabular}

The particle size distribution was measured and is shown in Figure 3-6. The volume-based distribution is bimodal with the primary mode centered at 30 microns and the secondary mode at 8 microns. The number based distribution is unimodal with largest number of particles less than one micron. The mean particle sizes for the gravity-washed simulant are shown in Table 3-5. The large batch of SB3 simulant has a larger average particle size on a volume basis and a smaller average size on number basis than the FY2004 simulant

Table 3-5 Particle Size Results for Gravity-Washed Sludge Simulant

\begin{tabular}{|c|c|c|c|}
\hline Measurement & Units & $\begin{array}{c}\text { 10 Liter } \\
\text { Batch }\end{array}$ & $\begin{array}{c}\text { 2 Liter } \\
\text { Batch }\end{array}$ \\
\hline $\begin{array}{c}\text { Mean - } \\
\text { Volume }\end{array}$ & microns & 23.9 & 19.7 \\
\hline $\begin{array}{c}\text { Mean - } \\
\text { Number }\end{array}$ & microns & 1.44 & 2.05 \\
\hline Mean - Area & microns & 8.02 & 9.09 \\
\hline CSSA & $\mathrm{m}^{2} / \mathrm{cm}^{3}$ & 0.75 & 0.66 \\
\hline
\end{tabular}


WSRC-TR-2005-00543

Revision 0

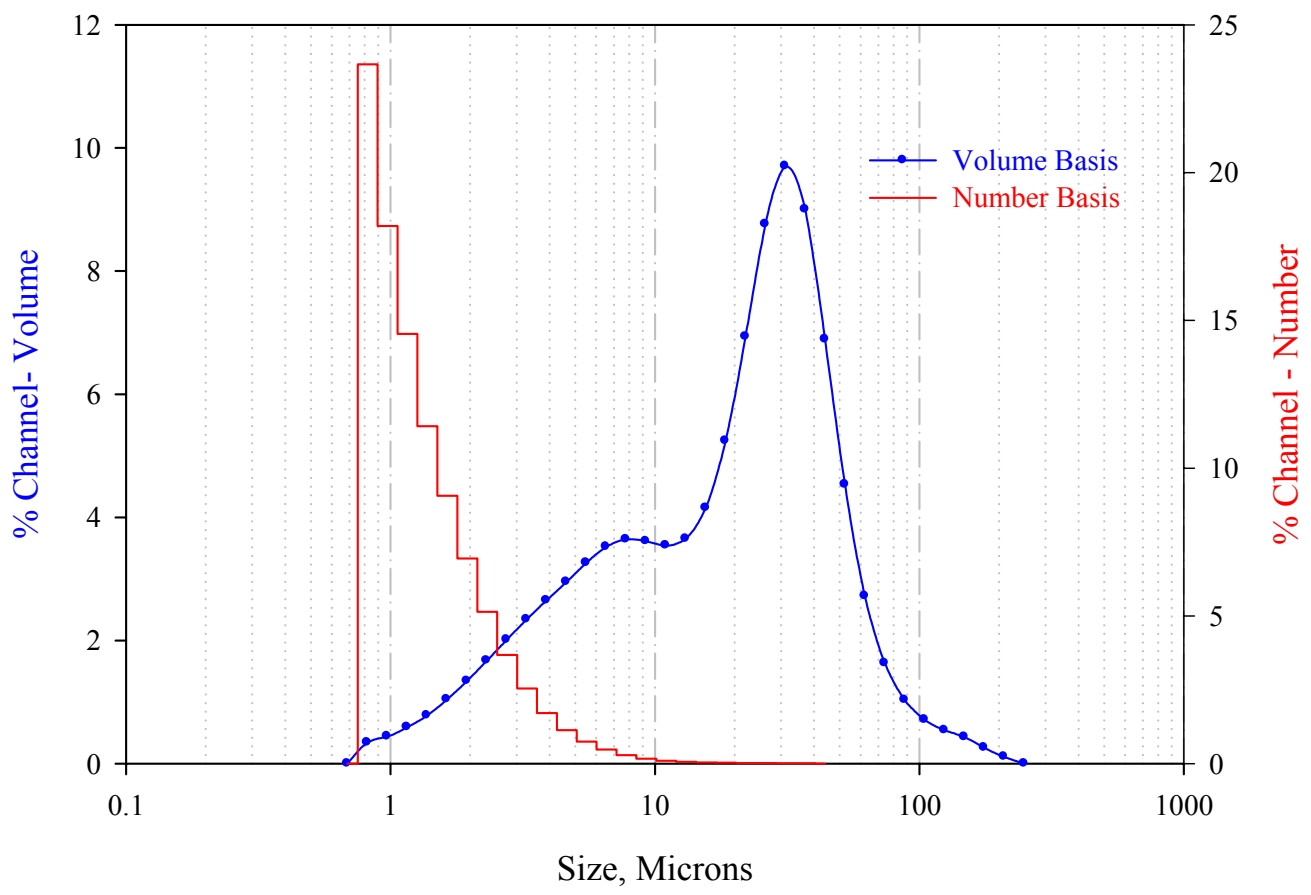

Figure 3-6 Particle Size Results for the 10 Liter Batch of Gravity-Washed SB3 Sludge Simulant

Figure 3-7 and Figure 3-8 compare the particle size distributions for the "10 Liter Batch" to the FY2004 simulant that was prepared by the same procedure but on a smaller scale. The volume-based distribution does show a broader distribution of sizes which is also bimodal as was the smaller batch size from the prior year. However, the maxima in both modes have shifted to a larger particle size generating, therefore, a larger average particle size based on volume. The number based distribution indicates that a shift to smaller particle sizes also occurred in the larger batch size simulant. 
Revision 0

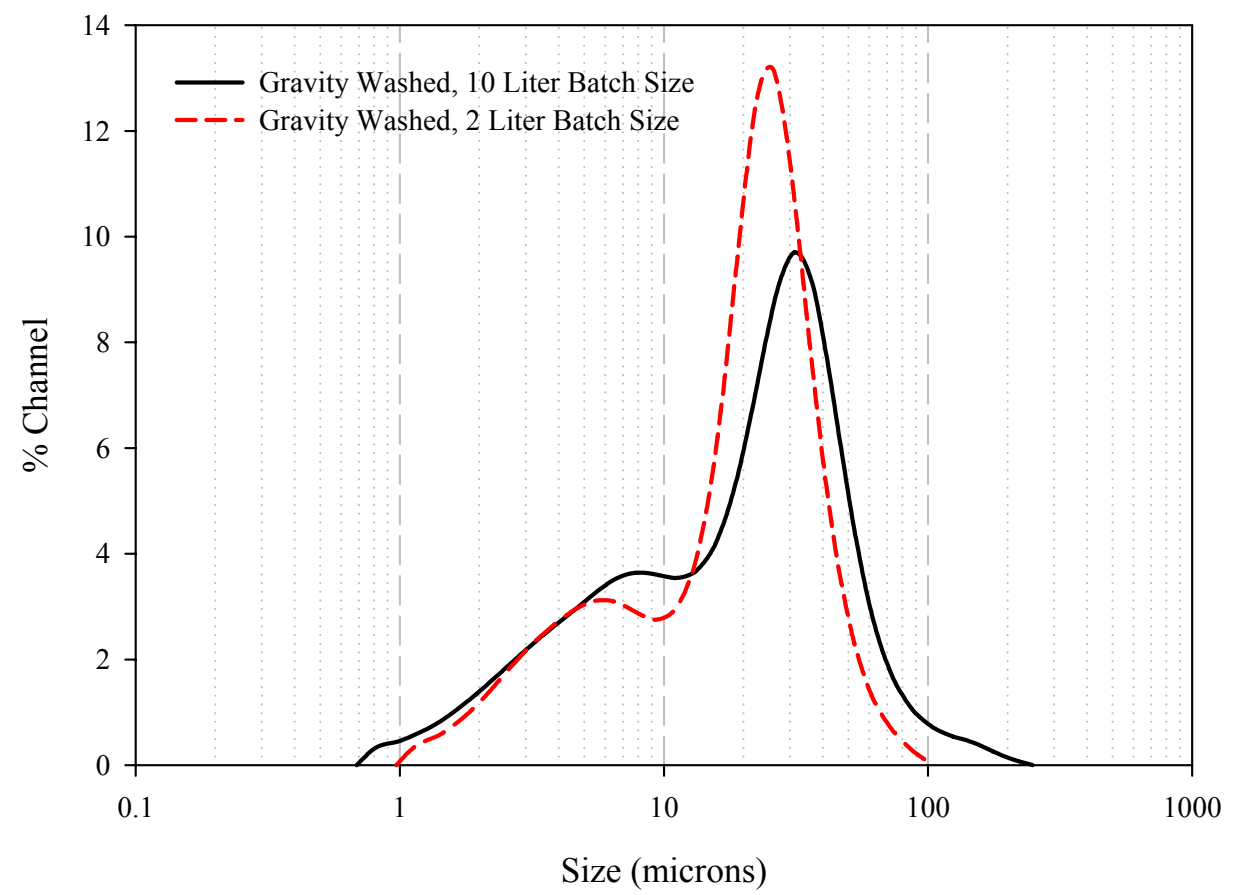

Figure 3-7 Comparison of Particle Size Distributions (Volume Basis) for Gravity-Washed SB3 Sludge Simulants

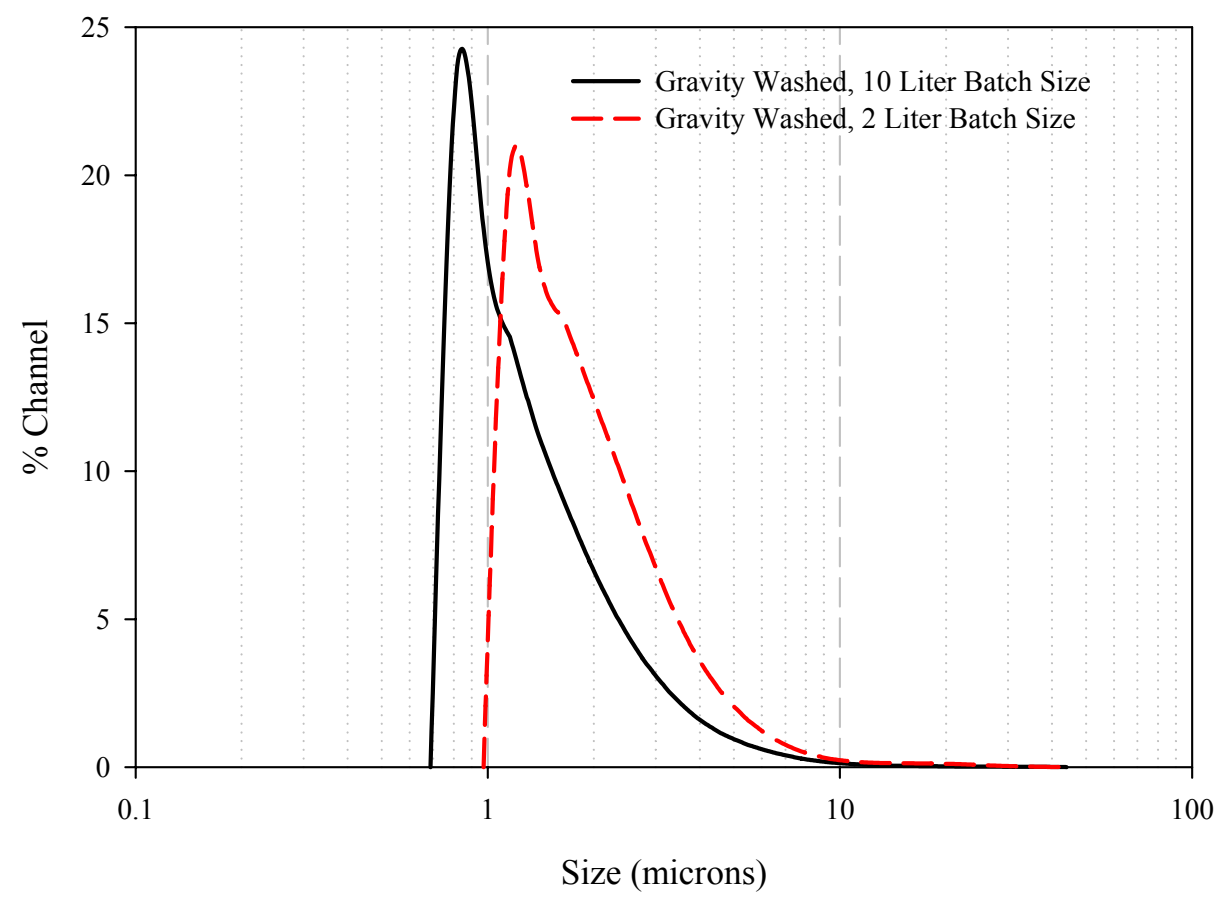

Figure 3-8 Comparison of Particle Size Distributions (Number Basis) for Gravity-Washed SB3 Sludge Simulants 
The rheology of the gravity-washed SB3 simulant was measured as a function of the insoluble solids content and a fixed supernate composition. The higher concentrations of insoluble solids in the simulant were prepared by centrifuging the simulant, decanting a portion of the supernate and resuspending the solids. The centrifuge was used due to the excessive time required for settling to achieve the same insoluble solids results. The concentration procedure was similar to that used during the FY2004 simulant study. A 600 gram sample of the simulant was centrifuged at $1500 \mathrm{rpm}$ for 20 minutes in a IEC Centra-GP8 centrifuge. A portion of the supernate was removed and the insoluble solids were resuspended by violent shaking for two to five minutes. The concentrated samples were then probed with a spatula to verify the absence of a dense phase in the samples. The samples were analyzed for the solids content as described in Section 2.4.1 and for rheology as described in Section 2.4.2.

The Bingham yield stress and consistency results for the gravity-washed SB3 sludge simulant are shown in Table 3-6. The table shows that at the higher levels of insoluble solids, the down curve was above the up curve. While this could indicate a rheopectic (shear thickening) slurry, the shape of the down flow curve does not suggest such a rheological property. Prior SB3 simulants showed shear thinning properties instead when measured with the cylindrical bob and cup geometry. In this study, the measurements were made with the cone and plate geometry that can be susceptible to drying at the outer edge of the cone sensor. No effort was made during this study to prevent drying other than avoiding long durations for the shearing times. Therefore, the yield stress and consistency results will be taken from the up flow curves for these simulants.

Table 3-6 Rheology of Gravity-Washed SB3 Sludge Simulant

\begin{tabular}{|c|c|c|c|c|c|c|c|}
\hline \multirow{2}{*}{$\begin{array}{c}\text { Insoluble } \\
\text { Solids, } \\
\text { wt \% }\end{array}$} & $\begin{array}{c}\text { Total } \\
\text { Solids, } \\
\text { wt \% }\end{array}$ & $\begin{array}{c}\text { Yield } \\
\text { Stress, } \\
\text { Pa }\end{array}$ & $\begin{array}{c}\text { Yield } \\
\text { Stress, } \\
\text { dynes/cm }\end{array}$ & $\begin{array}{c}\text { Consistency, } \\
\mathbf{c P}\end{array}$ & $\begin{array}{c}\text { Yield } \\
\text { Stress, } \\
\text { Pa }\end{array}$ & $\begin{array}{c}\text { Yield } \\
\text { Stress, } \\
\text { dynes/cm }\end{array}$ & $\begin{array}{c}\text { Consistency, } \\
\text { cP }\end{array}$ \\
\hline 6.21 & 13.8 & 0.72 & 7.2 & 3.93 & 0.75 & 7.5 & 3.92 \\
\hline 6.21 & 13.8 & 0.68 & 6.8 & 4.02 & 0.74 & 7.4 & 3.93 \\
\hline 7.12 & 14.7 & 1.58 & 15.8 & 5.22 & 1.58 & 15.8 & 5.26 \\
\hline 7.12 & 14.7 & 1.48 & 14.8 & 5.03 & 1.47 & 14.7 & 5.08 \\
\hline 8.78 & 16.2 & 3.77 & 37.7 & 7.81 & 3.9 & 39 & 7.79 \\
\hline 8.78 & 16.2 & 3.75 & 37.5 & 7.86 & 3.9 & 39 & 7.81 \\
\hline 10.4 & 17.7 & 10.3 & 103 & 14.2 & 11.8 & 118 & 12.9 \\
\hline 10.4 & 17.7 & 10.2 & 102 & 14.4 & 11.9 & 119 & 12.9 \\
\hline 12.5 & 19.7 & 25.5 & 255 & 29.0 & 27.6 & 276 & 28.4 \\
\hline 12.5 & 19.7 & 25.4 & 254 & 29.1 & 27.7 & 277 & 28.0 \\
\hline
\end{tabular}

The yield stress and consistency results for the up flow curves were fitted using TableCurve ${ }^{\circledR} 2 \mathrm{D}$ to an equation of the following form:

$$
Y=\frac{e^{A X}}{1-X / B}-C
$$

where $\mathrm{Y}$ is either yield stress or consistency, $\mathrm{X}$ is wt \% insoluble solids, and $\mathrm{A}, \mathrm{B}$ and $\mathrm{C}$ are adjustable parameters (note: that $\mathrm{B}$ is constrained to be between 0 and 100). This equation is of the same form as 
that used in prior rheology studies with an additional parameter to allow better fits at very low solids contents. $^{2}$ Figure 3-9 and Figure 3-10 display the data and the corresponding curve generated from the data for the current gravity-washed SB3 simulant (ten-liter batch) and for the prior year simulant studies. The current batch of gravity-washed SB3 simulant has considerably higher yield stress values than the prior batch for any solids concentration greater than about $9 \mathrm{wt} \%$ insoluble solids despite being produced from the same recipe basis. The consistency of the current batch is also larger (but not quite as severely) than the previous batch. The only significant difference between the batches of SB3 simulant was the scale at which the simulant was being prepared. Future simulant development should focus on identifying and controlling those factors that are scale dependent so that larger batches of a simulant will match the desired rheology.

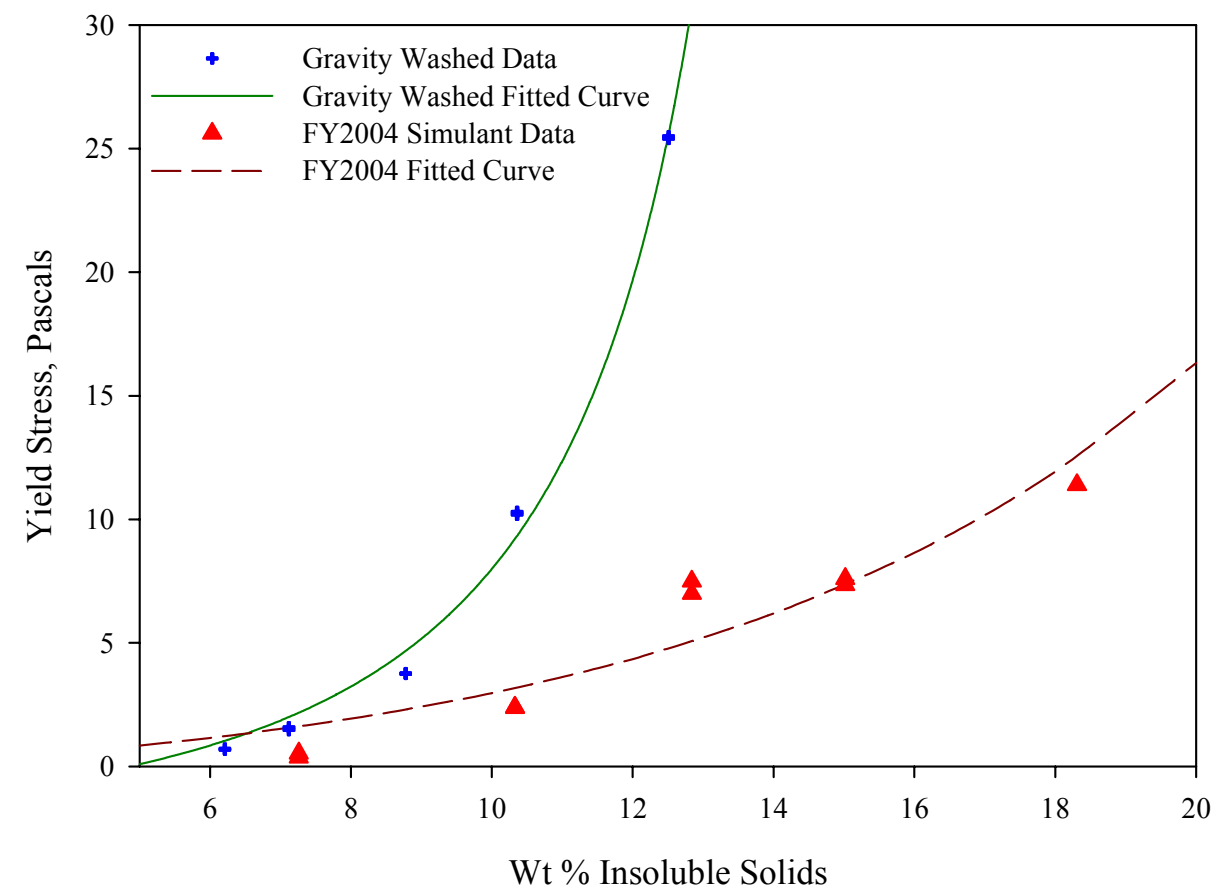

Figure 3-9 Yield Stress as a Function of Insoluble Solids for the Initial Gravity-Washed Sludge Simulant 


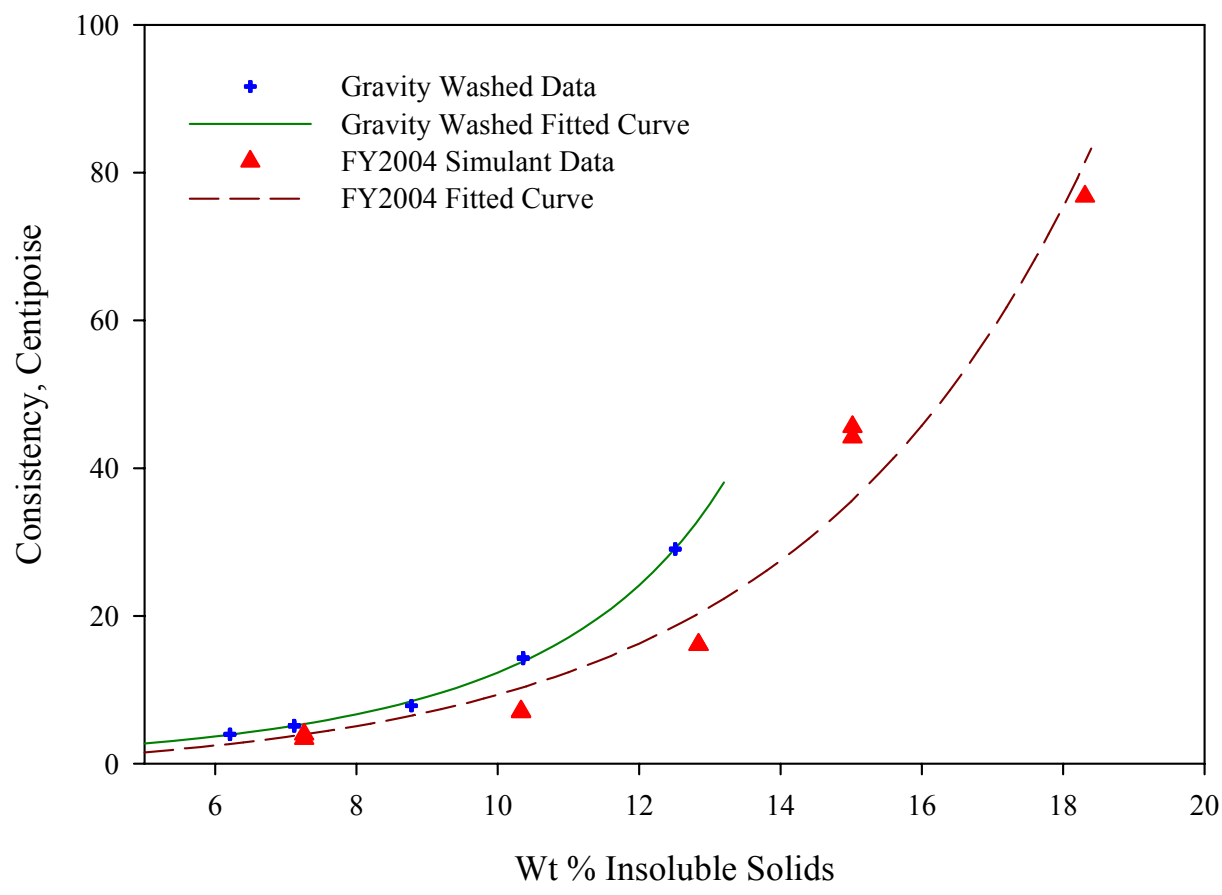

Figure 3-10 Consistency as a Function of Insoluble Solids for the Initial Gravity-Washed Sludge Simulant

\subsection{Thermally Aged, Gravity-Washed SB3 Sludge Simulant}

Freshly precipitated transition metal hydroxides (such as $\mathrm{Fe}, \mathrm{Ni}$, etc.) are generally amorphous materials with practically no defined crystalline characteristics. Over time, these precipitates can convert to more crystalline compounds. This aging process is expected to occur in HLW sludge and in sludge simulants. Elevated temperatures can accelerate the recrystallization. Prior simulant development tests demonstrated that accelerated aging by heating the simulant could improve the rheology of the simulant. A significant modification in the physical properties of a Hanford precipitated simulant was obtained by boiling the simulant to concentrate the insoluble solids. ${ }^{1}$ Much smaller property changes were observed in prior DWPF simulant when the precipitated simulant was heated to $98^{\circ} \mathrm{C}$ for 8 hours. ${ }^{2}$ Therefore, additional tests were planned on the application of thermal treatment to accelerate the aging of a DWPF simulant.

Accelerated aging by thermal treatment tests for the gravity-washed SB3 simulant were planned at $90{ }^{\circ} \mathrm{C}$ and boiling conditions. Tested heating durations were 8, 16 and 32 hours for the $90^{\circ} \mathrm{C}$ tests (tests $9-\mathrm{H} 1$, 9-H2, and 9-H5) and 8 and 16 hours for the boiling tests (tests 9-H3 and 9-H4). The heat treatment tests were performed in a 4 liter glass reaction kettle ( 5 inch diameter by 13 inch tall) equipped with a condenser cooled to $10^{\circ} \mathrm{C}$ mounted in reflux mode. Agitation was provided by a high shear, Rushton radial flow impeller ( 3.5 inch diameter) with a 4 blade, 45 degree turbine impeller ( 3.5 inch diameter) mounted above. Agitation speed was 300 revolutions per minute (rpm). Three thousand five hundred grams of gravity-washed SB3 simulant were thermally aged for each temperature-time combination to provide sufficient material to determine the rheology as a function of the solids content (as previously described).

Samples of the heat-treated simulants were submitted for XRD to determine if compositional changes due to the accelerated aging process could be identified. Compositional changes were detected in the 
samples. Figure 3-11 and Figure 3-12 show the before and after XRD results for the SB3 simulant after 16 hours of boiling.

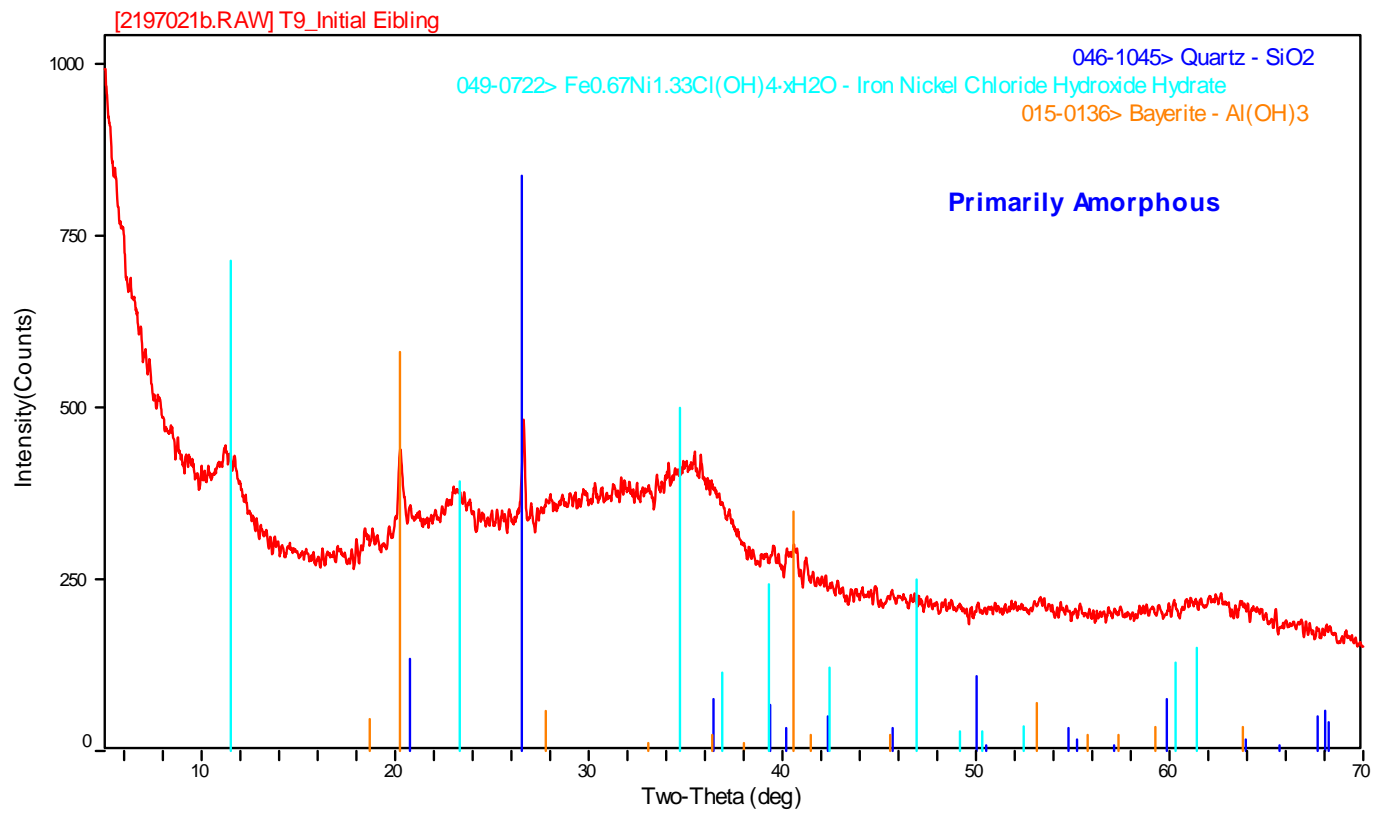

Figure 3-11 X-Ray Diffraction Analysis of the Gravity-Washed SB3 Sludge Simulant 


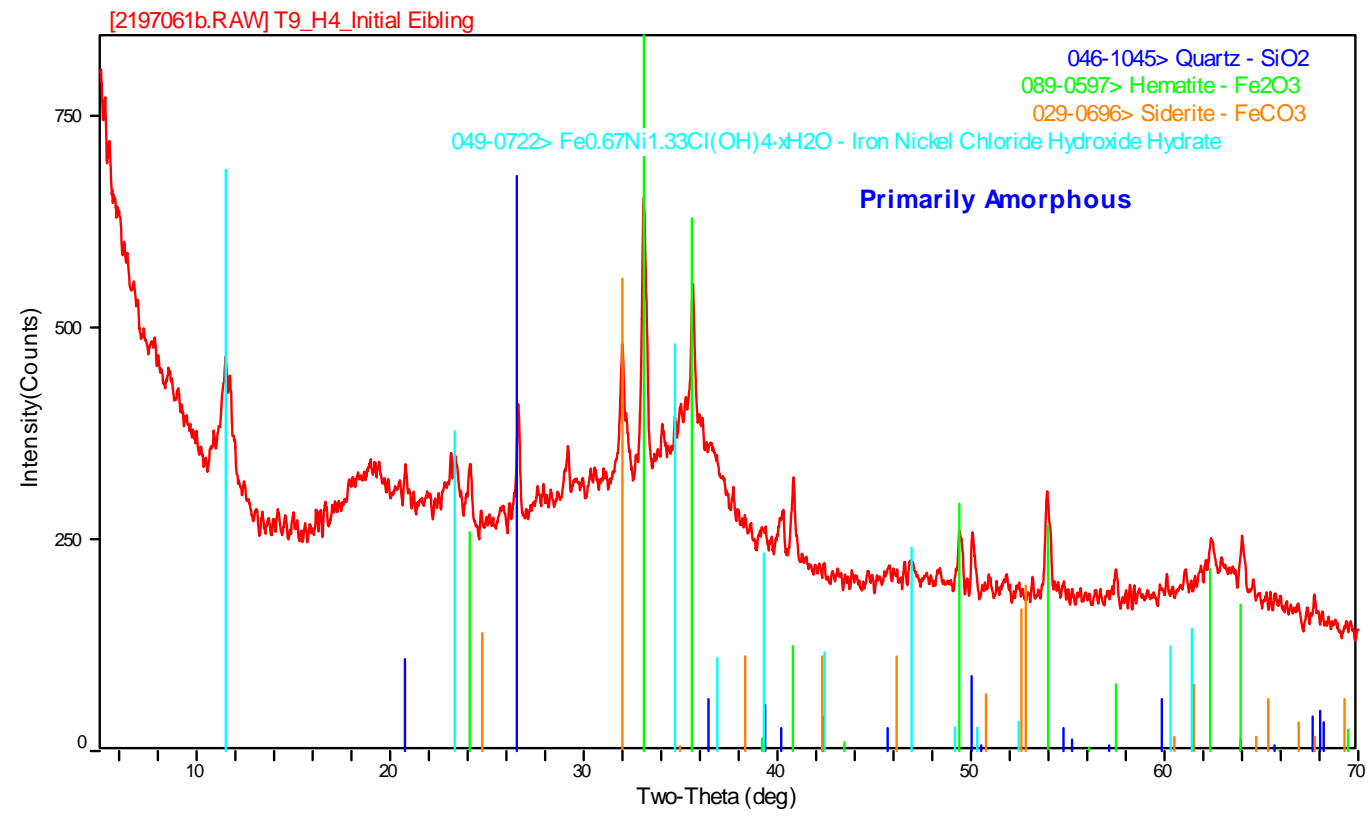

\section{Figure 3-12 X-Ray Diffraction Analysis of the Gravity-Washed SB3 Sludge Simulant after Accelerated Aging (16 Hours Boiling)}

The XRD analysis result that both samples are primarily amorphous was expected. However, changes in the identified compounds did occur. The conversion of some of the amorphous iron hydroxide to hematite $\left(\mathrm{Fe}_{2} \mathrm{O}_{3}\right)$ demonstrates that modification of the simulant does take place as a result of the storage time at elevated temperatures. The current XRD information is not sufficient to determine if the degree of modification is capable of changing the physical properties of the simulant.

Samples of the heat-treated test products were prepared at different insoluble solids contents as previously described and the rheology measured for each sample. Table 3-7, Table 3-8 and Table 3-9 show the results of applying the Bingham rheology model to the results for the samples from the $90{ }^{\circ} \mathrm{C}$ aging experiments. As before, the up flow curves were below the down flow curves. 
Table 3-7 Rheology Results for the Gravity-Washed Sludge Simulant after Accelerated Aging for 8 Hours at $90{ }^{\circ} \mathrm{C}$

\begin{tabular}{|c|c|c|c|c|c|c|c|}
\cline { 3 - 8 } \multicolumn{2}{c|}{} & \multicolumn{3}{c|}{ Up Flow Curve } & \multicolumn{3}{c|}{ Down Flow Curve } \\
\hline $\begin{array}{c}\text { Insoluble } \\
\text { Solids, } \\
\text { wt \% }\end{array}$ & $\begin{array}{c}\text { Total } \\
\text { Solids, } \\
\text { wt \% }\end{array}$ & $\begin{array}{c}\text { Yield } \\
\text { Stress, } \\
\text { Pascal }\end{array}$ & $\begin{array}{c}\text { Yield } \\
\text { Stress, } \\
\text { dynes/cm }\end{array}$ & $\begin{array}{c}\text { Consistency, } \\
\text { cP }\end{array}$ & $\begin{array}{c}\text { Yield } \\
\text { Stress, } \\
\text { Pascal }\end{array}$ & $\begin{array}{c}\text { Yield } \\
\text { Stress, } \\
\text { dynes/cm }\end{array}$ & $\begin{array}{c}\text { Consistency, } \\
\text { cP }\end{array}$ \\
\hline 5.5 & 13.5 & 0.29 & 2.9 & 3.2 & 0.28 & 2.8 & 3.2 \\
\hline 5.5 & 13.5 & 0.36 & 3.6 & 3.1 & 0.36 & 3.6 & 3 \\
\hline 7.88 & 15.6 & 1.77 & 17.7 & 5.8 & 2.2 & 22 & 5.2 \\
\hline 7.88 & 15.6 & 1.78 & 17.8 & 5.8 & 2.24 & 22.4 & 5.2 \\
\hline 9.98 & 17.6 & 6.40 & 64.0 & 12.4 & 10.11 & 101.1 & 7.9 \\
\hline 9.98 & 17.56 & 6.43 & 64.3 & 12.6 & 10.12 & 101.2 & 8.1 \\
\hline 12.7 & 20.0 & 19.0 & 190 & 41.2 & 37.5 & 375 & 21.1 \\
\hline 12.7 & 20.0 & 19.9 & 199 & 41.9 & 38.1 & 381 & 21.8 \\
\hline 15.8 & 22.9 & 78.1 & 781 & 90.7 & 87.0 & 870 & 83.2 \\
\hline 15.8 & 22.9 & 73.4 & 734 & 80.3 & 82.9 & 829 & 74.6 \\
\hline
\end{tabular}

Table 3-8 Rheology Results for the Gravity-Washed Sludge Simulant after Accelerated Aging for 16 Hours at $90^{\circ} \mathrm{C}$

\begin{tabular}{|c|c|c|c|c|c|c|c|}
\cline { 3 - 8 } \multicolumn{2}{c|}{} & \multicolumn{3}{c|}{ Up Flow Curve } & \multicolumn{2}{c|}{ Down Flow Curve } \\
\hline $\begin{array}{c}\text { Insoluble } \\
\text { Solids, } \\
\text { wt \% }\end{array}$ & $\begin{array}{c}\text { Total } \\
\text { Solids, } \\
\text { wt \% }\end{array}$ & $\begin{array}{c}\text { Yield } \\
\text { Stress, } \\
\text { Pascal }\end{array}$ & $\begin{array}{c}\text { Yield } \\
\text { Stress, } \\
\text { dynes/cm }\end{array}$ & $\begin{array}{c}\text { Consistency, } \\
\text { cP }\end{array}$ & $\begin{array}{c}\text { Yield } \\
\text { Stress, } \\
\text { Pascal }\end{array}$ & $\begin{array}{c}\text { Yield } \\
\text { Stress, } \\
\text { dynes/cm }\end{array}$ & $\begin{array}{c}\text { Consistency, } \\
\text { cP }\end{array}$ \\
\hline 5.39 & 13.3 & 0.24 & 2.4 & 3 & 0.29 & 2.9 & 2.9 \\
\hline 5.39 & 13.3 & 0.25 & 2.5 & 3 & 0.3 & 3 & 2.9 \\
\hline 7.97 & 15.7 & 1.88 & 18.8 & 5.8 & 2.39 & 23.9 & 5.2 \\
\hline 7.97 & 15.7 & 1.88 & 18.8 & 5.9 & 2.43 & 24.3 & 5.2 \\
\hline 10.4 & 17.8 & 5.61 & 56.1 & 12.4 & 9.68 & 96.8 & 7.4 \\
\hline 10.4 & 17.8 & 5.64 & 56.4 & 12.4 & 9.74 & 97.4 & 7.4 \\
\hline 12.7 & 20.0 & 21.3 & 213 & 41.6 & 36.3 & 363 & 27.2 \\
\hline 12.7 & 20.0 & 21.8 & 218 & 43.4 & 38.1 & 381 & 27 \\
\hline 16.7 & 23.7 & 74.9 & 749 & 91.21 & 73.3 & 733 & 118.2 \\
\hline 16.7 & 23.7 & 74.0 & 740 & 84.9 & 72.9 & 729 & 108.2 \\
\hline
\end{tabular}


Table 3-9 Rheology Results for the Gravity-Washed Sludge Simulant after Accelerated Aging for 32 Hours at $90{ }^{\circ} \mathrm{C}$

\begin{tabular}{|c|c|c|c|c|c|c|c|}
\cline { 3 - 8 } \multicolumn{2}{c|}{} & \multicolumn{3}{c|}{ Up Flow Curve } & \multicolumn{3}{c|}{ Down Flow Curve } \\
\hline $\begin{array}{c}\text { Insoluble } \\
\text { Solids, } \\
\text { wt \% }\end{array}$ & $\begin{array}{c}\text { Total } \\
\text { Solids, } \\
\text { wt \% }\end{array}$ & $\begin{array}{c}\text { Yield } \\
\text { Stress, } \\
\text { Pascal }\end{array}$ & $\begin{array}{c}\text { Yield } \\
\text { Stress, } \\
\text { dynes/cm }\end{array}$ & $\begin{array}{c}\text { Consistency, } \\
\text { cP }\end{array}$ & $\begin{array}{c}\text { Yield } \\
\text { Stress, } \\
\text { Pascal }\end{array}$ & $\begin{array}{c}\text { Yield } \\
\text { Stress, } \\
\text { dynes/cm }\end{array}$ & $\begin{array}{c}\text { Consistency, } \\
\text { cP }\end{array}$ \\
\hline 5.31 & 13.3 & 0.22 & 2.2 & 2.89 & 0.26 & 2.6 & 2.81 \\
\hline 5.31 & 13.3 & 0.21 & 2.1 & 2.89 & 0.26 & 2.6 & 2.81 \\
\hline 8.07 & 15.8 & 1.53 & 15.3 & 5.4 & 1.97 & 19.7 & 4.84 \\
\hline 8.07 & 15.8 & 1.56 & 15.6 & 5.44 & 2.01 & 20.1 & 4.84 \\
\hline 10.4 & 17.9 & 5.13 & 51.3 & 11.7 & 9.24 & 92.4 & 6.84 \\
\hline 10.4 & 17.9 & 5.2 & 52 & 12.0 & 9.4 & 94 & 6.98 \\
\hline 12.6 & 20.0 & 15.3 & 153 & 46.2 & 39.9 & 399 & 23.9 \\
\hline 12.6 & 20.0 & 16.2 & 162 & 44.5 & 38.9 & 389 & 23.7 \\
\hline 16.0 & 23.1 & 61.0 & 610 & 94.3 & 64.8 & 648 & 115.7 \\
\hline 16.0 & 23.1 & 68.3 & 683 & 98.5 & 72.8 & 728 & 123.4 \\
\hline
\end{tabular}

The Bingham yield stress results as a function of the insoluble solids content for each of the series of tests run at $90{ }^{\circ} \mathrm{C}$ is shown in Figure 3-13. There appears to be a general trend of reduction in the yield stress for the high insoluble solids levels for the heat-treated simulant. The reduction in yield stress suggests that even longer periods of elevated temperature might generate further improvement in the rheology of the simulant. The consistency for the $90{ }^{\circ} \mathrm{C}$ tests will be discussed later. 
WSRC-TR-2005-00543

Revision 0

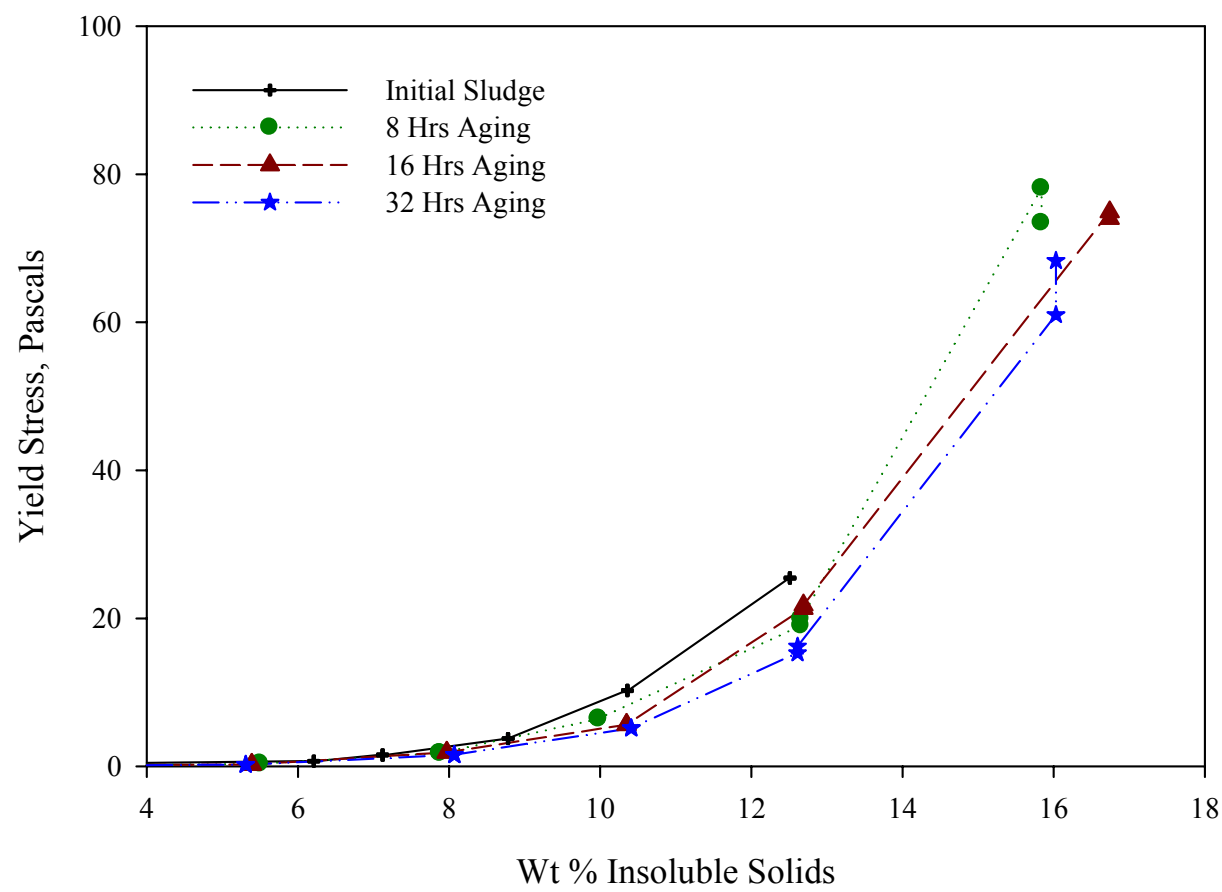

Figure 3-13 Impact of Accelerated Aging at $90^{\circ} \mathrm{C}$ on the Rheology of Gravity-Washed SB3 Simulant

Two test mixtures were prepared by accelerated aging at boiling $\left(101-2^{\circ} \mathrm{C}\right)$ conditions to determine if a higher, easily achievable temperature would increase the degree or rate of rheology modification for the SB3 simulant. The rheology samples for higher-temperature tests were prepared in the same manner as the lower temperature tests. Table 3-10 and Table 3-11 list the rheology results for the sludges aged by boiling. 
Table 3-10 Rheology Results for the Gravity-Washed Sludge Simulant after Accelerated Aging for 8 Hours at Boiling

\begin{tabular}{|c|c|c|c|c|c|c|c|}
\cline { 3 - 8 } \multicolumn{2}{c|}{} & \multicolumn{3}{c|}{ Up Flow Curve } & \multicolumn{2}{c|}{ Down Flow Curve } \\
\hline $\begin{array}{c}\text { Insoluble } \\
\text { Solids, } \\
\text { wt \% }\end{array}$ & $\begin{array}{c}\text { Total } \\
\text { Solids, } \\
\text { wt \% }\end{array}$ & $\begin{array}{c}\text { Yield } \\
\text { Stress, } \\
\text { Pascal }\end{array}$ & $\begin{array}{c}\text { Yield } \\
\text { Stress, } \\
\text { dynes/cm }\end{array}$ & $\begin{array}{c}\text { Consistency, } \\
\text { cP }\end{array}$ & $\begin{array}{c}\text { Yield } \\
\text { Stress, } \\
\text { Pascal }\end{array}$ & $\begin{array}{c}\text { Yield } \\
\text { Stress, } \\
\text { dynes/cm }\end{array}$ & $\begin{array}{c}\text { Consistency, } \\
\text { cP }\end{array}$ \\
\hline 5.45 & 13.4 & 0.26 & 2.6 & 3.11 & 0.33 & 3.3 & 2.97 \\
\hline 5.45 & 13.4 & 0.26 & 2.6 & 3.12 & 0.33 & 3.3 & 2.98 \\
\hline 8.25 & 16.0 & 2.19 & 21.9 & 6.3 & 2.78 & 27.8 & 5.53 \\
\hline 8.25 & 16.0 & 2.21 & 22.1 & 6.31 & 2.83 & 28.3 & 5.51 \\
\hline 10.3 & 17.8 & 7.57 & 75.7 & 13.9 & 12.5 & 125 & 8.11 \\
\hline 10.3 & 17.8 & 7.65 & 76.5 & 14.2 & 12.7 & 127 & 8.24 \\
\hline 13.1 & 20.4 & 22.65 & 226.5 & 45.6 & 41.2 & 412 & 28.5 \\
\hline 13.1 & 20.4 & 22.96 & 229.6 & 48.6 & 42.4 & 424 & 29.6 \\
\hline 15.7 & 22.8 & 78.7 & 787 & 93.5 & 63.7 & 637 & 138.4 \\
\hline 15.7 & 22.8 & 84.6 & 846 & 91.2 & 62.6 & 626 & 148 \\
\hline
\end{tabular}

Table 3-11 Rheology Results for the Gravity-Washed Sludge Simulant after Accelerated Aging for 16 Hours at Boiling

\begin{tabular}{|c|c|c|c|c|c|c|c|}
\cline { 3 - 8 } \multicolumn{2}{c|}{} & \multicolumn{3}{c|}{ Up Flow Curve } & \multicolumn{3}{c|}{ Down Flow Curve } \\
\hline $\begin{array}{c}\text { Insoluble } \\
\text { Solids, } \\
\text { wt \% }\end{array}$ & $\begin{array}{c}\text { Total } \\
\text { Solids, } \\
\text { wt \% }\end{array}$ & $\begin{array}{c}\text { Yield } \\
\text { Stress, } \\
\text { Pascal }\end{array}$ & $\begin{array}{c}\text { Yield } \\
\text { Stress, } \\
\text { dynes/cm }\end{array}$ & $\begin{array}{c}\text { Consistency, } \\
\text { cP }\end{array}$ & $\begin{array}{c}\text { Yield } \\
\text { Stress, } \\
\text { Pascal }\end{array}$ & $\begin{array}{c}\text { Yield } \\
\text { Stress, } \\
\text { dynes/cm }\end{array}$ & $\begin{array}{c}\text { Consistency, } \\
\text { cP }\end{array}$ \\
\hline 5.29 & 13.2 & 0.22 & 2.2 & 2.95 & 0.29 & 2.9 & 2.82 \\
\hline 5.29 & 13.2 & 0.23 & 2.3 & 2.98 & 0.29 & 2.9 & 2.86 \\
\hline 7.91 & 15.6 & 1.33 & 13.3 & 5.22 & 1.75 & 17.5 & 4.64 \\
\hline 7.91 & 15.6 & 1.53 & 15.3 & 5.72 & 2.05 & 20.5 & 5.00 \\
\hline 10.2 & 17.7 & 4.23 & 42.3 & 11.3 & 8.04 & 80.4 & 6.74 \\
\hline 10.2 & 17.7 & 4.61 & 46.1 & 11.4 & 8.48 & 84.8 & 6.75 \\
\hline 12.7 & 20.0 & 13.6 & 136 & 42.1 & 39.5 & 395 & 16.9 \\
\hline 12.7 & 20.0 & 15.0 & 150 & 43.0 & 40.5 & 405 & 18.4 \\
\hline 15.9 & 22.9 & 63.6 & 636 & 106.3 & 61.5 & 615 & 137 \\
\hline 15.9 & 22.9 & 65.4 & 654 & 97.5 & 58.3 & 583 & 135 \\
\hline
\end{tabular}

As with the lower temperature aging, the higher temperature aging also produced lower yield stresses than the starting gravity-washed simulant for the same insoluble solids content. Figure 3-14 shows a similar downward trend in yield stress for the higher insoluble solids levels. Comparing the yield stress results for the maximum tested aging times (as shown in Figure 3-15) suggests that the rate of reduction is about twice as fast for the boiling test as for the $90{ }^{\circ} \mathrm{C}$ test. Figure 3-15 also demonstrates that neither period of aging reduced the measured yield stress for the ten-liter batch of gravity-washed simulant to the level obtained for the much smaller batch of simulant from the prior year tests. 
WSRC-TR-2005-00543

Revision 0

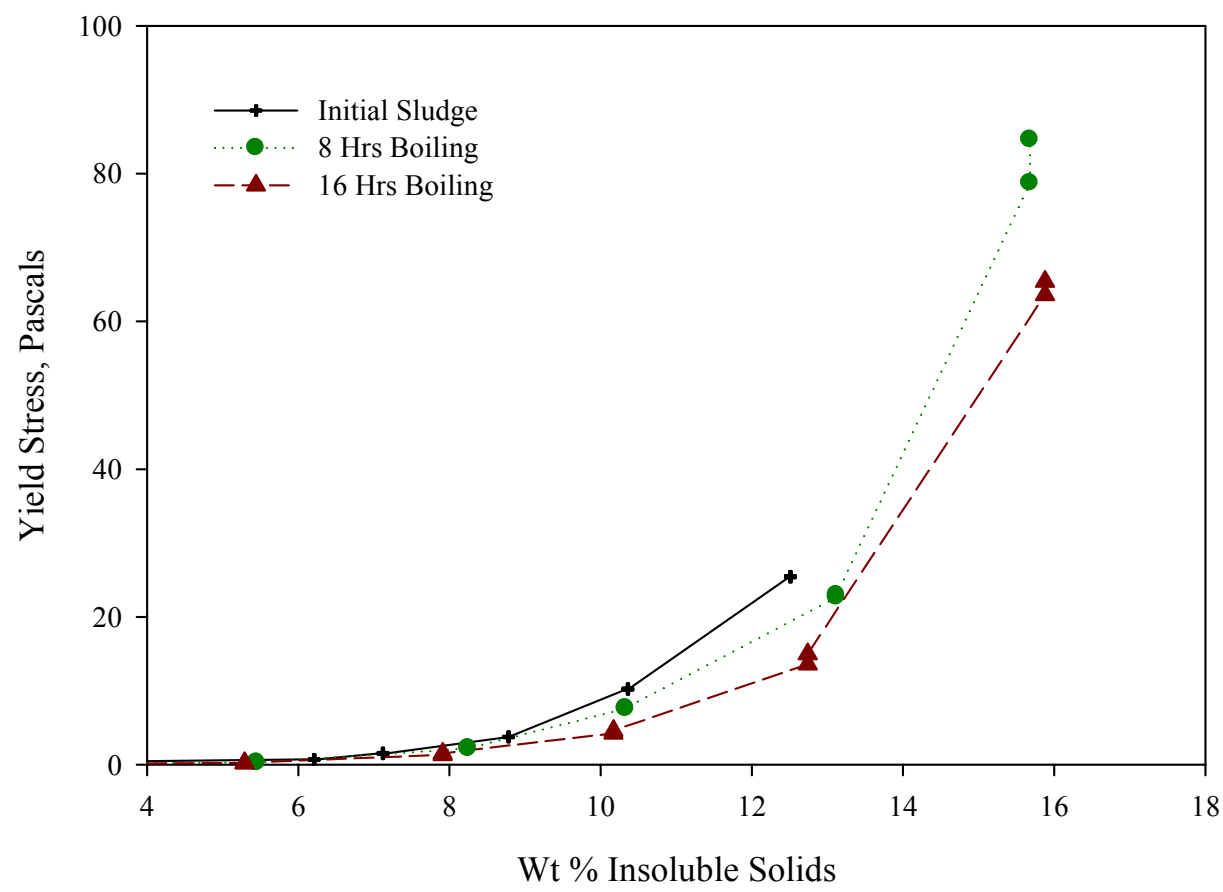

Figure 3-14 Impact of Accelerated Aging by Boiling on the Rheology of Gravity-Washed SB3 Sludge Simulant

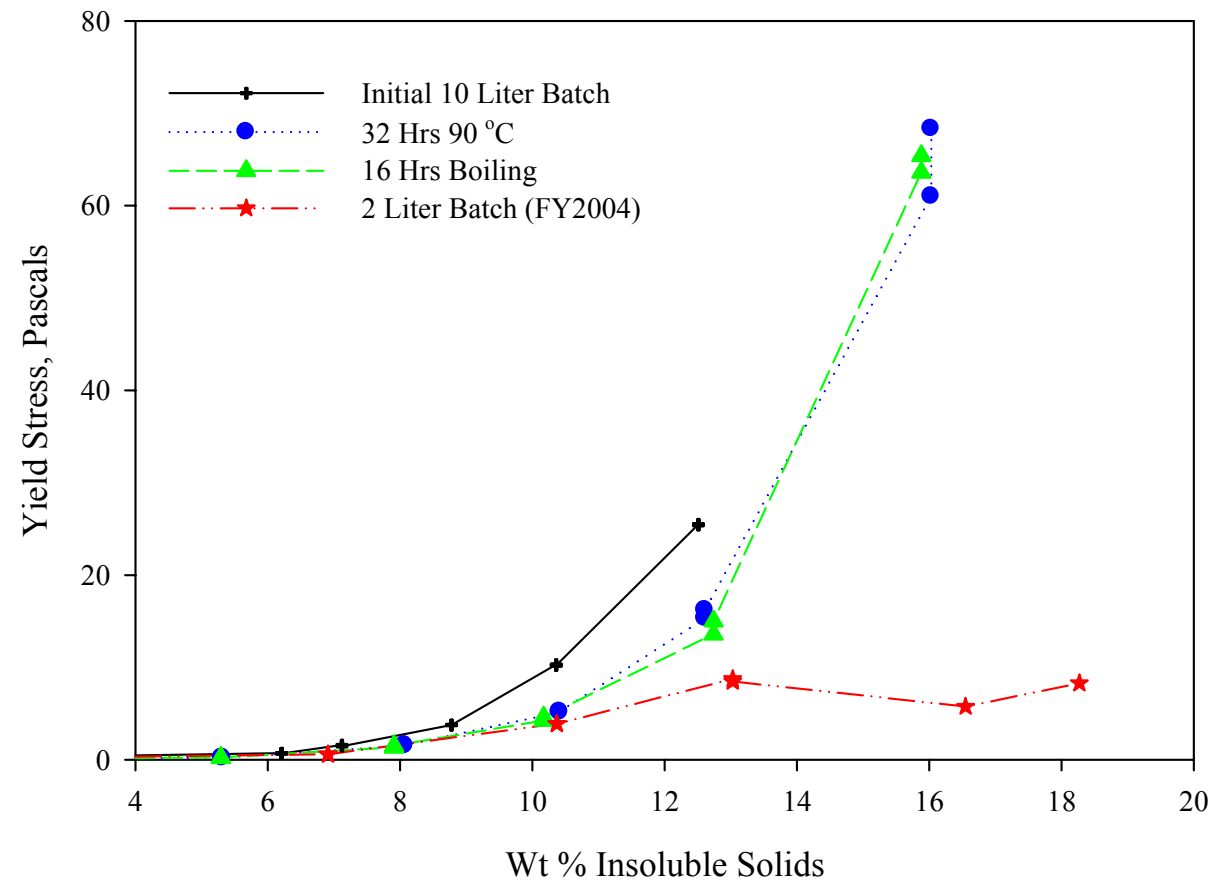

Figure 3-15 Reduction in Yield Stress by Application of Accelerated Aging for Gravity-Washed SB3 Sludge Simulants 
The Bingham consistency was not affected by the accelerated aging at either temperature as shown in Figure 3-16. The consistency for the current batch of gravity-washed SB3 simulant was also higher than that measured for the smaller bath of simulant prepared in 2004.

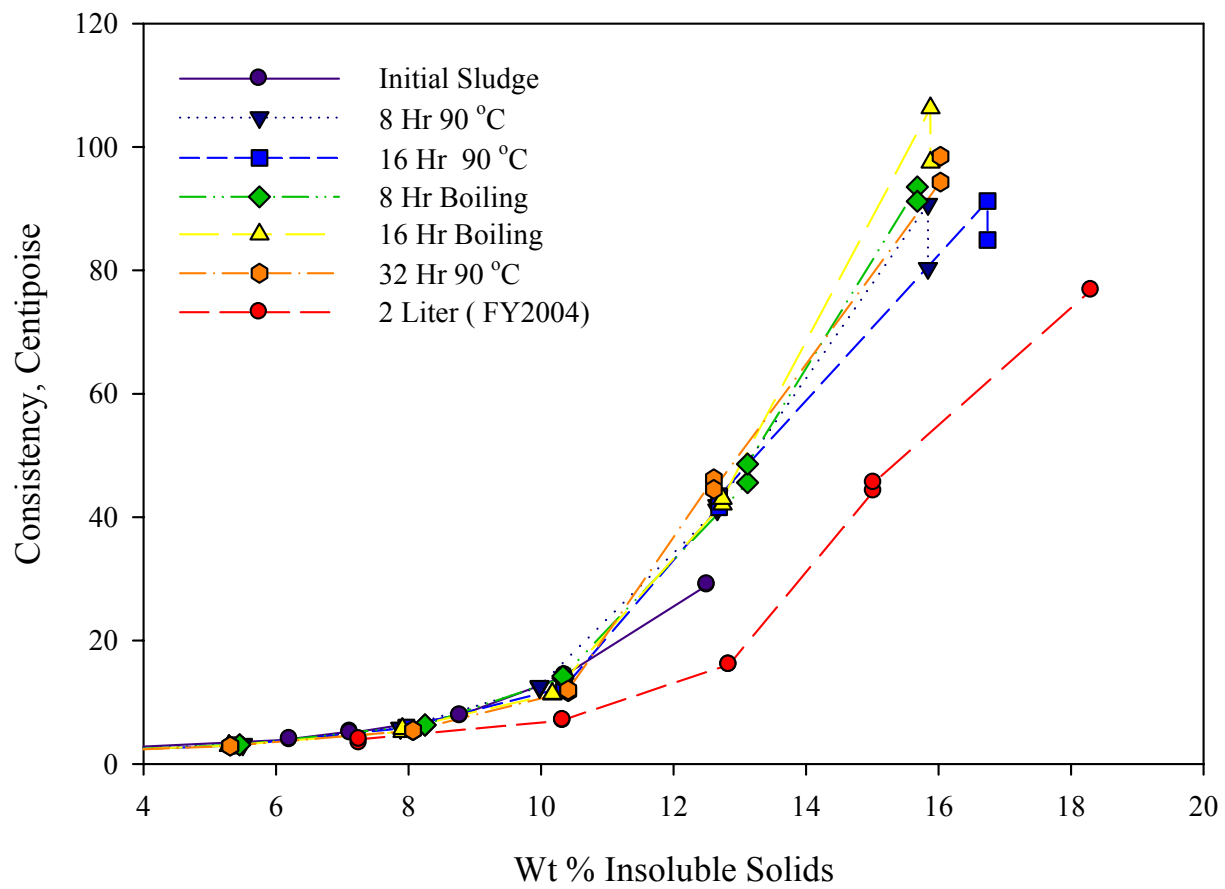

Figure 3-16 Impact of Accelerated Aging on Gravity-Washed SB3 Sludge Simulant Consistency

The particle size analysis results for the aged, gravity-washed SB3 simulant are shown in Table 3-12 and Table 3-13. The average particle size based on volume is reduced by the thermal aging process for both tested conditions suggesting that the largest particles are having their size reduced by either dissolution or recrystallization. The average particle size based on number initially becomes smaller but then shifts to a larger average for both tested conditions. This could indicate an initial dissolution of some of the smaller particles followed by a redeposition (either a fresh precipitate or as a recrystallization) on the existing small particles to shift them to a larger size.

Table 3-12 Particle Size Results for Sludge Simulants after Accelerated Aging at $90{ }^{\circ} \mathrm{C}$

\begin{tabular}{|c|c|c|c|c|c|}
\hline \multirow{2}{*}{ Measurement } & \multirow{2}{*}{ Units } & \multirow{2}{*}{$\begin{array}{c}\text { Initial } \\
\text { Sludge }\end{array}$} & \multicolumn{3}{|c|}{ Accelerated Aged $\left(\mathbf{9 0}{ }^{\circ} \mathbf{C}\right)$ Sludge } \\
\cline { 4 - 6 } & & 8 Hours & $\mathbf{1 6}$ Hours & 32 Hours \\
\hline $\begin{array}{c}\text { Mean - } \\
\text { Volume }\end{array}$ & microns & 23.9 & 20.2 & 17.5 & 18 \\
\hline $\begin{array}{c}\text { Mean - } \\
\text { Number }\end{array}$ & microns & 1.44 & 1.25 & 2.01 & 1.78 \\
\hline Mean - Area & microns & 8.02 & 6.68 & 7.18 & 6.86 \\
\hline CSSA & $\mathrm{m}^{2} / \mathrm{cm}^{3}$ & 0.75 & 0.90 & 0.84 & 0.87 \\
\hline
\end{tabular}


Table 3-13 Particle Size Results for Sludge Simulants after Accelerated Aging at Boiling

\begin{tabular}{|c|c|c|c|c|}
\hline \multirow{2}{*}{ Measurement } & Units & \multirow{2}{*}{$\begin{array}{c}\text { Initial } \\
\text { Sludge }\end{array}$} & \multicolumn{2}{|c|}{$\begin{array}{c}\text { Accelerated Aged } \\
\text { (Boiling) Sludge }\end{array}$} \\
\cline { 4 - 5 } & & 8 Hours & 16 Hours \\
\hline $\begin{array}{c}\text { Mean - } \\
\text { Volume }\end{array}$ & microns & 23.9 & 22.5 & 17.8 \\
\hline $\begin{array}{c}\text { Mean - } \\
\text { Number }\end{array}$ & microns & 1.44 & 1.24 & 1.76 \\
\hline Mean - Area & microns & 8.02 & 6.68 & 6.77 \\
\hline CSSA & $\mathrm{m}^{2} / \mathrm{cm}^{3}$ & 0.75 & 0.90 & 0.89 \\
\hline
\end{tabular}

The particle size distributions for the gravity-washed SB3 simulant aged at boiling for 16 hours shows definite changes in the particles on both volume and number basis. Figure 3-17 shows the distribution on a volume basis which shows that the original bimodal distribution has shifted to a trimodal distribution. The maximum for the largest particle mode remains the same but the width of the mode has narrowed due to the loss of particles above 80 microns. The lowest mode for the aged simulant has a new maximum at about 3 microns.

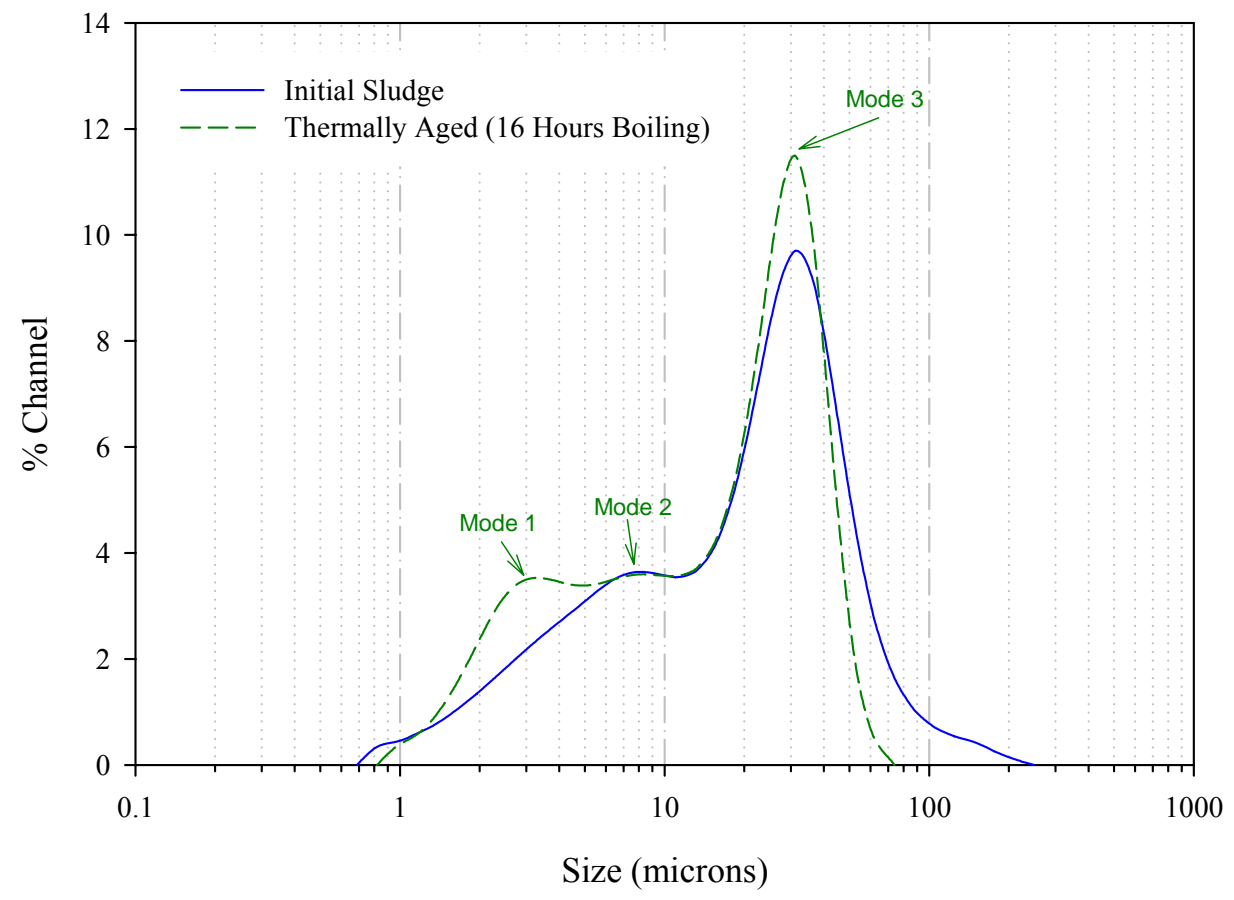

Figure 3-17 Particle Size Distribution (Volume Basis) of the Gravity-Washed SB3 Sludge Simulant after Accelerated Aging (16 Hours Boiling)

The number based distribution shifts from a unimodal to a bimodal distribution as shown in Figure 3-18. The distribution confirms the loss of the smallest particles and a shift for the large number of small particles to a slightly larger particle size. All of the rest of the particle size distributions that were measured for the gravity-washed simulant are shown in APPENDIX A. ADDITIONAL PARTICLE SIZE DISTRIBUTION RESULTS. 


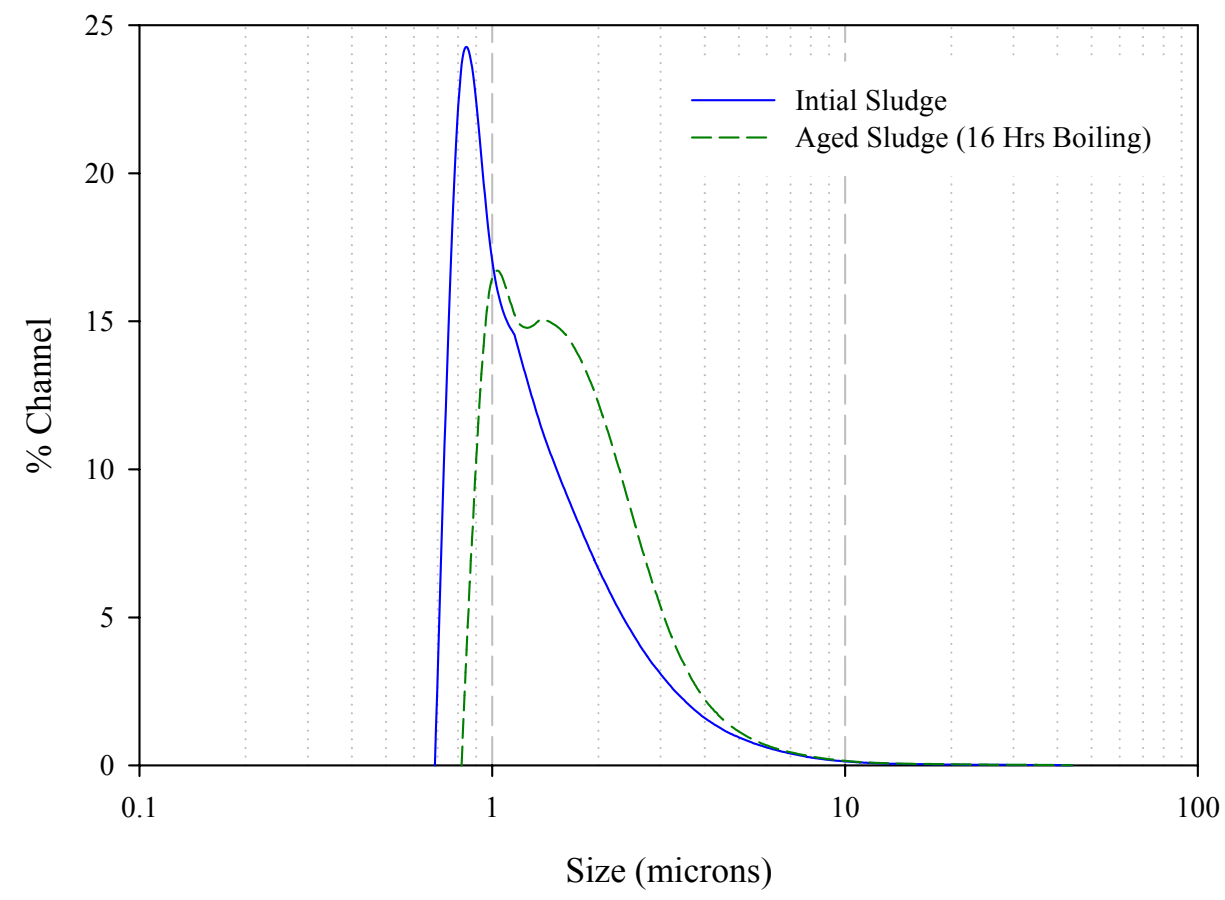

Figure 3-18 Particle Size Distribution (Number Basis) of the Gravity-Washed SB3 Sludge Simulant after Accelerated Aging (16 Hours Boiling)

\subsection{Crossflow-Washed SB3 Sludge Simulant Physical Properties}

Preparing simulated DWPF sludges by gravity washing has several disadvantages even though the process is relatively simple. The two main disadvantages are the large amount of wash water and the low final insoluble solids content produced by the typical Fe-Al sludge. Sludge preparation using continuous washing combined with crossflow filtration to remove the wash water significantly reduces the quantity of wash water. This process, hereafter referred to as crossflow-washed, also provides the ability to adjust the insoluble solids content to a greater extent than does the washing process based on settling. Prior crossflow-washed sludge simulant did not include sludges that had all the metals (including Al) precipitated. Nor were the crossflow-washed sludges tested for the impact of accelerated aging on the sludge simulant properties. Therefore, a large batch ( $\sim 35$ Liters) of crossflow-washed simulant was prepared using the process steps and composition detailed in Section 2.0.

The target batch size for the crossflow-washed SB3 simulant was twenty Liters. Problems with maintaining sufficient flow due to the rheology of the simulant prevented concentrating the simulant to the target insoluble solids concentration. Therefore, approximately 35 Liters of SB3 simulant product was produced at an insoluble solids concentration of $9.30 \mathrm{wt} \%$. The remainder of the physical properties of the simulant are shown in Table 3-14 compared to the target values for the simulant. 
Table 3-14 Crossflow-Washed SB3 Sludge Simulant Product

\begin{tabular}{|c|c|c|}
\cline { 2 - 3 } \multicolumn{1}{c|}{} & Target & Product \\
\hline Volume, Liters & 20 & 35 \\
\hline Density, g/mL & 1.19 & 1.076 \\
\hline Wt \% Total Solids & 20.0 & 17.13 \\
\hline Wt \% Soluble Solids & 7.7 & 7.83 \\
\hline $\begin{array}{c}\text { Wt \% Insoluble } \\
\text { Solids }\end{array}$ & 12.3 & 9.30 \\
\hline
\end{tabular}

The particle size distributions, based on volume and on size, are shown in Figure 3-19. The number distribution shows a large number of particles that are less than one micron, which is consistent with prior simulants that have been exposed to high-levels of shear during or after preparation. The volume distribution curve is bimodal and demonstrates that the upper limit for particles was about 25 microns.

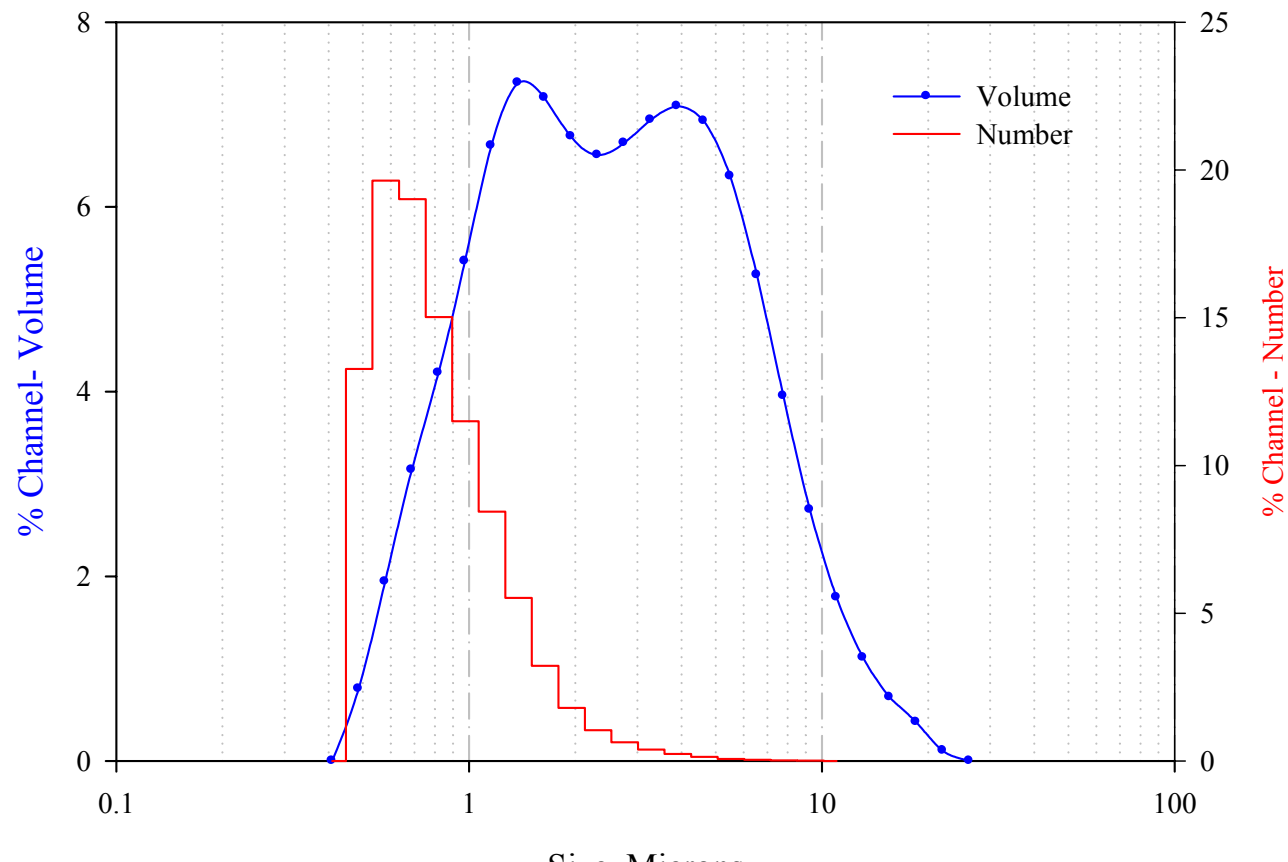

Size, Microns

Figure 3-19 Particle Size Distribution Results for Crossflow-Washed SB3 Sludge Simulant

The average particle sizes based on volume and on number are given in Table 3-15 and are compared to the values determined for the gravity-washed simulant. The continuous application of shear during the washing process has reduced the average particle size based on volume by an order of magnitude. 
Table 3-15 Particle Size Results for Crossflow-Washed SB3 Sludge Simulant

\begin{tabular}{|c|c|c|c|}
\hline Measurement & Units & $\begin{array}{c}\text { Gravity } \\
\text { Washed }\end{array}$ & $\begin{array}{c}\text { Crossflow } \\
\text { Washed }\end{array}$ \\
\hline $\begin{array}{c}\text { Mean - } \\
\text { Volume }\end{array}$ & microns & 23.9 & 3.22 \\
\hline $\begin{array}{c}\text { Mean - } \\
\text { Number }\end{array}$ & microns & 1.44 & 0.81 \\
\hline Mean - Area & microns & 8.02 & 1.73 \\
\hline CSSA & $\mathrm{m}^{2} / \mathrm{cm}^{3}$ & 0.75 & 3.46 \\
\hline
\end{tabular}

The dramatic difference between the crossflow-washed and gravity-washed simulants is shown in Figure 3-20 and Figure 3-21. The shift to producing much smaller particle sizes was also seen in prior testing of DWPF sludge with added aluminum (as the oxide or hydroxide) instead of the precipitated aluminum present in the current tests.

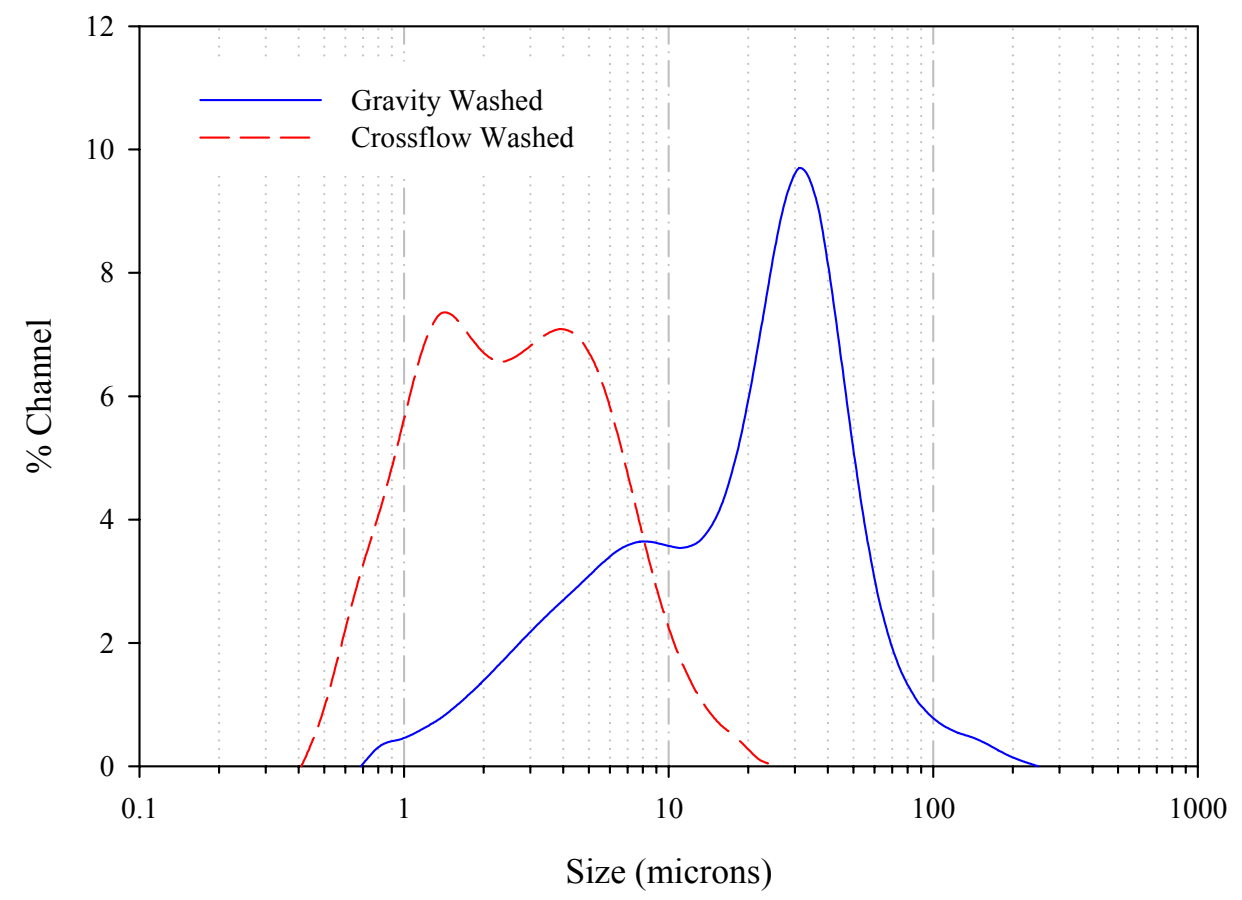

Figure 3-20 Comparison of Particle Size Distribution (Volume Basis) for Crossflow-Washed and Gravity-Washed SB3 Sludge Simulants 


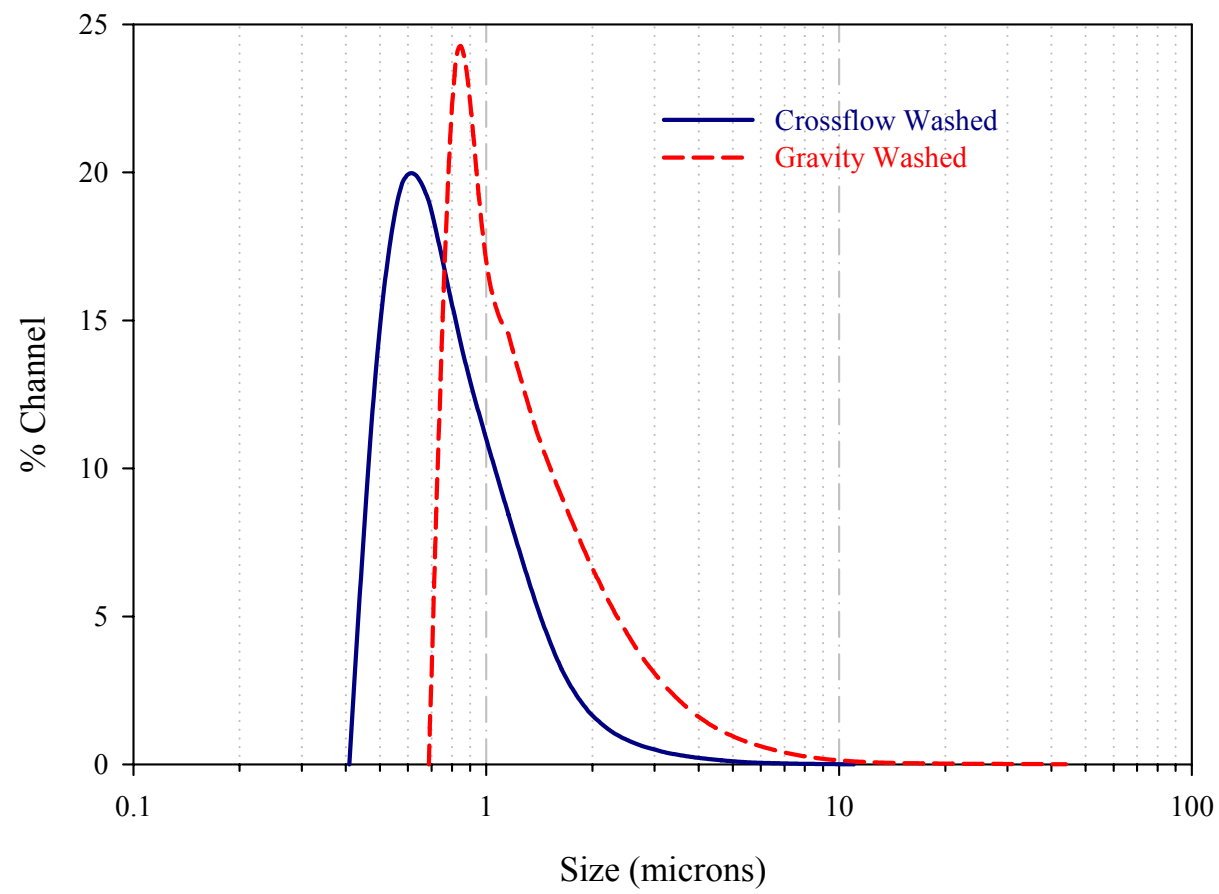

Figure 3-21 Comparison of Particle Size Distribution (Number Basis) for Crossflow-Washed and Gravity-Washed Simulants

Smaller particle sizes have been associated with higher yield stresses in earlier tests. The assumption was made that the use of the crossflow filter for sludge washing would produce a sludge simulant with higher yield stress for equivalent insoluble solids values. The rheology results for the crossflow-washed SB3 simulant are listed in Table 3-16.

Table 3-16 Rheology Results for the Crossflow- Washed Sludge Simulant

\begin{tabular}{|c|c|c|c|c|c|c|c|}
\cline { 3 - 7 } \multicolumn{2}{c|}{} & \multicolumn{3}{c|}{ Up Flow Curve } & \multicolumn{2}{c|}{ Down Flow Curve } \\
\hline $\begin{array}{c}\text { Insoluble } \\
\text { Solids, } \\
\text { wt \% }\end{array}$ & $\begin{array}{c}\text { Total } \\
\text { Solids, } \\
\text { wt \% }\end{array}$ & $\begin{array}{c}\text { Yield } \\
\text { Stress, } \\
\text { Pascal }\end{array}$ & $\begin{array}{c}\text { Yield } \\
\text { Stress, } \\
\text { dynes/cm }\end{array}$ & $\begin{array}{c}\text { Consistency, } \\
\text { cP }\end{array}$ & $\begin{array}{c}\text { Yield } \\
\text { Stress, } \\
\text { Pascal }\end{array}$ & $\begin{array}{c}\text { Yield } \\
\text { Stress, } \\
\text { dynes/cm }\end{array}$ & $\begin{array}{c}\text { Consistency, } \\
\text { cP }\end{array}$ \\
\hline 9.29 & 17.1 & 6.62 & 66.2 & 9.47 & 6.65 & 66.5 & 9.24 \\
\hline 9.29 & 17.1 & 6.69 & 66.9 & 9.53 & 6.76 & 67.6 & 9.19 \\
\hline 9.87 & 17.7 & 10.95 & 109.5 & 10.44 & 11.24 & 112.4 & 10.02 \\
\hline 9.87 & 17.7 & 10.95 & 109.5 & 10.72 & 11.23 & 112.3 & 10.16 \\
\hline 11.2 & 18.8 & 17.77 & 177.7 & 14.8 & 18.73 & 187.3 & 13.3 \\
\hline 11.2 & 18.8 & 17.71 & 177.1 & 14.7 & 18.83 & 188.3 & 13.1 \\
\hline 12.6 & 20.2 & 29.0 & 290 & 23.2 & 31.3 & 313 & 20.2 \\
\hline 12.6 & 20.2 & 28.8 & 288 & 23.4 & 31.1 & 311 & 20.8 \\
\hline 16.2 & 23.5 & 77.8 & 778 & 42.4 & 78.6 & 786 & 42.3 \\
\hline 16.2 & 23.5 & 83.0 & 830 & 27.3 & 75.8 & 758 & 44.3 \\
\hline
\end{tabular}


Figure 3-22 and Figure 3-23 compare the yield stress and consistency results for the crossflow-washed simulant to the gravity-washed simulant and the FY2004 SB3 simulant. The fitted curves in both graphs are based on the modified exponential equation previously defined (equation [6] in section 3.2). The yield stress for the crossflow-washed sludge is not significantly higher than the gravity-washed sludge as expected. Instead, the shape of the fitted curve suggests that the gravity-washed yield stress is increasing faster at the higher insoluble solids levels than the crossflow-washed simulant. The consistency results for all three sludge simulants are similar at the lower insoluble solids levels (less than $11 \mathrm{wt} \%$ ) and diverge above that level with the crossflow-washed simulant having the lowest consistency.

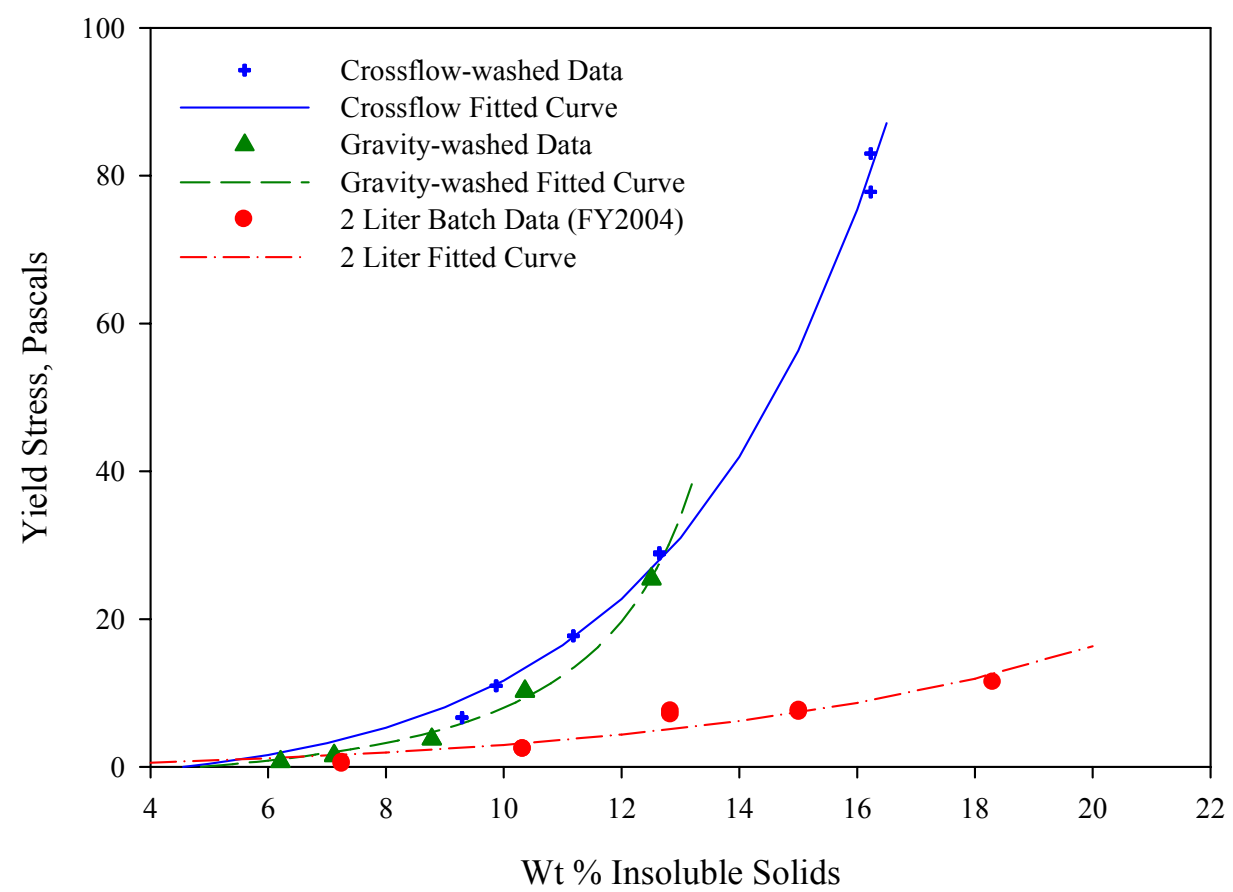

Figure 3-22 Yield Stress Results for the Initial Crossflow-Washed Sludge Simulant 


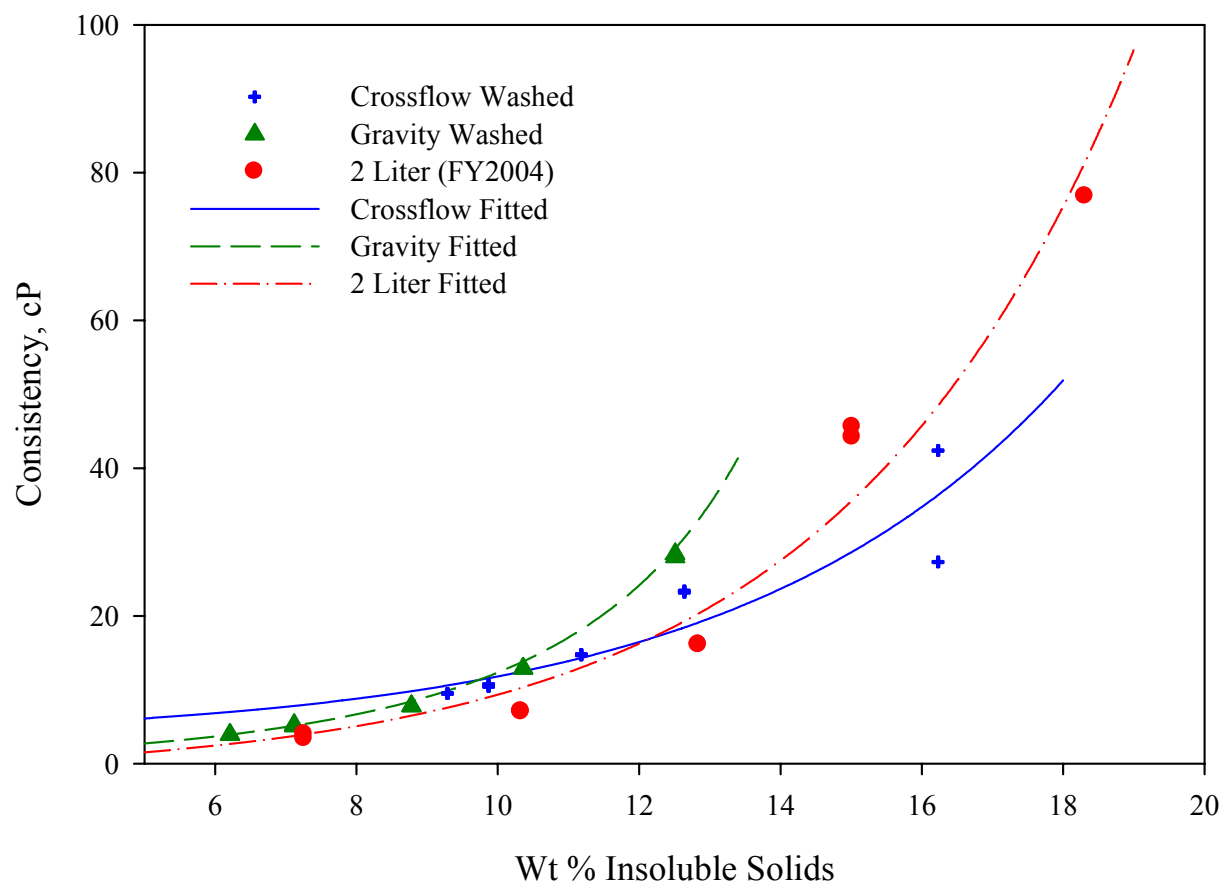

Figure 3-23 Consistency Results for Gravity and Crossflow-Washed SB3 Sludge Simulants

\subsection{Thermally Aged, Crossflow-Washed SB3 Sludge Simulant}

The crossflow-washed SB3 simulant was modified by accelerated aging under three different conditions to test whether the physical properties of the simulant could be modified to make them approach the properties of the previous FY2004 simulant. The tested conditions for the aging were $90{ }^{\circ} \mathrm{C}$ (for 8,16 and 32 hours), and boiling ( 8 and 16 hours). An additional portion of the crossflow-washed sludge was subjected to the accelerated aging ( 27 hours at boiling) before the completion of steps eight and nine in Table 2-5. The additional accelerated aging condition was applied to determine if the aging process would occur better at a lower ionic strength supernate composition. The lower ionic strength could change the degree of aging if the aging process is due to a combination of dissolution followed by reprecipitation/crystallization. The aged crossflow-washed simulants were prepared for analysis by the same series of steps that were used for the gravity-washed simulants.

Samples from the accelerated aging experiments were submitted to AD for analysis by XRD to determine if changes in the sludge phase could be detected as they were in the gravity-washed tests. The initial crossflow-washed simulant and the aged, crossflow-washed simulant (16 hours boiling) XRD results are shown in Figure 3-24 and Figure 3-25 respectively. The initial simulant shows the presence of the silica that was added and of the precipitated aluminum trihydroxide. After aging, the simulant also shows the presence of hematite, $\mathrm{Fe}_{2} \mathrm{O}_{3}$, and possibly sodium aluminosilicate. The presence of the hematite confirms that some of the amorphous iron hydroxides are converting to more crystalline materials. The potential presence of the aluminosilicate as a result of the thermal aging process was expected since the formation of aluminosilicates have also been detected in evaporator bottoms at the Savannah River Site when the evaporator feed includes $\mathrm{Al}$ and $\mathrm{Si}$. The presence of aluminosilicate in DWPF sludge feed has also been suggested as the material that produces the insoluble sodium observed during sludge washing. 


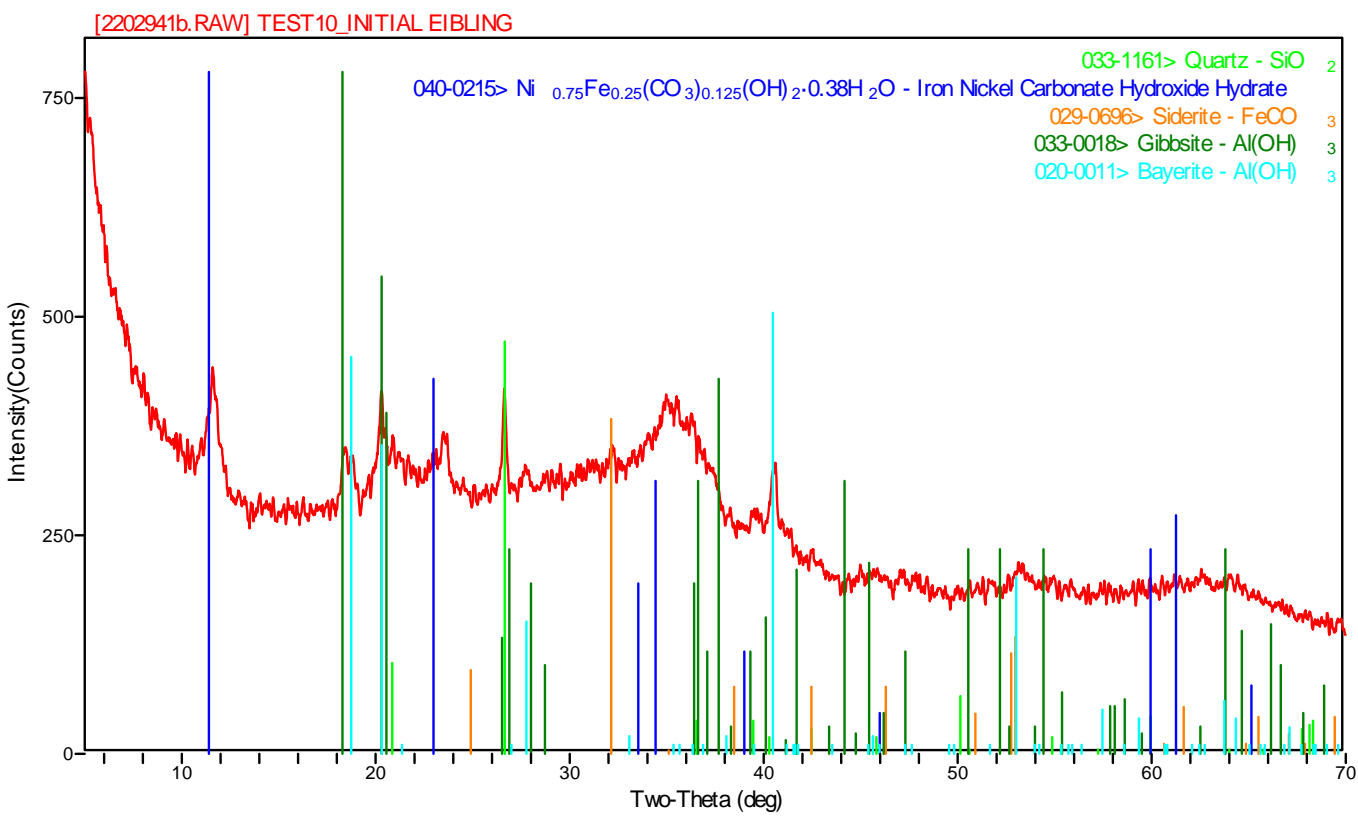

Figure 3-24 X-Ray Diffraction Analysis of Crossflow-Washed, SB3 Sludge Simulant

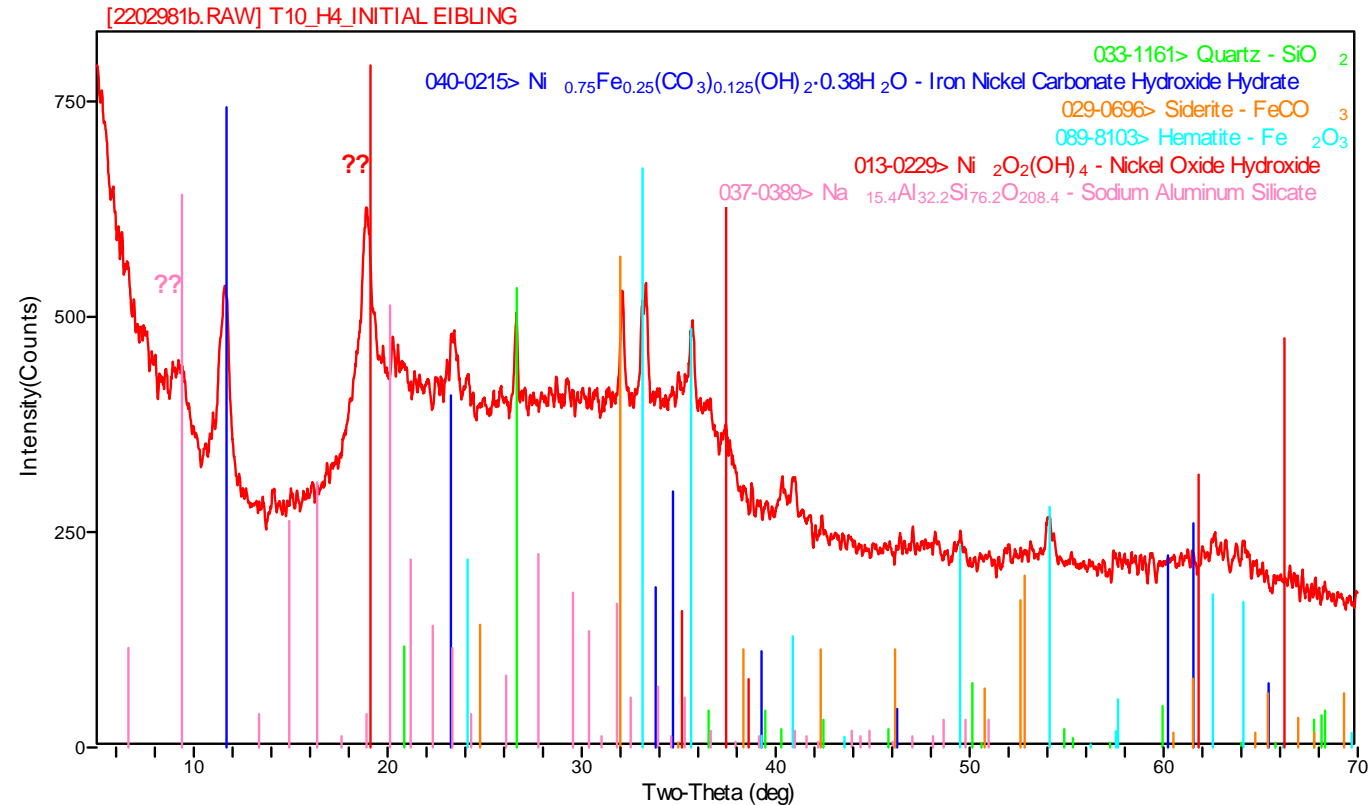

Figure 3-25 X-Ray Diffraction Analysis of Crossflow-Washed, SB3 Sludge Simulant after Accelerated Aging (16 Hours Boiling) 
The aged, crossflow-washed simulants from the $90{ }^{\circ} \mathrm{C}$ and boiling test were analyzed for their particle sizes in the same manner as performed previously for the gravity-washed sludge. The mean particle sizes for both accelerated aging conditions are compared to the initial mean particle size in Table 3-17 and Table 3-18. The shift in mean particle size is small and not very consistent in direction.

Table 3-17 Particle Size Results for Crossflow-Washed Sludge Simulants Aged at $90{ }^{\circ} \mathrm{C}$

\begin{tabular}{|c|c|c|c|c|c|}
\hline \multirow{2}{*}{ Measurement } & \multirow{2}{*}{ Units } & \multirow{2}{*}{ Initial Sludge } & \multicolumn{3}{|c|}{ Accelerated Aged (90 $\left.{ }^{\circ} \mathbf{C}\right)$ Sludge } \\
\cline { 4 - 6 } & mean - & 8 Hours & 16 Hours & 32 Hours \\
\hline $\begin{array}{c}\text { Volume } \\
\text { Mean - } \\
\text { Number }\end{array}$ & microns & 3.22 & 3.24 & 3.35 & 2.99 \\
\hline Mean - Area & microns & 0.81 & 0.85 & 0.81 & 0.86 \\
\hline CSSA & $\mathrm{m}^{2} / \mathrm{cm}^{3}$ & 3.46 & 2.99 & 3.00 & 2.92 \\
\hline
\end{tabular}

Table 3-18 Particle Size Results for Crossflow-Washed Sludge Simulants Aged at Boiling

\begin{tabular}{|c|c|c|c|c|}
\hline \multirow{2}{*}{ Measurement } & Units & \multirow{2}{*}{ Initial Sludge } & \multicolumn{2}{|c|}{$\begin{array}{c}\text { Accelerated Aged } \\
\text { (Boiling) Sludge }\end{array}$} \\
\cline { 4 - 5 } & & 8 Hours & 16 Hours \\
\hline $\begin{array}{c}\text { Mean - } \\
\text { Volume }\end{array}$ & microns & 3.22 & 4.17 & 2.82 \\
\hline $\begin{array}{c}\text { Mean - } \\
\text { Number }\end{array}$ & microns & 0.81 & 0.86 & 0.88 \\
\hline Mean - Area & microns & 1.73 & 1.95 & 1.98 \\
\hline CSSA & $\mathrm{m}^{2} / \mathrm{cm}^{3}$ & 3.46 & 3.08 & 3.04 \\
\hline
\end{tabular}

However, an examination of the particle size distribution on a volume basis or a number basis reveals that changes in the particles are taking place due to the thermal treatment. The volume distribution, shown in Figure 3-26, for the initial crossflow-washed sludge is bimodal with two equal modes centered at 1.0 and 3.4 microns. The volume based distribution for the simulant after 16 hours of boiling is also bimodal but with the main mode at 2.4 microns and a second minor mode at 0.5 microns. The small shift in the overall average particle size is actually a more significant change to a nearly unimodal distribution on a volume basis. The number based particle size distribution, shown in Figure 3-27, also shows a significant shift due to the thermal treatment. The shift is to more particles between one and two microns in size than in the initial simulant. This suggests a growth in some of the smaller particles to a larger size. 


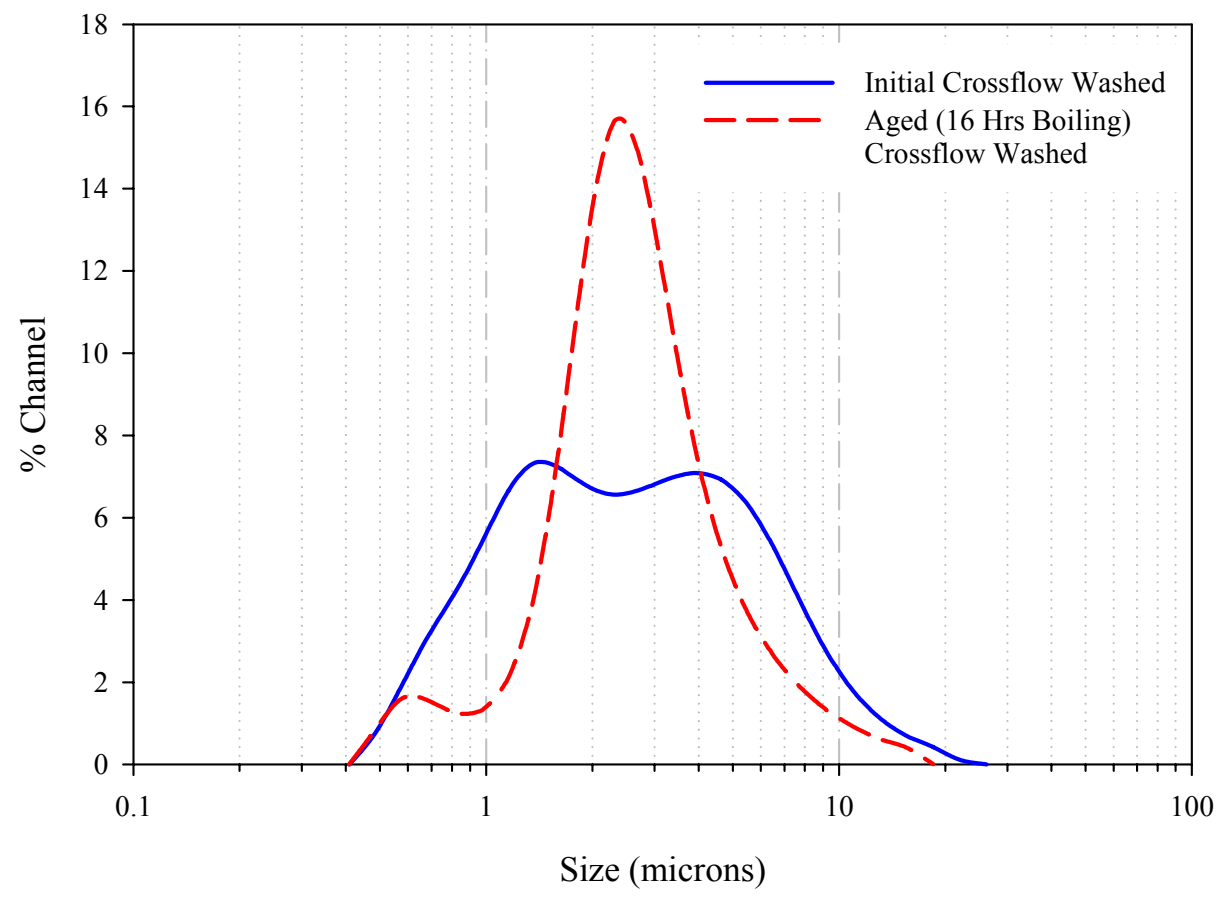

Figure 3-26 Comparison of Particle Size Distribution (Volume Basis) for Aged Crossflow-Washed Simulant

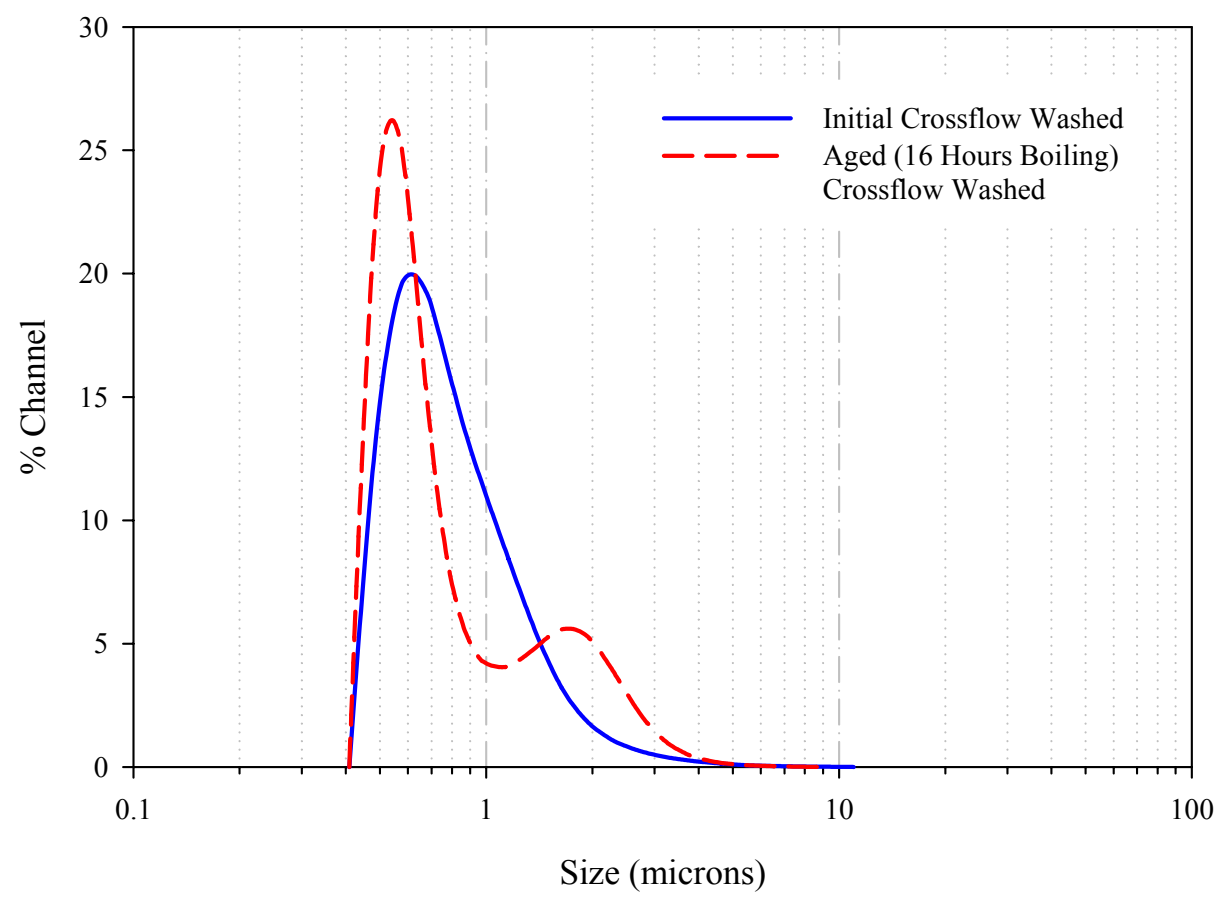

Figure 3-27 Comparison of Particle Size Distribution (Numbered Basis) for Aged Crossflow-Washed Simulant 
The products from each of the accelerated aging experiments at $90^{\circ} \mathrm{C}$ for the crossflow-washed simulant were prepared for rheology analysis as previously described. The Bingham yield stress and consistency results for these products are listed in Table 3-19, Table 3-20, and Table 3-21. As with the gravitywashed simulant, the rheology curves consistently produced up flow curves, which were below the down flow curve.

Table 3-19 Rheology of Crossflow-Washed Sludge Simulant after 8 Hours of Accelerated Aging at $90{ }^{\circ} \mathrm{C}$

\begin{tabular}{|c|c|c|c|c|c|c|c|}
\cline { 3 - 8 } \multicolumn{2}{c|}{} & \multicolumn{3}{c|}{ Up Flow Curve } & \multicolumn{2}{c|}{ Down Flow Curve } \\
\hline $\begin{array}{c}\text { Insoluble } \\
\text { Solids, } \\
\text { wt \% }\end{array}$ & $\begin{array}{c}\text { Total } \\
\text { Solids, } \\
\text { wt \% }\end{array}$ & $\begin{array}{c}\text { Yield } \\
\text { Stress, } \\
\text { Pascal }\end{array}$ & $\begin{array}{c}\text { Yield } \\
\text { Stress, } \\
\text { dynes/cm }\end{array}$ & $\begin{array}{c}\text { Consistency, } \\
\text { cP }\end{array}$ & $\begin{array}{c}\text { Yield } \\
\text { Stress, } \\
\text { Pascal }\end{array}$ & $\begin{array}{c}\text { Yield } \\
\text { Stress, } \\
\text { dynes/cm }\end{array}$ & $\begin{array}{c}\text { Consistency, } \\
\text { cP }\end{array}$ \\
\hline 9.02 & 17.2 & 4.24 & 42.4 & 12.2 & 5.36 & 53.6 & 10.2 \\
\hline 9.02 & 17.2 & 4.3 & 43.0 & 12.3 & 5.68 & 56.8 & 9.9 \\
\hline 10.1 & 18.2 & 11.35 & 113.5 & 17.4 & 15.23 & 152.3 & 11.0 \\
\hline 10.1 & 18.2 & 11.65 & 116.5 & 16.8 & 15.48 & 154.8 & 10.6 \\
\hline 11.3 & 19.3 & 21.6 & 216 & 25.3 & 29.1 & 291 & 13.8 \\
\hline 11.3 & 19.3 & 22.4 & 224 & 25.4 & 30.1 & 301 & 13.6 \\
\hline 12.5 & 20.4 & 38.4 & 384 & 37.6 & 51.1 & 511 & 19.6 \\
\hline 12.5 & 20.4 & 39.1 & 391 & 37.0 & 51.4 & 514 & 19.4 \\
\hline 15.6 & 23.2 & 97.6 & 976 & 82.1 & 118.5 & 1185 & 52.6 \\
\hline 15.6 & 23.29 & 100.1 & 1001 & 68.7 & 113.9 & 1139 & 51.0 \\
\hline
\end{tabular}

Table 3-20 Rheology of Crossflow-Washed Sludge Simulant after 16 Hours of Accelerated Aging at $90{ }^{\circ} \mathrm{C}$

\begin{tabular}{|c|c|c|c|c|c|c|c|}
\cline { 3 - 7 } \multicolumn{2}{c|}{} & \multicolumn{3}{c|}{ Up Flow Curve } & \multicolumn{2}{c|}{ Down Flow Curve } \\
\hline $\begin{array}{c}\text { Insoluble } \\
\text { Solids, } \\
\text { wt \% }\end{array}$ & $\begin{array}{c}\text { Total } \\
\text { Solids, } \\
\text { wt \% }\end{array}$ & $\begin{array}{c}\text { Yield } \\
\text { Stress, } \\
\text { Pascal }\end{array}$ & $\begin{array}{c}\text { Yield } \\
\text { Stress, } \\
\text { dynes/cm }\end{array}$ & $\begin{array}{c}\text { Consistency, } \\
\text { cP }\end{array}$ & $\begin{array}{c}\text { Yield } \\
\text { Stress, } \\
\text { Pascal }\end{array}$ & $\begin{array}{c}\text { Yield } \\
\text { Stress, } \\
\text { dynes/cm }\end{array}$ & $\begin{array}{c}\text { Consistency, } \\
\text { cP }\end{array}$ \\
\hline 9.22 & 17.1 & 3.85 & 38.5 & 11.9 & 4.93 & 49.3 & 10.0 \\
\hline 9.22 & 17.1 & 3.83 & 38.3 & 11.7 & 5.0 & 50 & 9.7 \\
\hline 9.88 & 17.7 & 9.79 & 97.9 & 15.7 & 13.53 & 135.3 & 9.8 \\
\hline 9.88 & 17.7 & 9.96 & 99.6 & 15.8 & 13.63 & 136.3 & 10.0 \\
\hline 10.8 & 18.5 & 17.18 & 171.8 & 23.4 & 23.5 & 235 & 13.1 \\
\hline 10.8 & 18.5 & 17.36 & 173.6 & 23.0 & 23.8 & 238 & 12.6 \\
\hline 12.7 & 20.3 & 31.3 & 313 & 35.2 & 42.6 & 426 & 18.4 \\
\hline 12.7 & 20.3 & 36.9 & 369 & 27.9 & 43.4 & 434 & 18.0 \\
\hline 16.2 & 23.5 & 92.0 & 920 & 41.2 & 97.3 & 973 & 45.2 \\
\hline 16.2 & 23.5 & 89.2 & 892 & 49.5 & 98.0 & 980 & 44.8 \\
\hline
\end{tabular}


Table 3-21 Rheology of Crossflow-Washed Sludge Simulant after 32 Hours of Accelerated Aging at $90{ }^{\circ} \mathrm{C}$

\begin{tabular}{|c|c|c|c|c|c|c|c|}
\cline { 3 - 7 } \multicolumn{2}{c|}{} & \multicolumn{3}{c|}{ Up Flow Curve } & \multicolumn{2}{c|}{ Down Flow Curve } \\
\hline $\begin{array}{c}\text { Insoluble } \\
\text { Solids, } \\
\text { wt \% }\end{array}$ & $\begin{array}{c}\text { Total } \\
\text { Solids, } \\
\text { wt \% }\end{array}$ & $\begin{array}{c}\text { Yield } \\
\text { Stress, } \\
\text { Pascal }\end{array}$ & $\begin{array}{c}\text { Yield } \\
\text { Stress, } \\
\text { dynes/cm }\end{array}$ & $\begin{array}{c}\text { Consistency, } \\
\text { cP }\end{array}$ & $\begin{array}{c}\text { Yield } \\
\text { Stress, } \\
\text { Pascal }\end{array}$ & $\begin{array}{c}\text { Yield } \\
\text { Stress, } \\
\text { dynes/cm }\end{array}$ & $\begin{array}{c}\text { Consistency, } \\
\text { cP }\end{array}$ \\
\hline 9.11 & 17.3 & 3.72 & 37.2 & 11.9 & 4.5 & 45 & 10.4 \\
\hline 9.11 & 17.3 & 3.67 & 36.7 & 12.0 & 4.57 & 45.7 & 10.2 \\
\hline 9.57 & 17.7 & 10.5 & 105 & 15.6 & 13.5 & 135 & 10.6 \\
\hline 9.57 & 17.7 & 10.5 & 105 & 15.6 & 13.5 & 135 & 10.7 \\
\hline 11.1 & 19.1 & 18.0 & 180 & 22.6 & 23.2 & 232 & 14.2 \\
\hline 11.1 & 19.1 & 18.1 & 181 & 22.8 & 23.2 & 232 & 14.4 \\
\hline 12.4 & 20.3 & 31.9 & 319 & 31.2 & 39.2 & 392 & 19.9 \\
\hline 12.4 & 20.3 & 32.5 & 325 & 30.4 & 39 & 390 & 20.5 \\
\hline 15.5 & 23.1 & 82.7 & 827 & 53.9 & 91.4 & 914 & 43.5 \\
\hline 15.5 & 23.1 & 88.6 & 886 & 48.8 & 88.6 & 886 & 41.3 \\
\hline
\end{tabular}

The yield stress and consistency results as a function of insoluble solids are shown in Figure 3-28 and Figure 3-29 for the $90{ }^{\circ} \mathrm{C}$ aged simulant. Unlike the results for the gravity-washed simulant, the $90{ }^{\circ} \mathrm{C}$ aging process did not lower the yield stress for the crossflow-washed simulant. Instead, the yield stress for the higher solids loading samples was greater than the initial sludge yield stress for equivalent insoluble solids content. The consistency was generally higher for the $90{ }^{\circ} \mathrm{C}$ samples than the initial sludge simulant. 


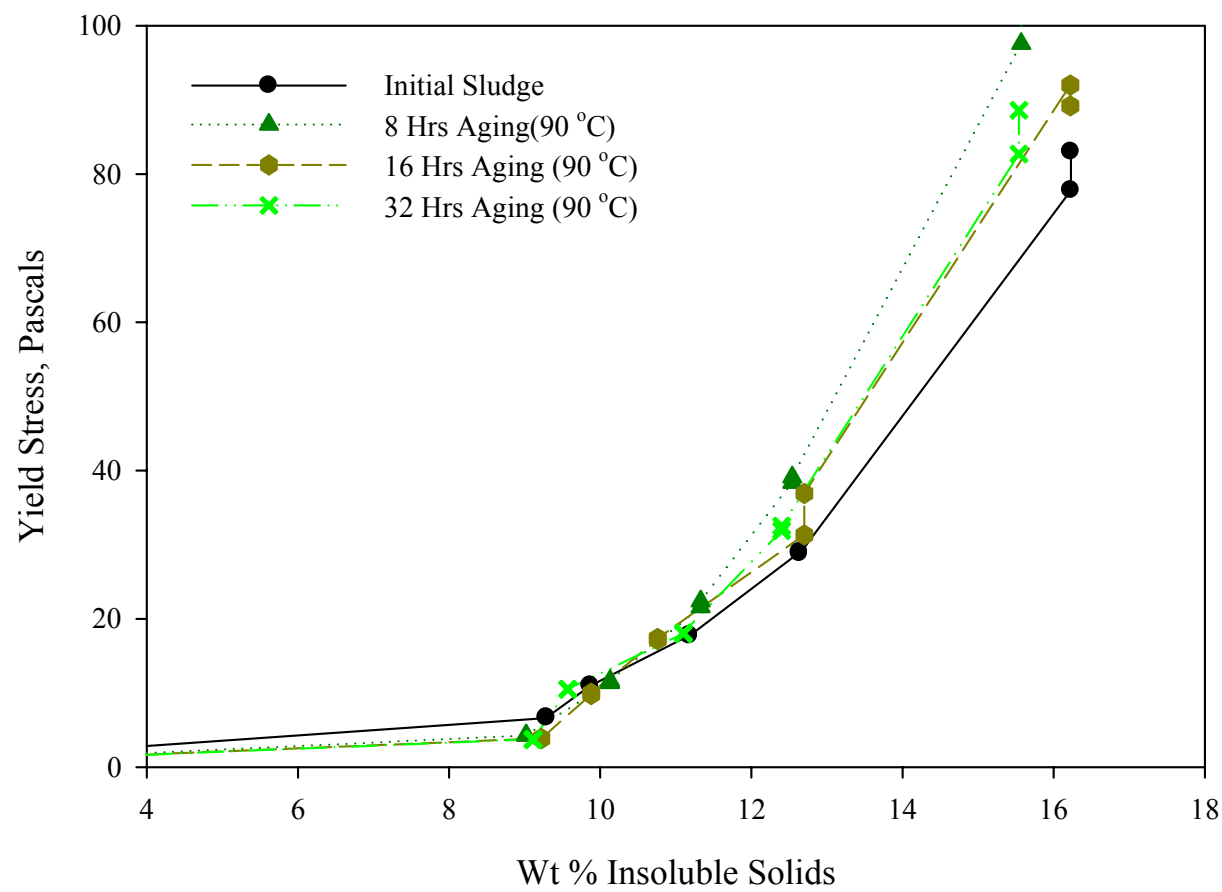

Figure 3-28 Yield Stress of Crossflow-Washed SB3 Simulant after Accelerated Aging at $90{ }^{\circ} \mathrm{C}$

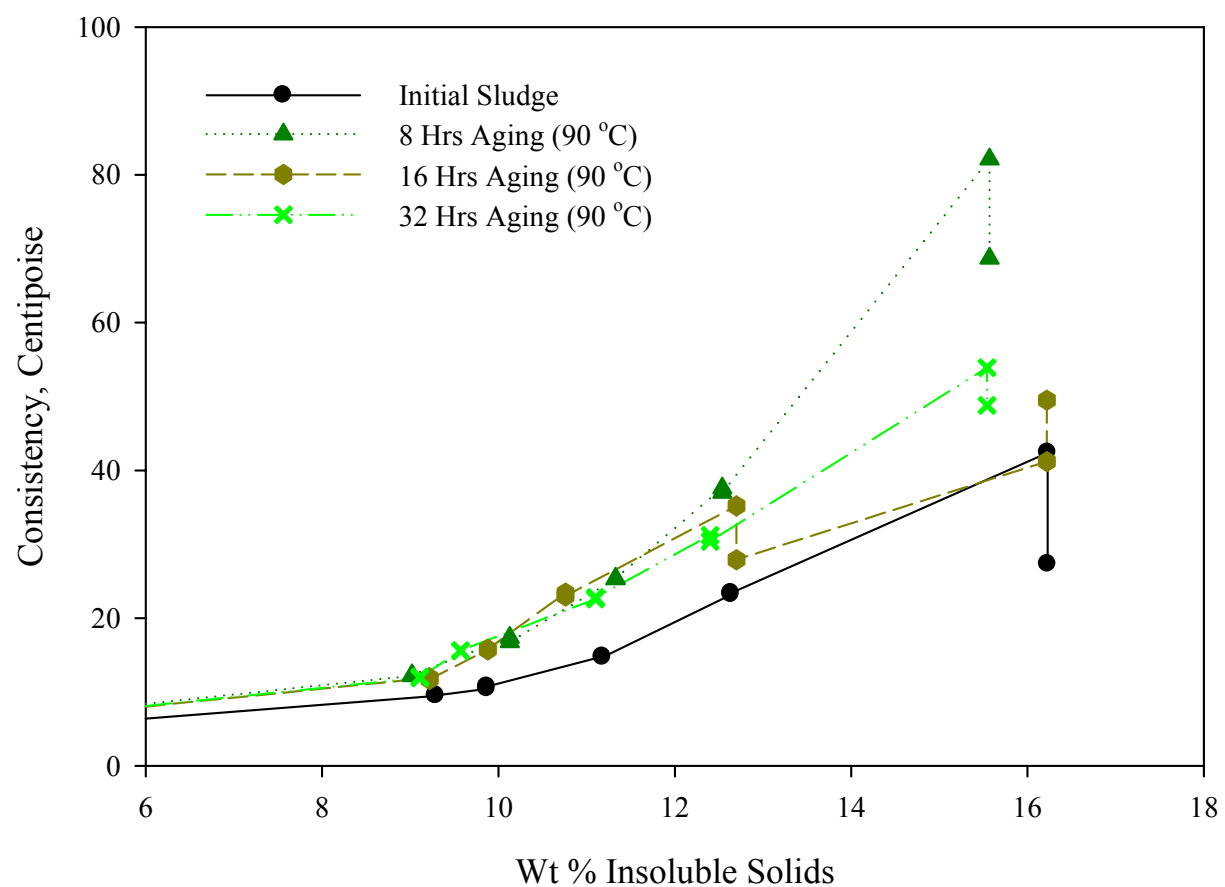

Figure 3-29 Consistency of Crossflow-Washed SB3 Simulant after Accelerated Aging at $90^{\circ} \mathrm{C}$

Similar results were obtained for the crossflow-washed simulant aged under boiling conditions. The rheology results are listed in Table 3-22 and Table 3-23. Table 3-24 gives the rheology results for an 
WSRC-TR-2005-00543

Revision 0

additional portion of the crossflow-washed simulant, which was given an additional wash and aged at boiling for 27 hours before addition of the remaining supernate salts.

Table 3-22 Rheology of Crossflow-Washed Sludge Simulant after 8 Hours of Accelerated Aging at Boiling

\begin{tabular}{|c|c|c|c|c|c|c|c|}
\cline { 3 - 7 } \multicolumn{2}{c|}{} & \multicolumn{3}{c|}{ Up Flow Curve } & \multicolumn{3}{c|}{ Down Flow Curve } \\
\hline $\begin{array}{c}\text { Insoluble } \\
\text { Solids, } \\
\text { wt \% }\end{array}$ & $\begin{array}{c}\text { Total } \\
\text { Solids, } \\
\text { wt \% }\end{array}$ & $\begin{array}{c}\text { Yield } \\
\text { Stress, } \\
\text { Pascal }\end{array}$ & $\begin{array}{c}\text { Yield } \\
\text { Stress, } \\
\text { dynes/cm }\end{array}$ & $\begin{array}{c}\text { Consistency, } \\
\text { cP }\end{array}$ & $\begin{array}{c}\text { Yield } \\
\text { Stress, } \\
\text { Pascal }\end{array}$ & $\begin{array}{c}\text { Yield } \\
\text { Stress, } \\
\text { dynes/cm }\end{array}$ & $\begin{array}{c}\text { Consistency, } \\
\text { cP }\end{array}$ \\
\hline 9.37 & 17.4 & 4.41 & 44.1 & 12.7 & 5.62 & 56.2 & 10.5 \\
\hline 9.37 & 17.4 & 4.36 & 43.6 & 12.7 & 5.69 & 56.9 & 10.3 \\
\hline 9.56 & 17.5 & 8.57 & 85.7 & 15.6 & 11.7 & 117 & 10.6 \\
\hline 9.56 & 17.5 & 8.48 & 84.8 & 15.6 & 11.7 & 117 & 10.6 \\
\hline 10.9 & 18.8 & 15.5 & 155 & 24.5 & 21.8 & 218 & 14.2 \\
\hline 10.9 & 18.8 & 15.5 & 155 & 23.7 & 21.5 & 215 & 14.2 \\
\hline 11.7 & 19.5 & 24.7 & 247 & 30.8 & 33.6 & 336 & 17.1 \\
\hline 11.7 & 19.5 & 25.0 & 250 & 31.2 & 34.4 & 344 & 16.7 \\
\hline 14.9 & 22.4 & 80.0 & 800 & 65.8 & 97.4 & 974 & 44.7 \\
\hline 14.9 & 22.4 & 82.7 & 827 & 64.0 & 97.2 & 972 & 47.3 \\
\hline
\end{tabular}

Table 3-23 Rheology of Crossflow-Washed Sludge Simulant after 16 Hours of Accelerated Aging at Boiling

\begin{tabular}{|c|c|c|c|c|c|c|c|}
\cline { 3 - 7 } \multicolumn{2}{c|}{} & \multicolumn{3}{c|}{ Up Flow Curve } & \multicolumn{2}{c|}{ Down Flow Curve } \\
\hline $\begin{array}{c}\text { Insoluble } \\
\text { Solids, } \\
\text { wt \% }\end{array}$ & $\begin{array}{c}\text { Total } \\
\text { Solids, } \\
\text { wt \% }\end{array}$ & $\begin{array}{c}\text { Yield } \\
\text { Stress, } \\
\text { Pascal }\end{array}$ & $\begin{array}{c}\text { Yield } \\
\text { Stress, } \\
\text { dynes/cm }\end{array}$ & $\begin{array}{c}\text { Consistency, } \\
\text { cP }\end{array}$ & $\begin{array}{c}\text { Yield } \\
\text { Stress, } \\
\text { Pascal }\end{array}$ & $\begin{array}{c}\text { Yield } \\
\text { Stress, } \\
\text { dynes/cm }\end{array}$ & $\begin{array}{c}\text { Consistency, } \\
\text { cP }\end{array}$ \\
\hline 8.93 & 17.2 & 2.82 & 28.2 & 10.3 & 3.33 & 33.3 & 9.28 \\
\hline 8.93 & 17.2 & 2.83 & 28.3 & 10.2 & 3.36 & 33.6 & 9.24 \\
\hline 9.90 & 18.0 & 8.56 & 85.6 & 16.2 & 11.4 & 114 & 11.3 \\
\hline 9.90 & 18.0 & 8.8 & 88 & 15.9 & 11.8 & 118 & 10.9 \\
\hline 11.3 & 19.3 & 16.8 & 168 & 24.6 & 22.8 & 228 & 14.5 \\
\hline 11.3 & 19.3 & 16.9 & 169 & 24.3 & 22.8 & 228 & 14.5 \\
\hline 12.6 & 20.5 & 34.8 & 348 & 21.3 & 29.8 & 298 & 23.8 \\
\hline 12.6 & 20.5 & 32.3 & 323 & 32.2 & 40.4 & 404 & 19.1 \\
\hline 15.2 & 22.9 & 96.7 & 967 & 25.8 & 91.3 & 913 & 45.4 \\
\hline 15.2 & 22.9 & 93.2 & 932 & 28.2 & 88.0 & 880 & 47.7 \\
\hline
\end{tabular}


WSRC-TR-2005-00543

Revision 0

Table 3-24 Rheology of Extended-Wash Sludge Simulant after 27 Hours of Accelerated Aging at Boiling

\begin{tabular}{|c|c|c|c|c|c|c|c|}
\cline { 3 - 7 } \multicolumn{2}{c|}{} & \multicolumn{3}{c|}{ Up Flow Curve } & \multicolumn{2}{c|}{ Down Flow Curve } \\
\hline $\begin{array}{c}\text { Insoluble } \\
\text { Solids, } \\
\text { wt \% }\end{array}$ & $\begin{array}{c}\text { Total } \\
\text { Solids, } \\
\text { wt \% }\end{array}$ & $\begin{array}{c}\text { Yield } \\
\text { Stress, } \\
\text { Pascal }\end{array}$ & $\begin{array}{c}\text { Yield } \\
\text { Stress, } \\
\text { dynes/cm }\end{array}$ & $\begin{array}{c}\text { Consistency, } \\
\text { cP }\end{array}$ & $\begin{array}{c}\text { Yield } \\
\text { Stress, } \\
\text { Pascal }\end{array}$ & $\begin{array}{c}\text { Yield } \\
\text { Stress, } \\
\text { dynes/cm }\end{array}$ & $\begin{array}{c}\text { Consistency, } \\
\text { cP }\end{array}$ \\
\hline 5.37 & 13.2 & 0.47 & 4.7 & 3.32 & 0.47 & 4.7 & 3.32 \\
\hline 5.37 & 13.2 & 0.47 & 4.7 & 3.32 & 0.47 & 4.7 & 3.32 \\
\hline 9.97 & 17.4 & 11.9 & 119 & 13.9 & 14.4 & 144 & 10.1 \\
\hline 9.97 & 17.4 & 11.7 & 117 & 13.9 & 14.3 & 143 & 10.0 \\
\hline 11.8 & 19.1 & 20.5 & 205 & 20.6 & 26.0 & 260 & 12.7 \\
\hline 11.8 & 19.1 & 19.8 & 198 & 22.0 & 26.0 & 260 & 12.9 \\
\hline 12.6 & 19.8 & 31.3 & 313 & 26.7 & 37.2 & 372 & 20.0 \\
\hline 12.6 & 19.8 & 31.4 & 314 & 28.2 & 38.1 & 381 & 20.7 \\
\hline 15.5 & 22.5 & 84.9 & 849 & 44.6 & 96.1 & 961 & 28.9 \\
\hline 15.5 & 22.5 & 85.3 & 853 & 45.4 & 95.0 & 950 & 32.9 \\
\hline
\end{tabular}

The yield stress results as a function of insoluble solids are shown in Figure 3-30 and the consistency results in Figure 3-31. At low insoluble solids content the yield stress for the aged simulant is the same as for the starting simulant. At high insoluble solids levels, the yield stress for the aged simulant is greater than the initial starting simulant. Additionally, there is no apparent time dependence for the difference. As in all of the previous tests, the consistency results do not show any pattern to their values. 
WSRC-TR-2005-00543

Revision 0

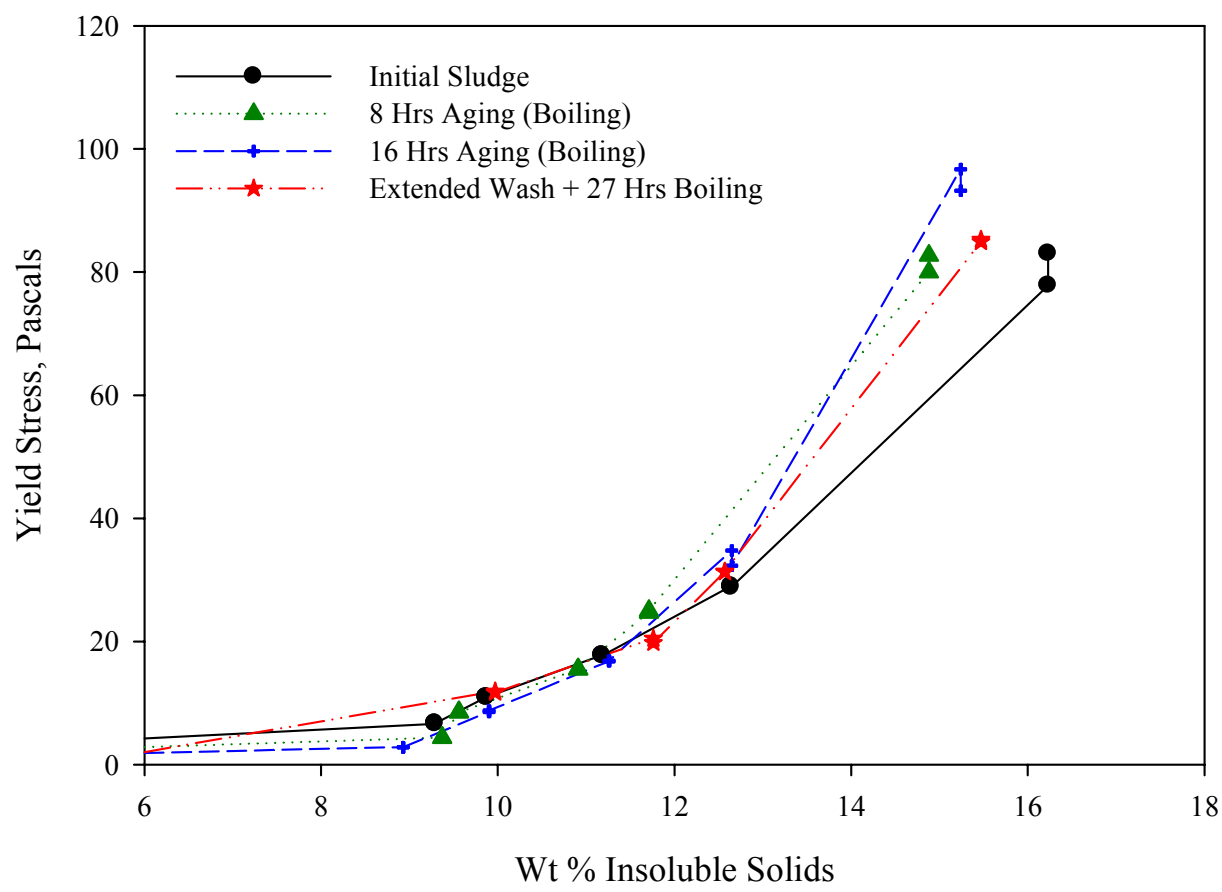

Figure 3-30 Yield Stress of Crossflow-Washed SB3 Sludge Simulant after Accelerated Aging by Boiling

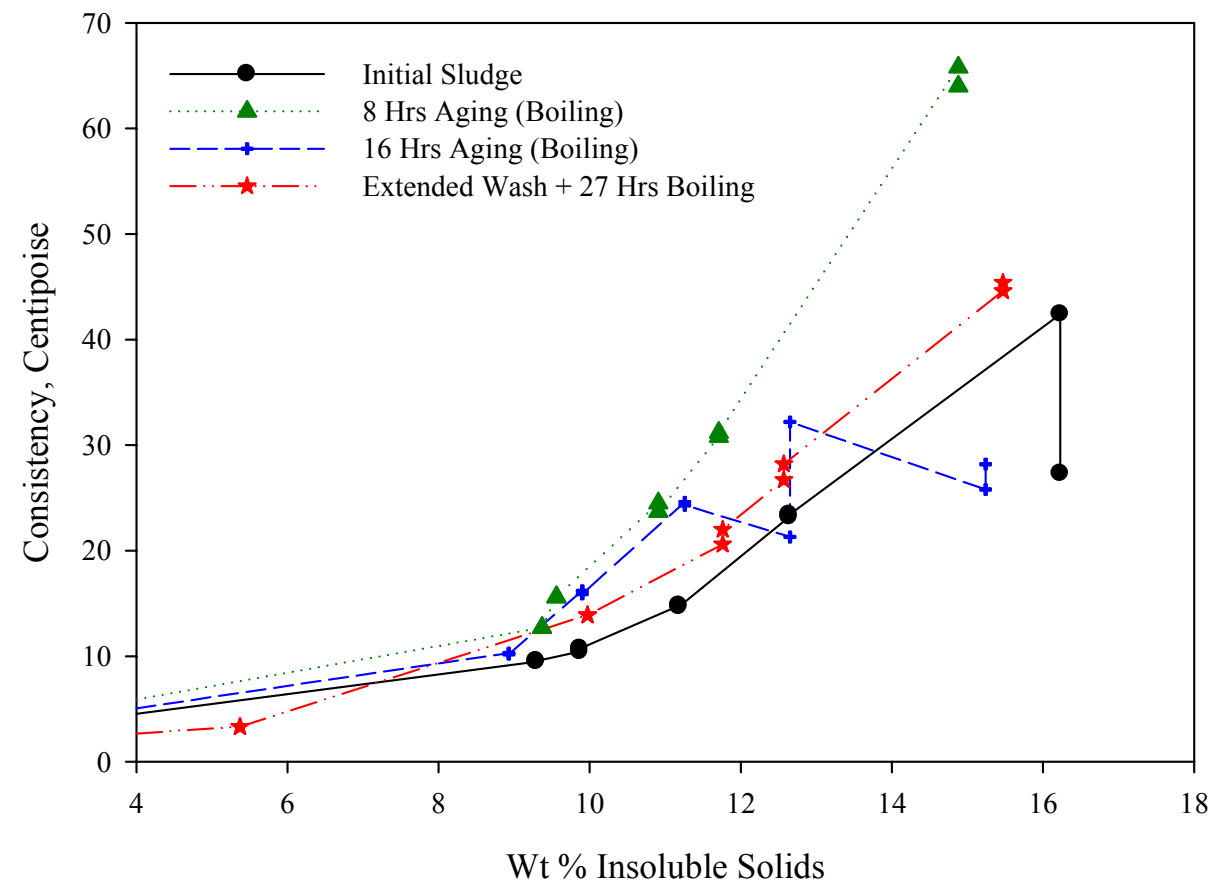

Figure 3-31 Consistency of Crossflow-Washed SB3 Sludge Simulant after Accelerated Aging by Boiling 
WSRC-TR-2005-00543

Revision 0

This page intentionally left blank. 


\subsection{CONCLUSIONS}

The testing performed as part of the effort to enhance the understanding about the production of sludge simulants has demonstrated the complexity of producing a simulant with specific desired physical properties. As a result of these tests, the following conclusions were made:

- The application of a rapid dose of radiation on a sludge simulant did not change the particle size distribution of the simulant.

- The application of a rapid dose of radiation on a sludge simulant did not change the detectable crystalline phases based upon x-ray diffraction.

- Irradiation over a limited time did not modify the rheology of the SB3 sludge simulant.

- SB3 simulant prepared in larger batches as a part of this study does not match the rheology of SB3 simulant prepared in smaller batches. This suggests that scale-dependent parameters such as shear may be important in determining the product rheology.

- Accelerated aging through thermal treatment increases the sludge crystallinity based upon x-ray diffraction.

- Particle size does not necessarily relate to the rheological properties of the slurry.

- Accelerated aging reduced the yield stress of the gravity-washed SB3 simulant as a function of both time and temperature. However, the degree of reduction remains small. Extended times (greater than one week) might be necessary to achieve greater reductions.

- Accelerated aging did not reduce and instead appeared to increase the yield stress of the crossflow-washed simulant. This suggests that additional factors such as particle size and particle morphology might be more important than a limited heat treatment. 
WSRC-TR-2005-00543

Revision 0

This page intentionally left blank. 


\subsection{RECOMMENDATIONS/PATH FORWARD}

The results of the current sludge preparation study indicate that there are additional unknown parameters that modify the physical properties of a DWPF sludge simulant. Additional studies are recommended to improve the understanding of the important properties (chemical and physical) of DWPF sludges.

- Development of a new simulant should include tests to determine if simulant properties are reproducible and how the scale of the simulant preparation affects the simulant properties.

- Develop an understanding of the specific solids generating steps with respect to parameters such as shear, temperature, and additional species present

- Examine the impact of compositional changes on simulant physical properties

- Explore the potential for utilizing controlled shear precipitation to produce DWPF precipitated sludge simulants. Methods such as in-line precipitation using in-line mixers or small vessel, continuously -stirred reactors could be tested.

- Determine why the application of heat is more effective on some sludge compositions than on other compositions. 
WSRC-TR-2005-00543

Revision 0

This page intentionally left blank. 


\subsection{REFERENCES}

1. Eibling, R. E., Schumacher, R. F. and E. K. Hansen. Development of Simulants to Support Mixing Tests for High Level Waste and Low Activity Waste. WSRC-TR-2003-00220, Rev. 0, SRT-RPP-2003-00098, Rev 0. Savannah River Site, Aiken SC 29808 (December 2003).

2. Eibling, R. E. Impact of Simulant Production Methods on the Physical Properties of DWPF Sludge Batch 3 Simulant. WSRC-TR-2004-00578. Savannah River Site, Aiken SC 29808 (January 2005).

3. Pareizs, J. M., Fellinger, T. L. and D. R. Click. Characterization of the March 2004 Yank 40 (Sludge Batch 3) Dip Samples. WSRC-TR-2004-00208, Savannah River Site, Aiken SC 29808 (May 2004)

4. Koopman, D. C. DWPF Hydrogen Generation Study: Phase II - Form of Noble Metal SRAT Testing. WSRC-TR-2005-00420. Savannah River Site, Aiken SC 29808 (December 2005). 
WSRC-TR-2005-00543

Revision 0

This page intentionally left blank. 


\subsection{ACKNOWLEDGEMENTS}

This study could not be performed without the assistance and support of the following people: E. K. Hansen, M. J. Barnes, N. E. Bibler, M. F. Williams, V. J. Williams, D. P. Healey, J. W. Duvall, R. J. Workman, D. M. Marsh, and D. C. Beam. 
WSRC-TR-2005-00543

Revision 0

This page intentionally left blank. 
WSRC-TR-2005-00543

Revision 0

APPENDIX A. Additional Particle Size Distribution Results 


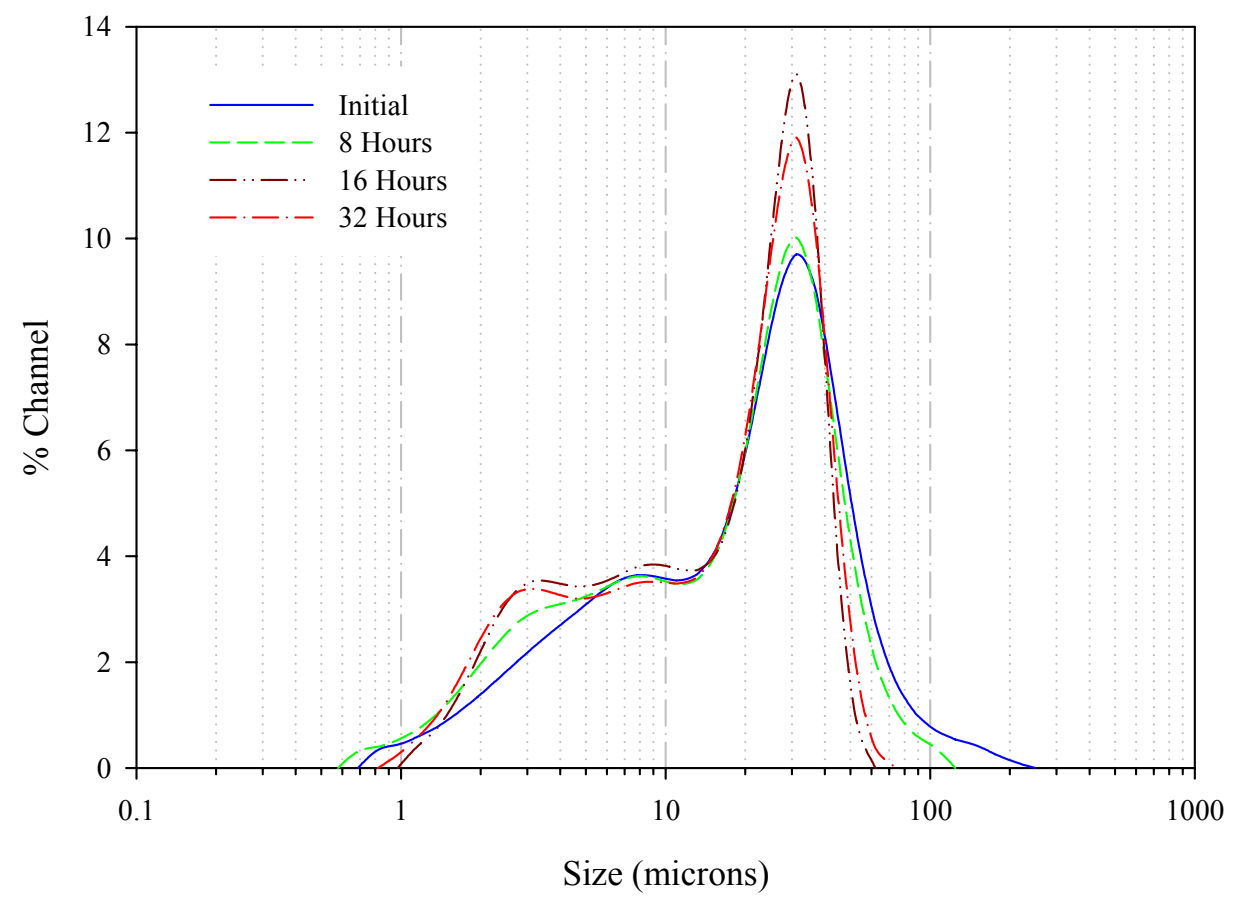

Figure A- 1 Impact of Thermal Aging $\left(90^{\circ} \mathrm{C}\right)$ on Particle Size Distribution Volume Basis on Gravity-Washed SB3 Sludge Simulant

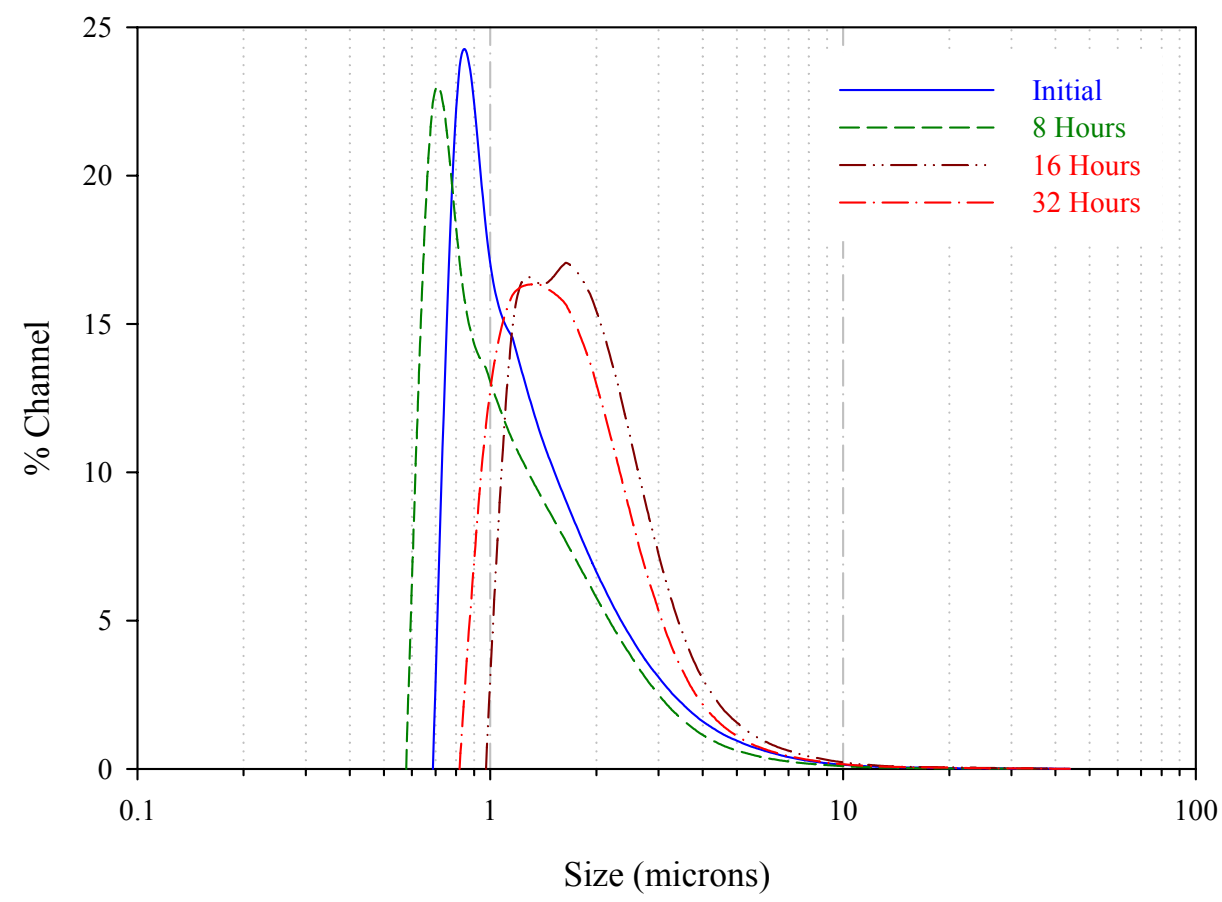

Figure A- 2 Impact of Thermal Aging $\left(90^{\circ} \mathrm{C}\right)$ on Particle Size Distribution Number Basis on Gravity-Washed SB3 Sludge Simulant 


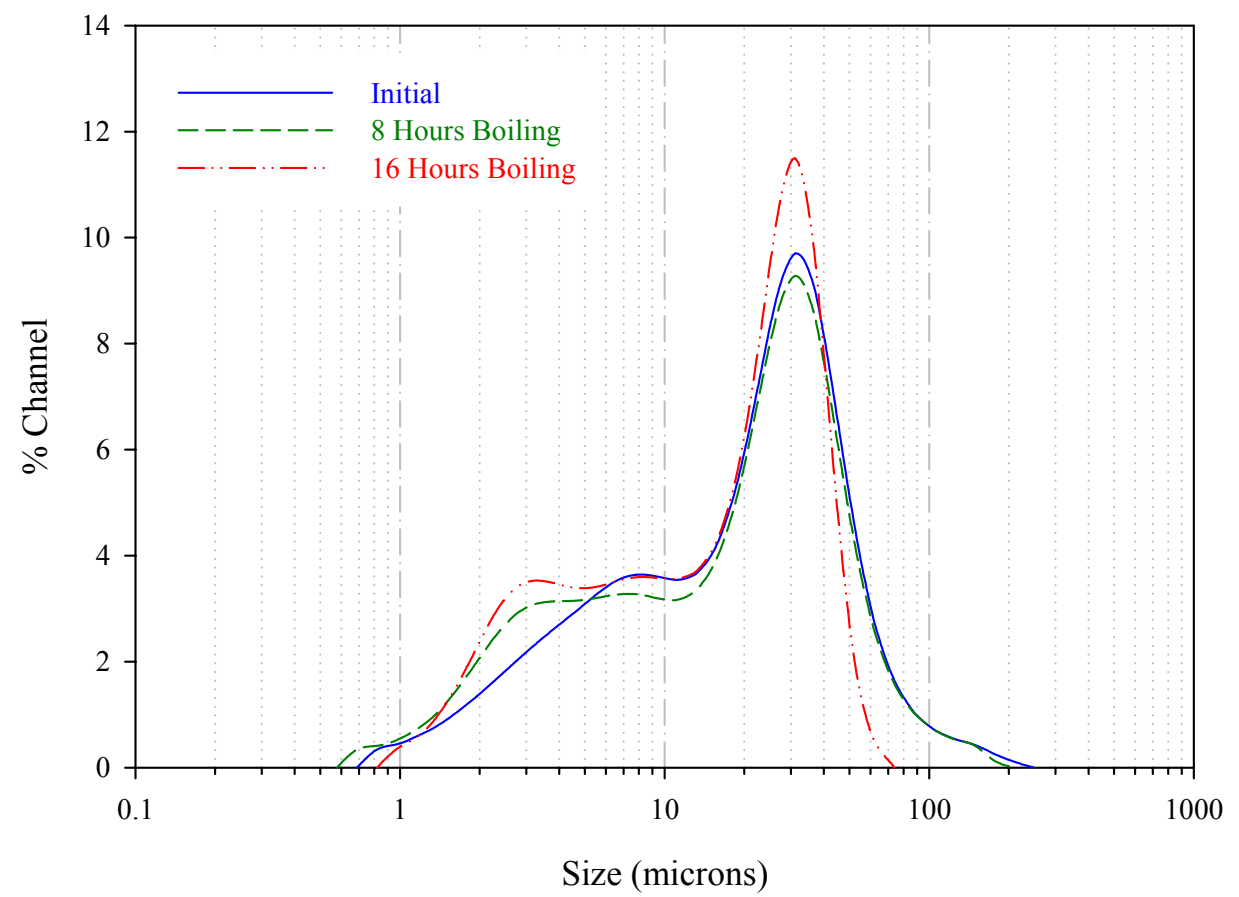

Figure A- 3 Impact of Thermal Aging (Boiling) on Particle Size Distribution Volume Basis for Gravity-Washed SB3 Sludge Simulant

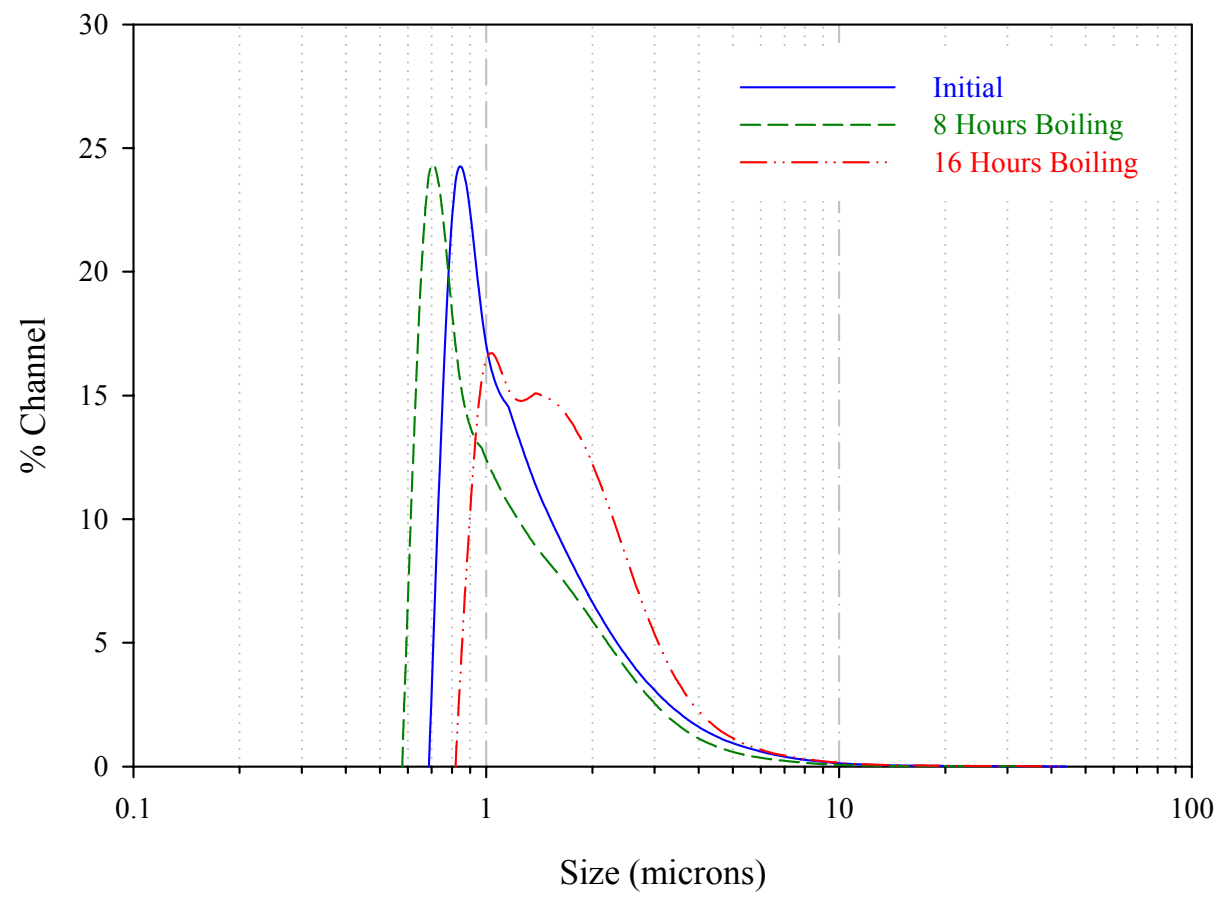

Figure A- 4 Impact of Thermal Aging (Boiling) on Particle Size Distribution Number Basis for Gravity-Washed SB3 Sludge Simulant 


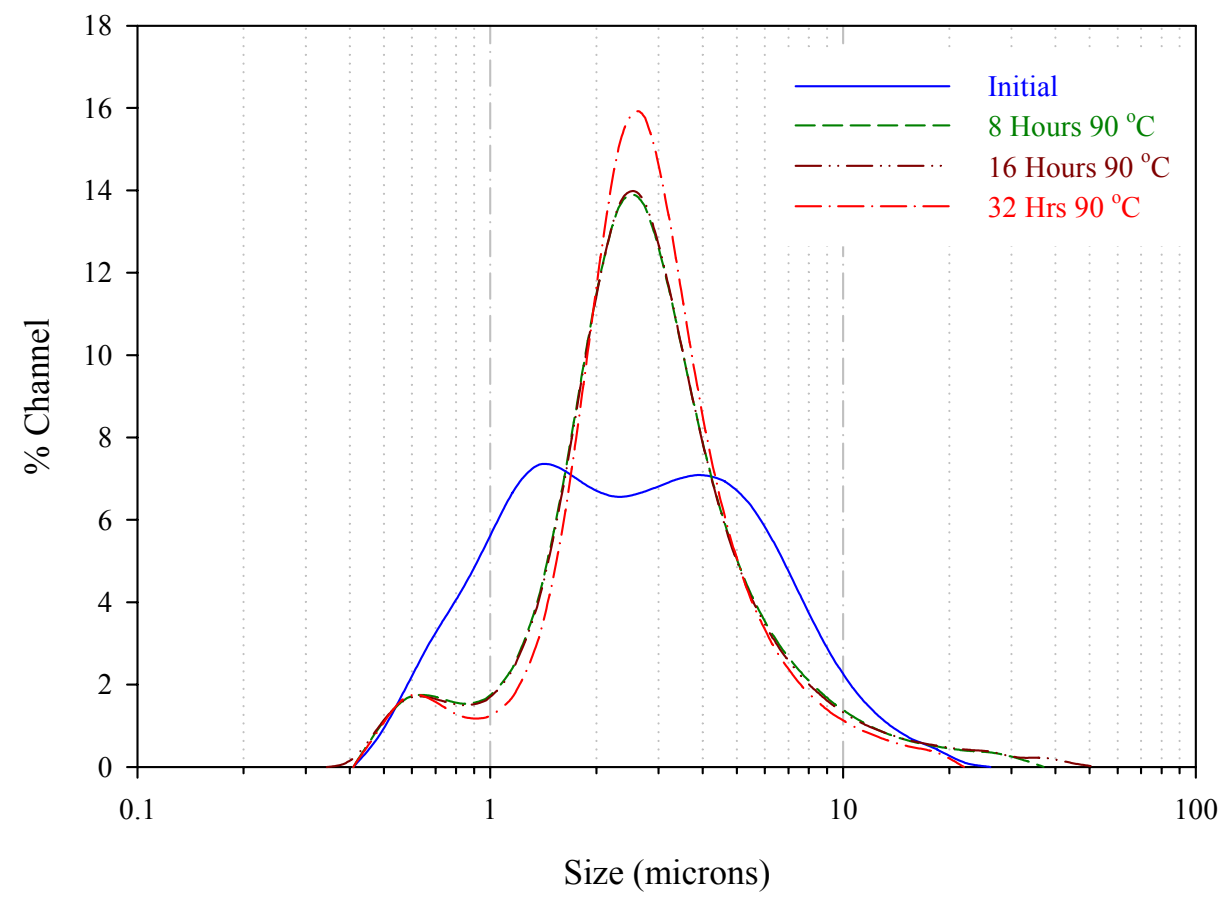

Figure A- 5 Impact of Thermal Aging $\left(90^{\circ} \mathrm{C}\right)$ on Particle Size Distribution Volume Basis for Crossflow-Washed SB3 Sludge Simulant

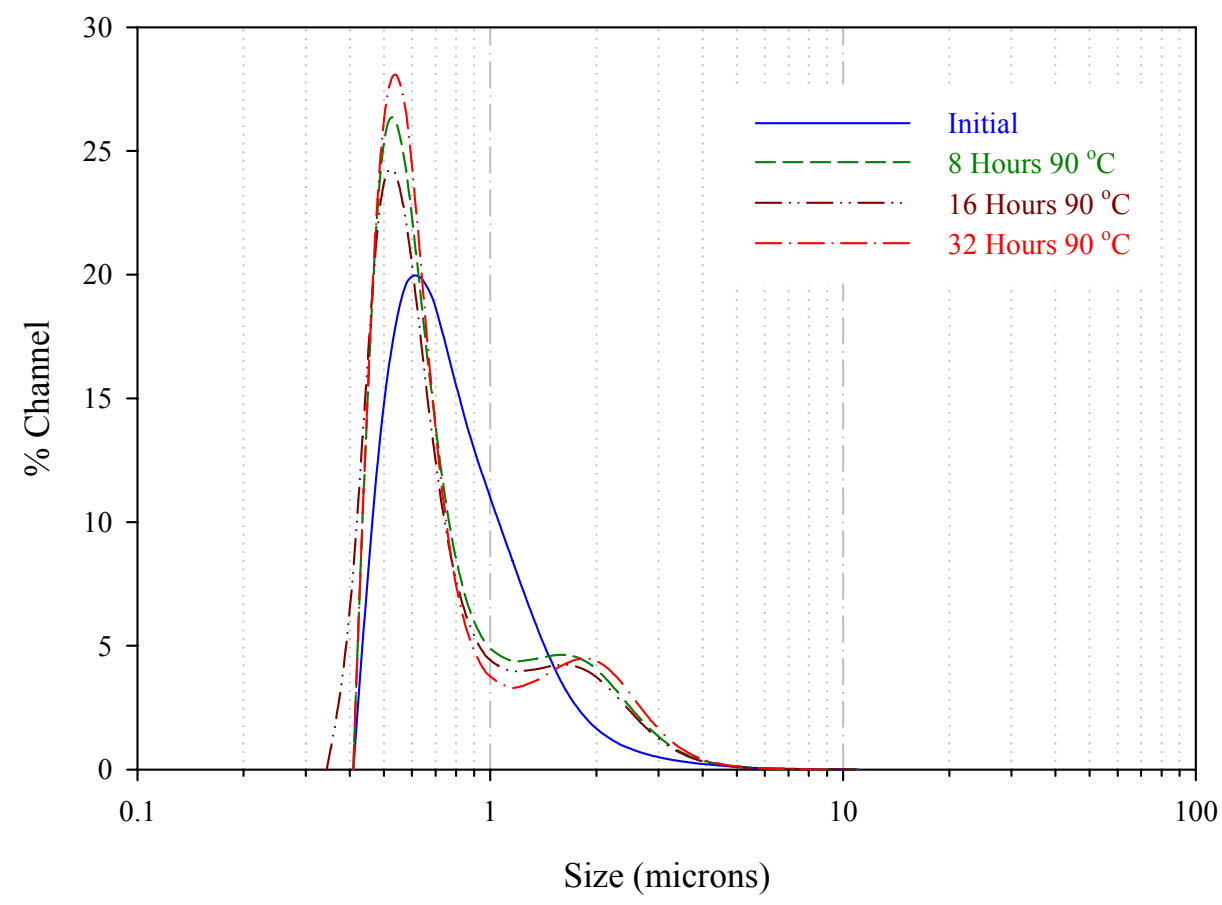

Figure A- 6 Impact of Thermal Aging $\left(90^{\circ} \mathrm{C}\right)$ on Particle Size Distribution Number Basis for Crossflow-Washed SB3 Sludge Simulant 
WSRC-TR-2005-00543

Revision 0

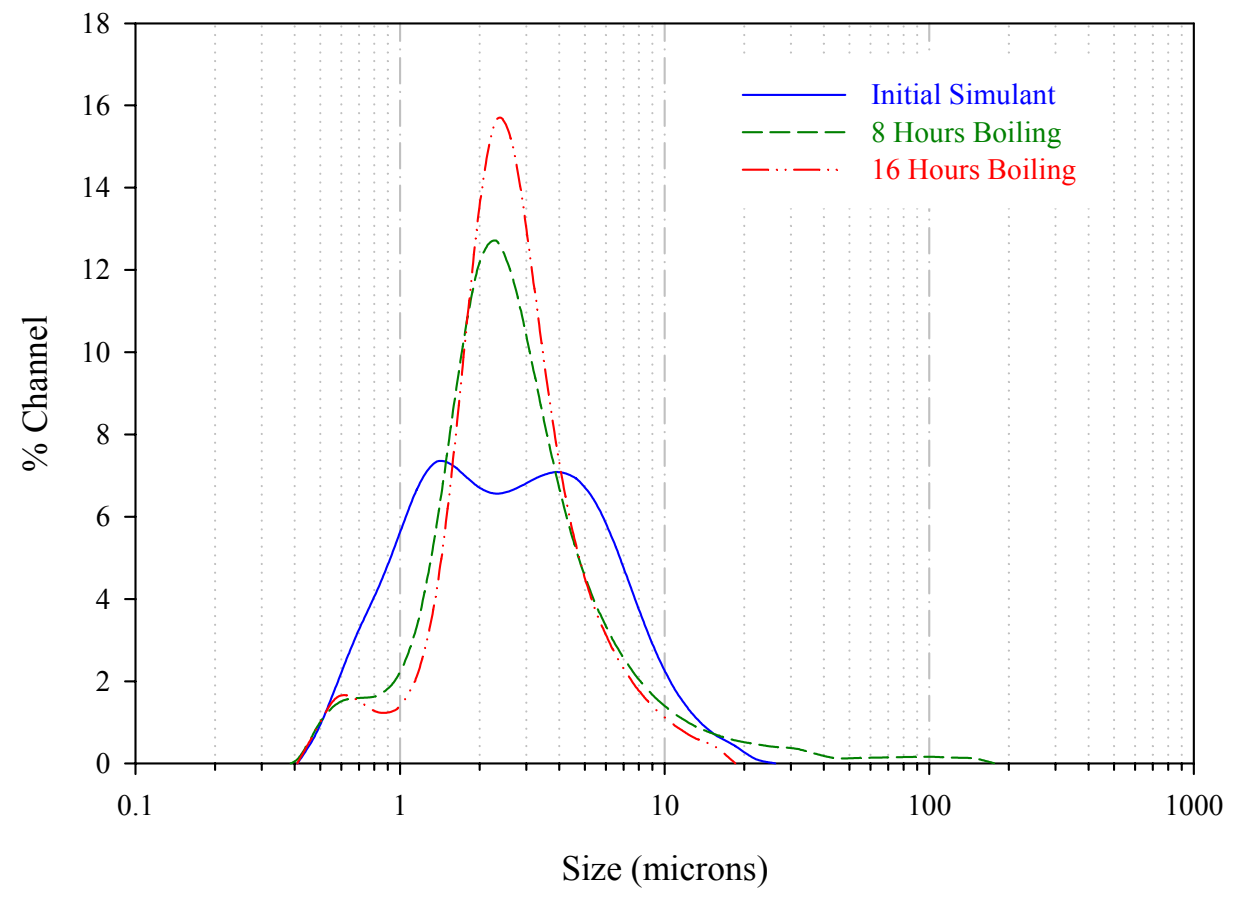

Figure A- 7 Impact of Thermal Aging (Boiling) on Particle Size Distribution Volume Basis for Crossflow-Washed SB3 Sludge Simulant

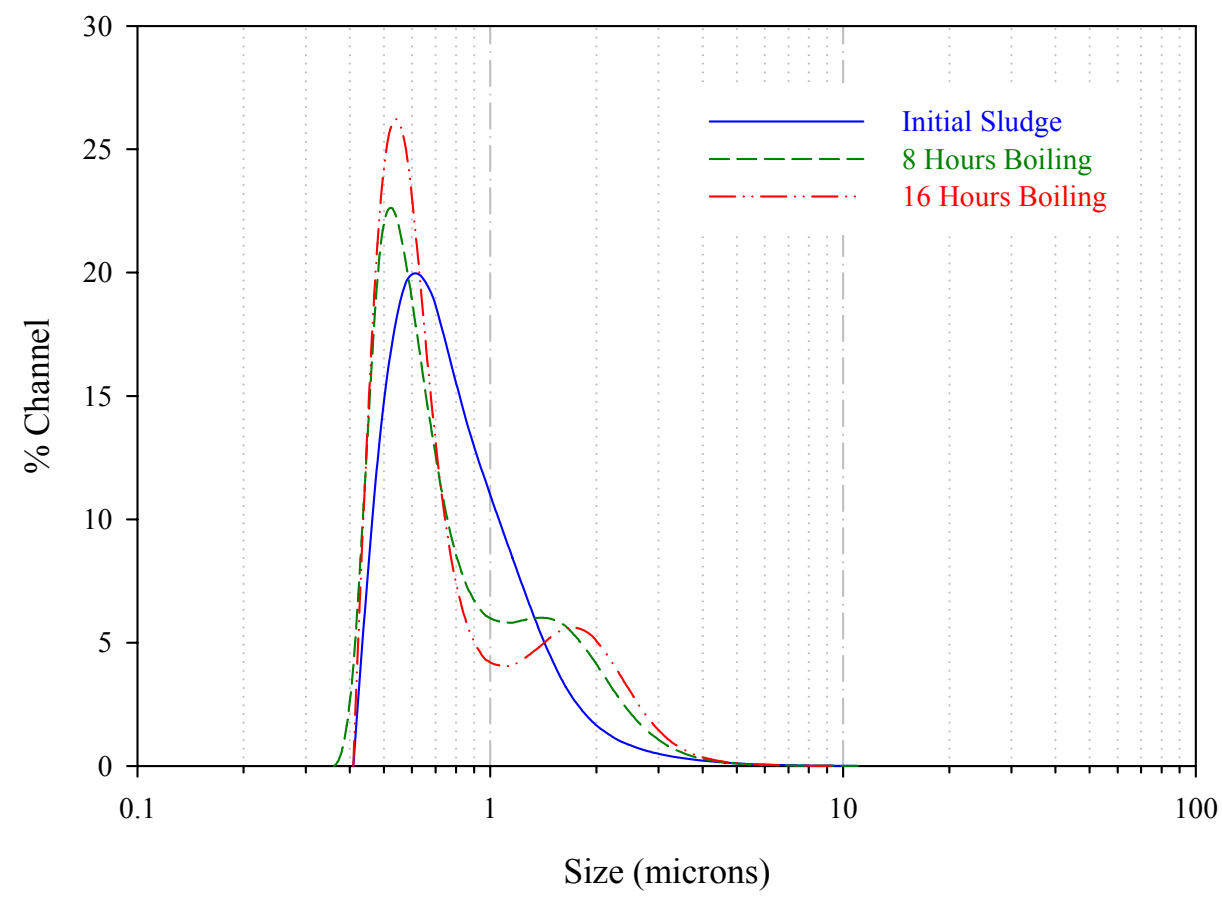

Figure A- 8 Impact of Thermal Aging (Boiling) on Particle Size Distribution Number Basis for Crossflow-Washed SB3 Sludge Simulant 
WSRC-TR-2005-00543

Revision 0

This page intentionally left blank. 
WSRC-TR-2005-00543

Revision 0

APPENDIX B. Rheograms for Gravity-Washed and Crossflow-Washed Simulants 
Initial Test 9 Gravity-Washed SB3 Simulant

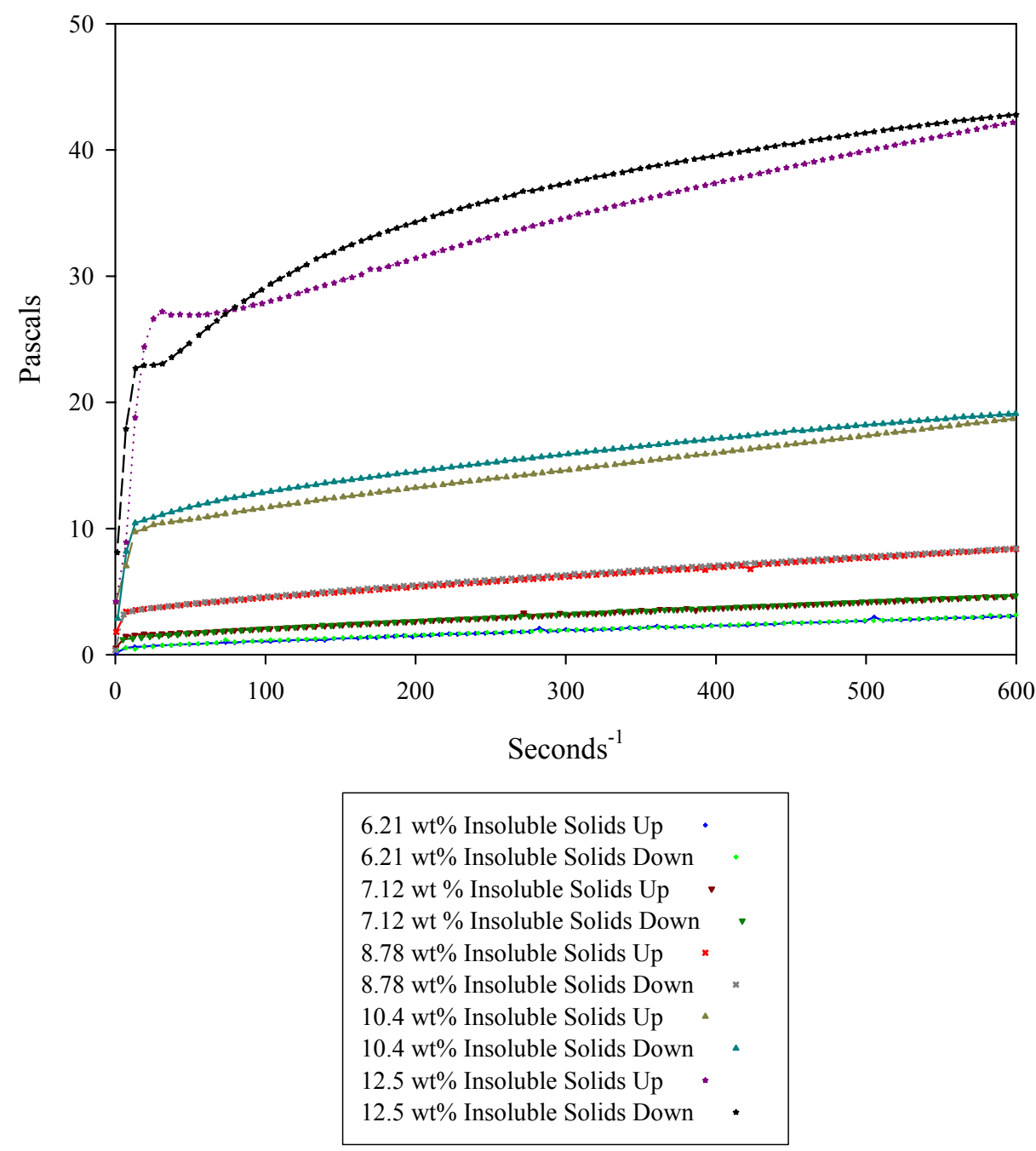

Figure B- 1 Rheograms for the Initial Gravity-Washed SB3 Simulant at Varying Concentrations of Insoluble Solids 
Test 9-H1 Gravity-Washed SB3 Simulant After 8 Hours at $90{ }^{\circ} \mathrm{C}$

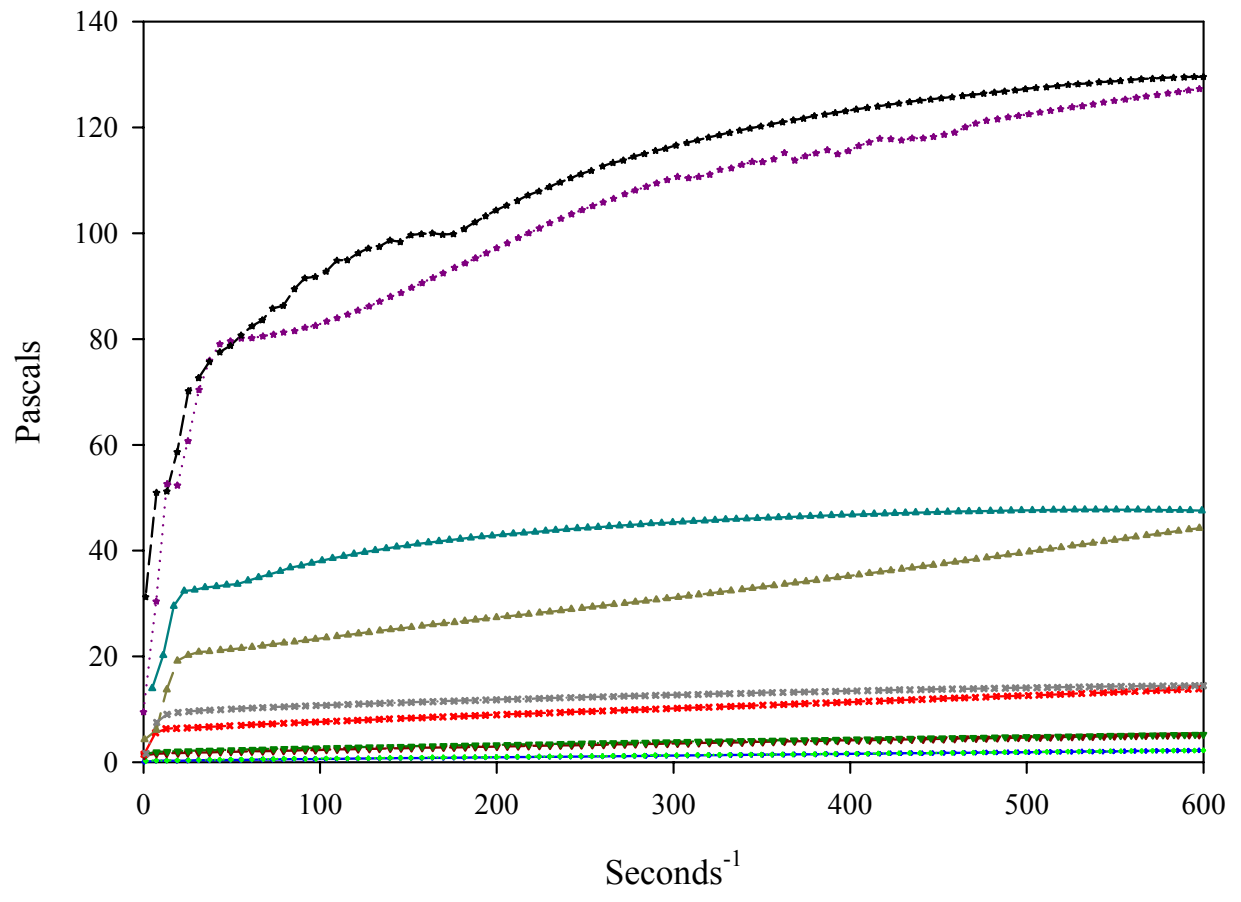

$$
\begin{aligned}
& 5.50 \mathrm{wt} \% \text { Insoluble Solids Up } \\
& 5.50 \mathrm{wt} \% \text { Insoluble Solids Down } \\
& 7.88 \mathrm{wt} \% \text { Insoluble Solids Up } \\
& 7.88 \mathrm{wt} \% \text { Insoluble Solids Down } \\
& 9.98 \mathrm{wt} \% \text { Insoluble Solids Up } \\
& 9.98 \mathrm{wt} \% \text { Insoluble Solids Down } \\
& 12.7 \mathrm{wt} \% \text { Insoluble Solids Up } \\
& 12.7 \mathrm{wt} \% \text { Insolulble Solids Down } \\
& 15.8 \mathrm{wt} \% \text { Insoluble Solids Up } \\
& 15.8 \mathrm{wt} \% \text { Insoluble Solids Down }
\end{aligned}
$$

Figure B- 2 Rheograms for the Gravity-Washed SB3 Simulant After 8 Hours at $90^{\circ} \mathrm{C}$ as a Function of Insoluble Solids 
Test 9-H2 Gravity-Washed SB3 Simulant

After 16 Hours at $90{ }^{\circ} \mathrm{C}$

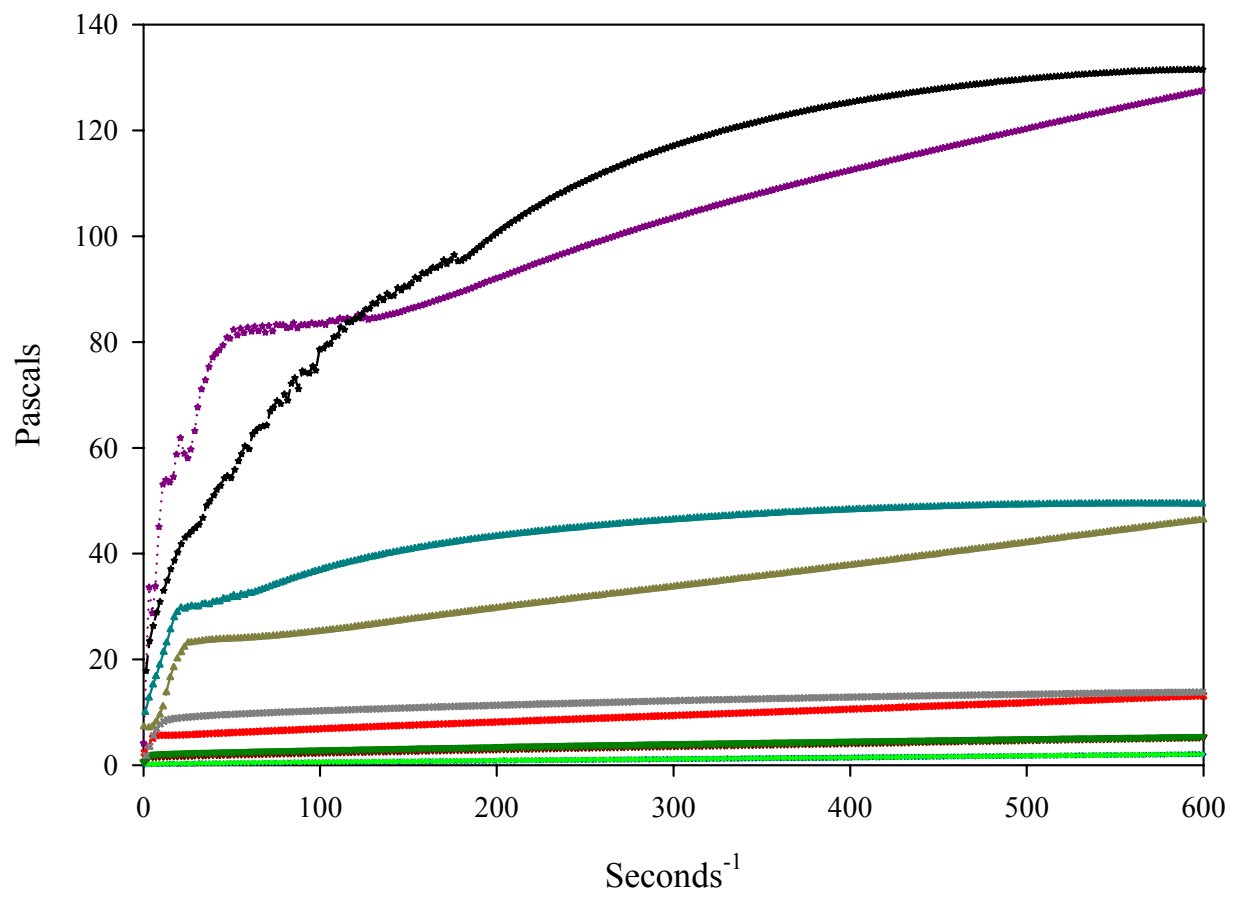

$5.39 \mathrm{wt} \%$ Insoluble Solids Up

$5.39 \mathrm{wt} \%$ Insoluble Solids Down

$7.97 \mathrm{wt} \%$ Insoluble Solids Up •

$7.97 \mathrm{wt} \%$ Insoluble Solids Down -

$10.4 \mathrm{wt} \%$ Insoluble Solids Up *

10.4 wt\% Insoluble Solids Down *

$12.7 \mathrm{wt} \%$ Insoluble Solids Up

$12.7 \mathrm{wt} \%$ Insoluble Solids Down

$16.7 \mathrm{wt} \%$ Insoluble Solids Up *

$16.7 \mathrm{wt} \%$ Insoluble Solids Down *

Figure B- 3 Rheograms for the Gravity-Washed SB3 Simulant After 16 Hours at $90^{\circ} \mathrm{C}$ as a Function of Insoluble Solids 
Test 9-H3 Gravity-Washed SB3 Simulant After 8 Hours at Boiling

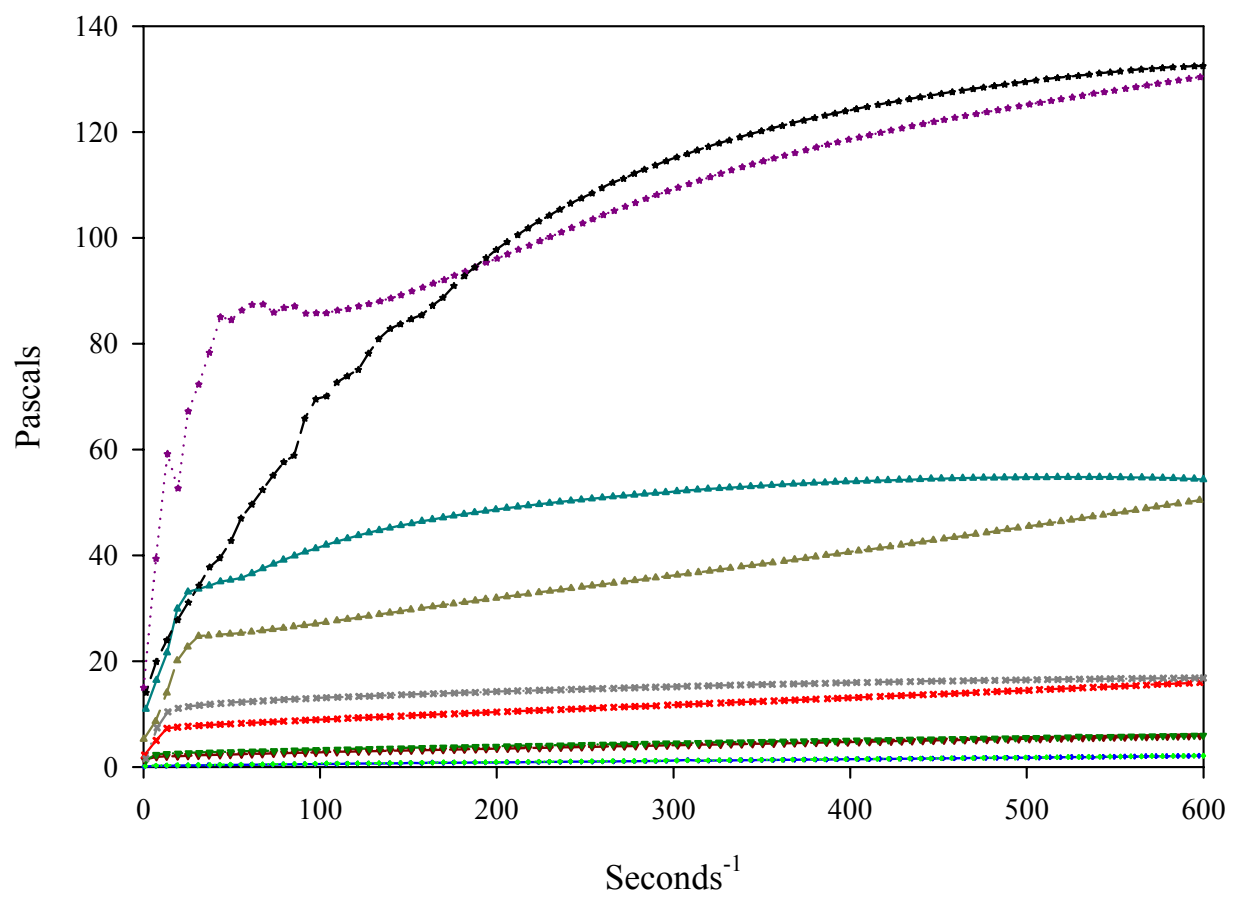

$5.45 \mathrm{wt} \%$ Insoluble Solids Up

$5.45 \mathrm{wt} \%$ Insoluble Solids Down

$8.25 \mathrm{wt} \%$ Insoluble Solids Up

$8.25 \mathrm{wt} \%$ Insoluble Solids Down .

$10.3 \mathrm{wt} \%$ Insoluble Solids Up $\quad$ *

10.3 wt \% Insoluble Solids Down

$13.1 \mathrm{wt} \%$ Insoluble Solids Up

$13.1 \mathrm{wt} \%$ Insoluble Solids Down

$15.7 \mathrm{wt} \%$ Insoluble Solids Up *

15.7 wt \% Insoluble Solids Down

Figure B- 4 Rheograms for the Gravity-Washed SB3 Simulant After 8 Hours at Boiling as a Function of Insoluble Solids 
Test 9-H4 Gravity-Washed SB3 Simulant After 16 Hours Boiling

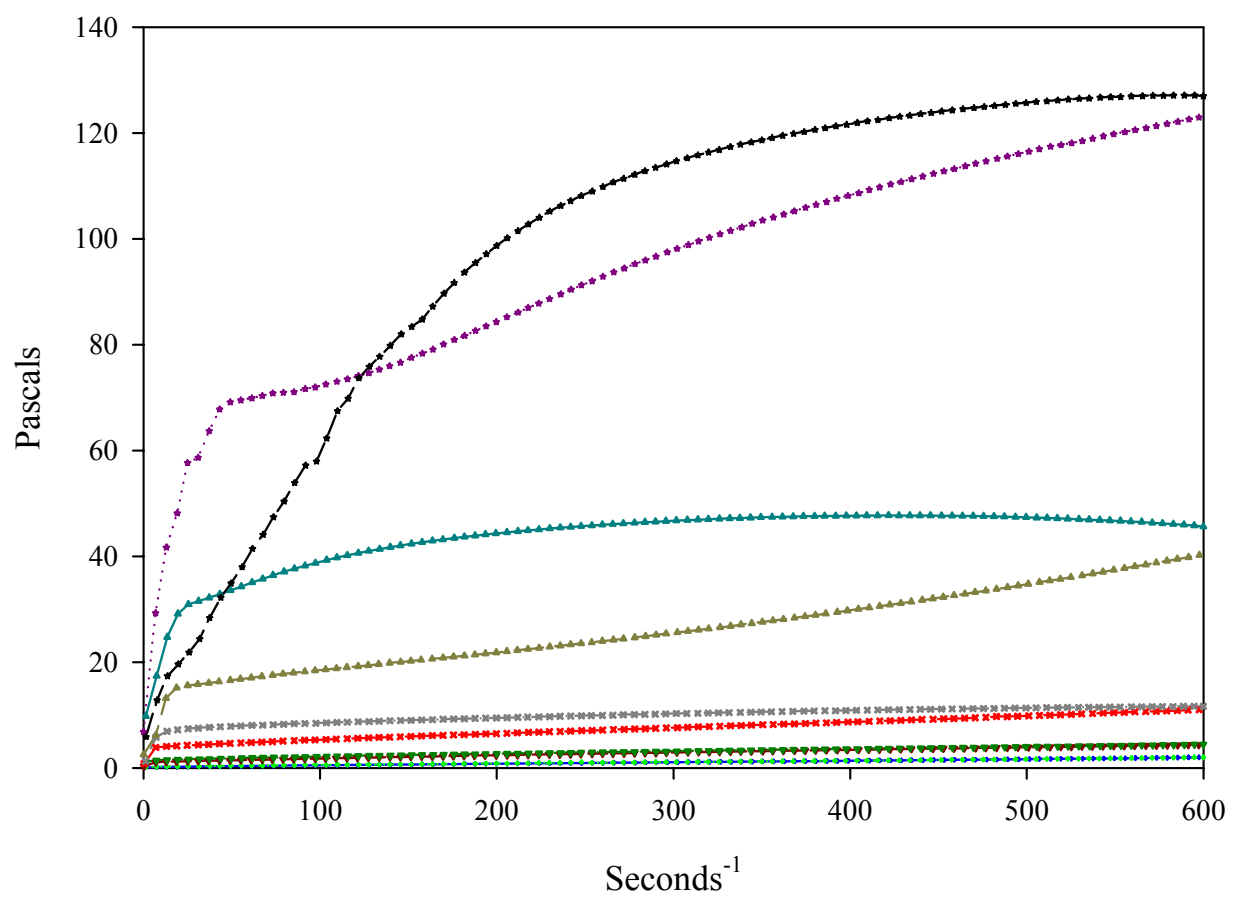

$5.29 \mathrm{wt} \%$ Insoluble Solids Up
$5.29 \mathrm{wt} \%$ Insoluble Solids Down
$7.91 \mathrm{wt} \%$ Insoluble Solids Up
$7.91 \mathrm{wt} \%$ Insoluble Solids Down
$10.2 \mathrm{wt} \%$ Insoluble Solids Up
$10.2 \mathrm{wt} \%$ Insoluble Solids Down
$12.7 \mathrm{wt} \%$ Insoluble Solids Up
$12.7 \mathrm{wt} \%$ Insoluble Solids Down
$15.9 \mathrm{wt} \%$ Insoluble Solids Up *
$15.9 \mathrm{wt} \%$ Insoluble Solids Down

Figure B- 5 Rheograms for the Gravity-Washed SB3 Simulant After 16 Hours at Boiling as a Function of Insoluble Solids 
Test 9-H5 Gravity-Washed SB3 Simulant

After 32 Hours at $90{ }^{\circ} \mathrm{C}$

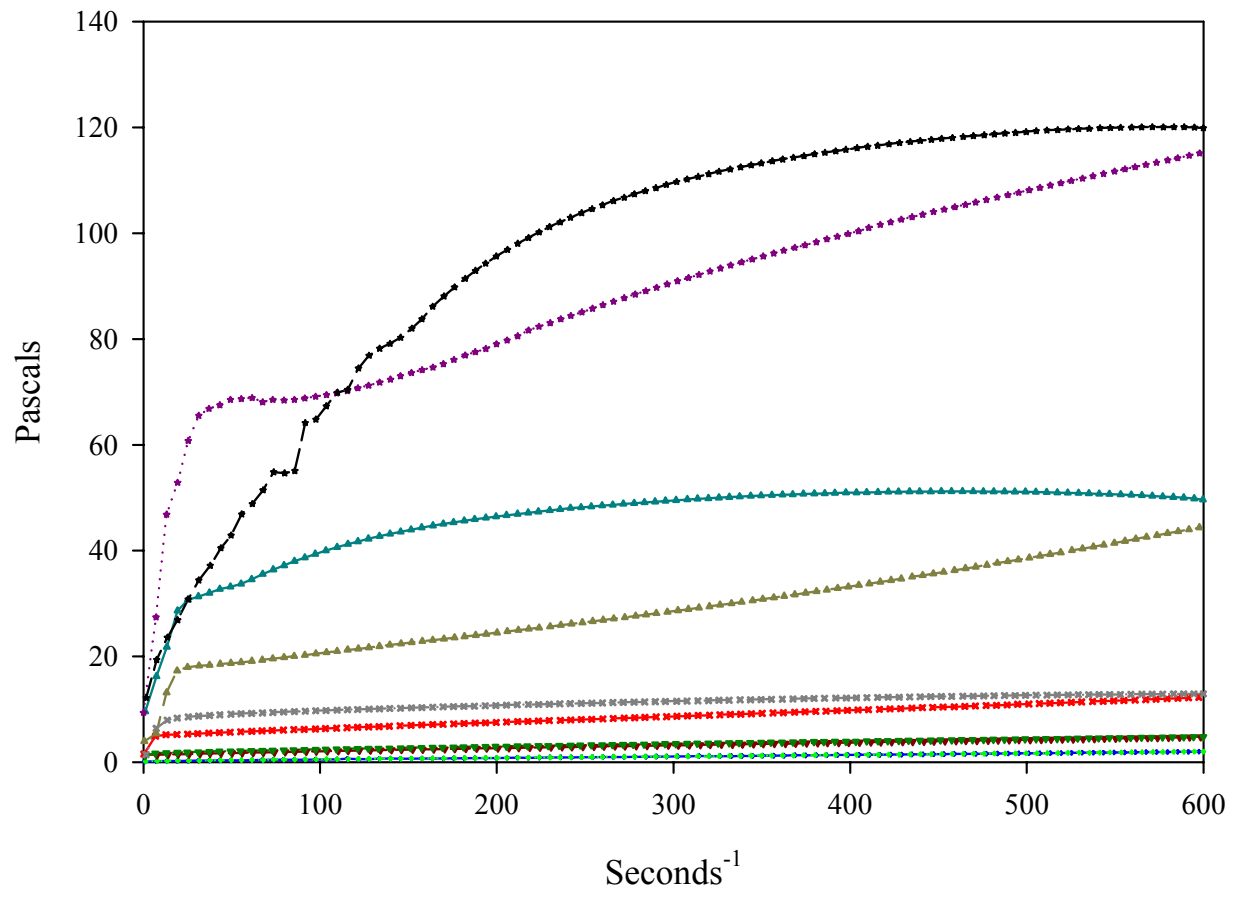

$5.31 \mathrm{wt} \%$ Insoluble Solids Up .

$5.31 \mathrm{wt} \%$ Insoluble Solids Down

$8.07 \mathrm{wt} \%$ Insoluble Solids Up •

$8.07 \mathrm{wt} \%$ Insoluble Solids Down •

$10.4 \mathrm{wt} \%$ Insoluble Solids Up *

$10.4 \mathrm{wt} \%$ Insoluble Solids Down *

$12.6 \mathrm{wt} \%$ Insoluble Solids Up

$12.6 \mathrm{wt} \%$ Insoluble Solids Down

$16.0 \mathrm{wt} \%$ Insoluble Solids Up *

$16.0 \mathrm{wt} \%$ Insoluble Solids Down *

Figure B- 6 Rheograms for the Gravity-Washed SB3 Simulant

After 32 Hours at $90{ }^{\circ} \mathrm{C}$ as a Function of Insoluble Solids 
WSRC-TR-2005-00543

Revision 0

Initial Test 10 Crossflow-Washed SB3 Simulant

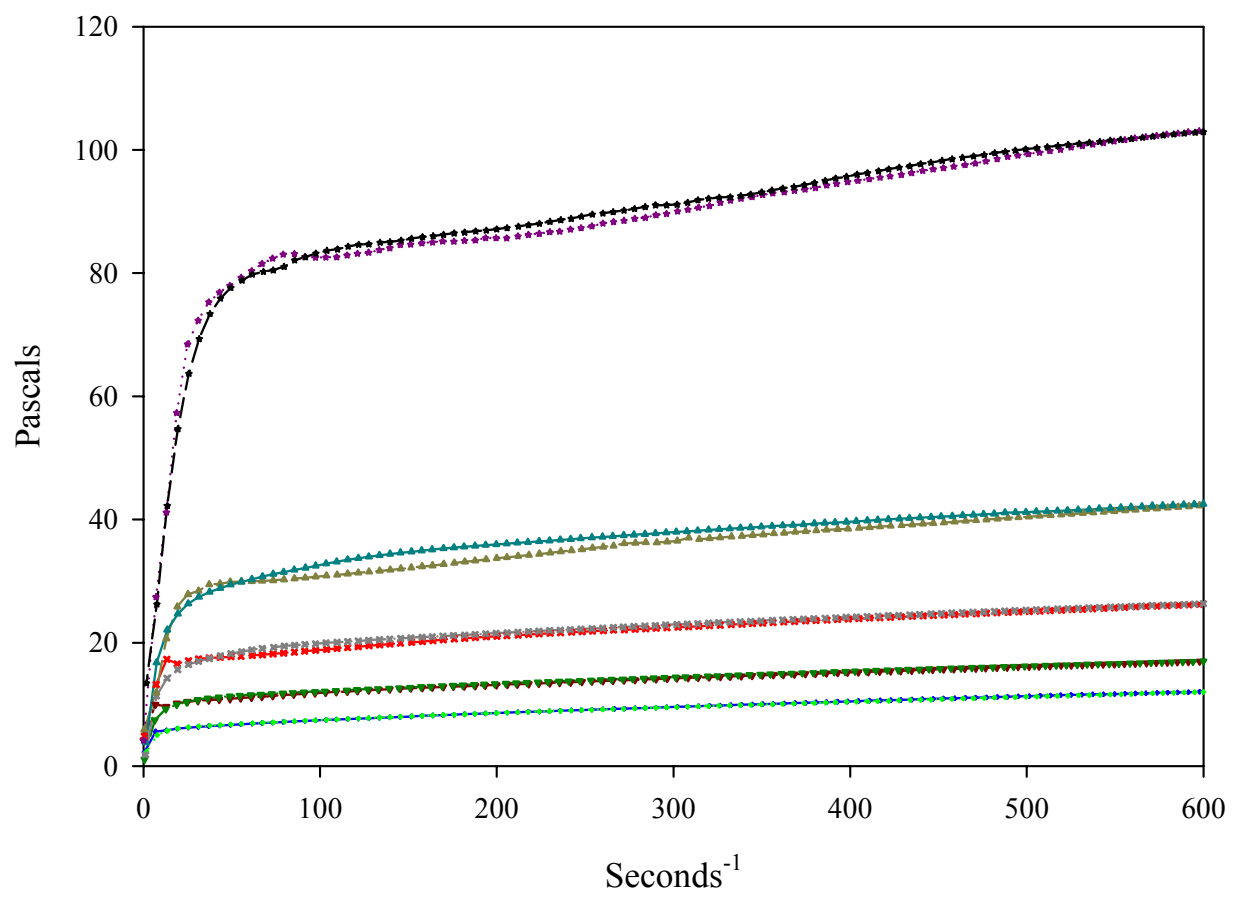

9.29 wt\% Insoluble Solids Up •

$9.29 \mathrm{wt} \%$ Insoluble Solids Down

$9.87 \mathrm{wt} \%$ Insoluble Solids Up .

9.87 wt\% Insoluble Solids Down •

$11.2 \mathrm{wt} \%$ Insoluble Solids Up *

$11.2 \mathrm{wt} \%$ Insoluble Solids Down "

$12.6 \mathrm{wt} \%$ Insoluble Solids Up A

$12.6 \mathrm{wt} \%$ Insoluble Solids Down

$16.2 \mathrm{wt} \%$ Insoluble Solids Up *

16.2 wt\% Insoluble Solids Down *

Figure B- 7 Rheograms for the Initial Crossflow-Washed SB3 Simulant at Varying Concentrations of Insoluble Solids 
Test 10-H1 Crossflow-Washed SB3 Simulant After 8 Hours at $90{ }^{\circ} \mathrm{C}$

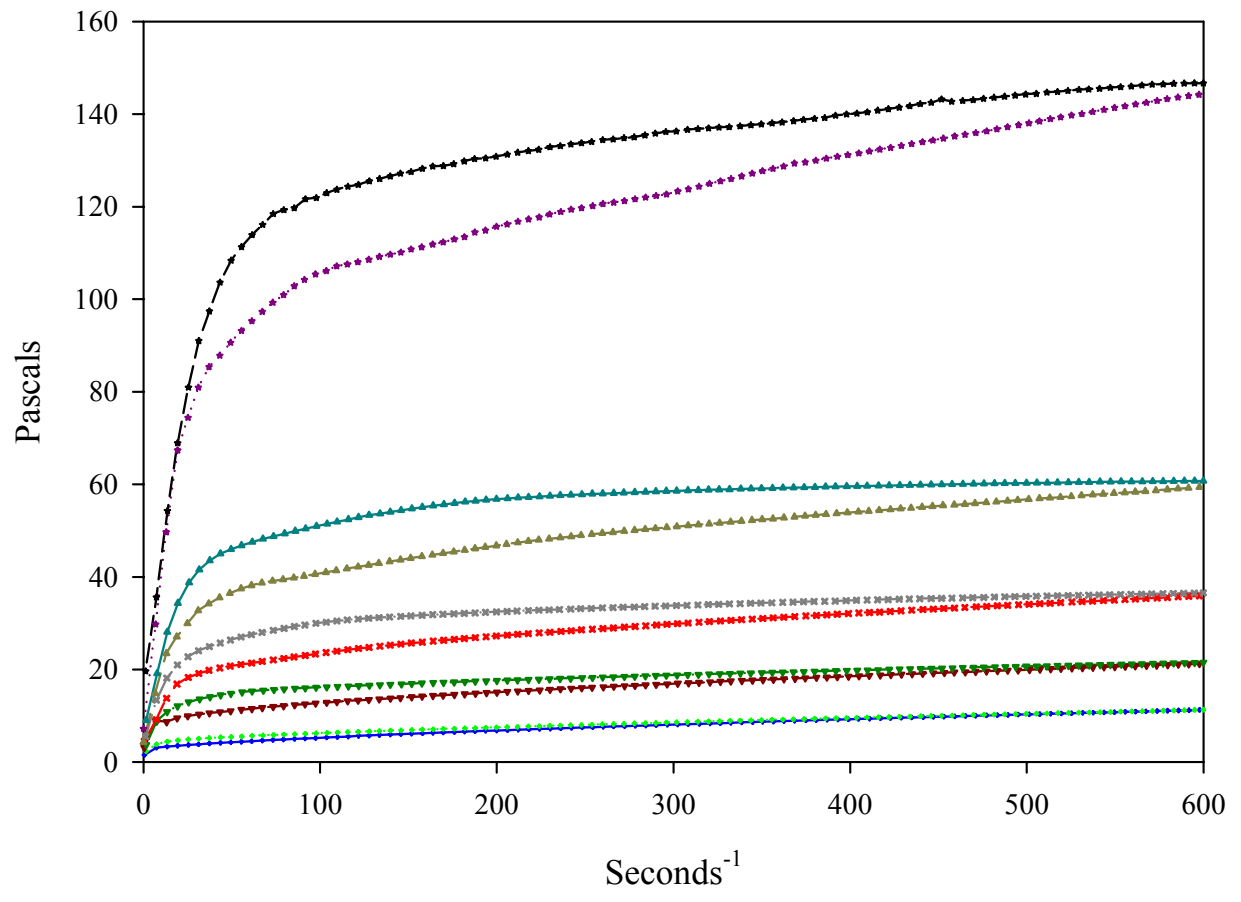

$9.02 \mathrm{wt} \%$ Insoluble Solids Up .

9.02 wt\% Insoluble Solids Down

$10.1 \mathrm{wt} \%$ Insoluble Solids Up •

$10.1 \mathrm{wt} \%$ Insoluble Solids Down .

$11.3 \mathrm{wt} \%$ Insoluble Solids Up *

$11.3 \mathrm{wt} \%$ Insoluble Solids Down *

$12.5 \mathrm{wt} \%$ Insoluble Solids Up

$12.5 \mathrm{wt} \%$ Insoluble Solids Down

$15.6 \mathrm{wt} \%$ Insoluble Solids Up *

$15.6 \mathrm{wt} \%$ Insoluble Solids Down

Figure B- 8 Rheograms for the Crossflow-Washed SB3 Simulant After 8 Hours at $90^{\circ} \mathrm{C}$ as a Function of Insoluble Solids 
Test 10-H2 Crossflow-Washed SB3 Simulant After 16 Hours at $90{ }^{\circ} \mathrm{C}$

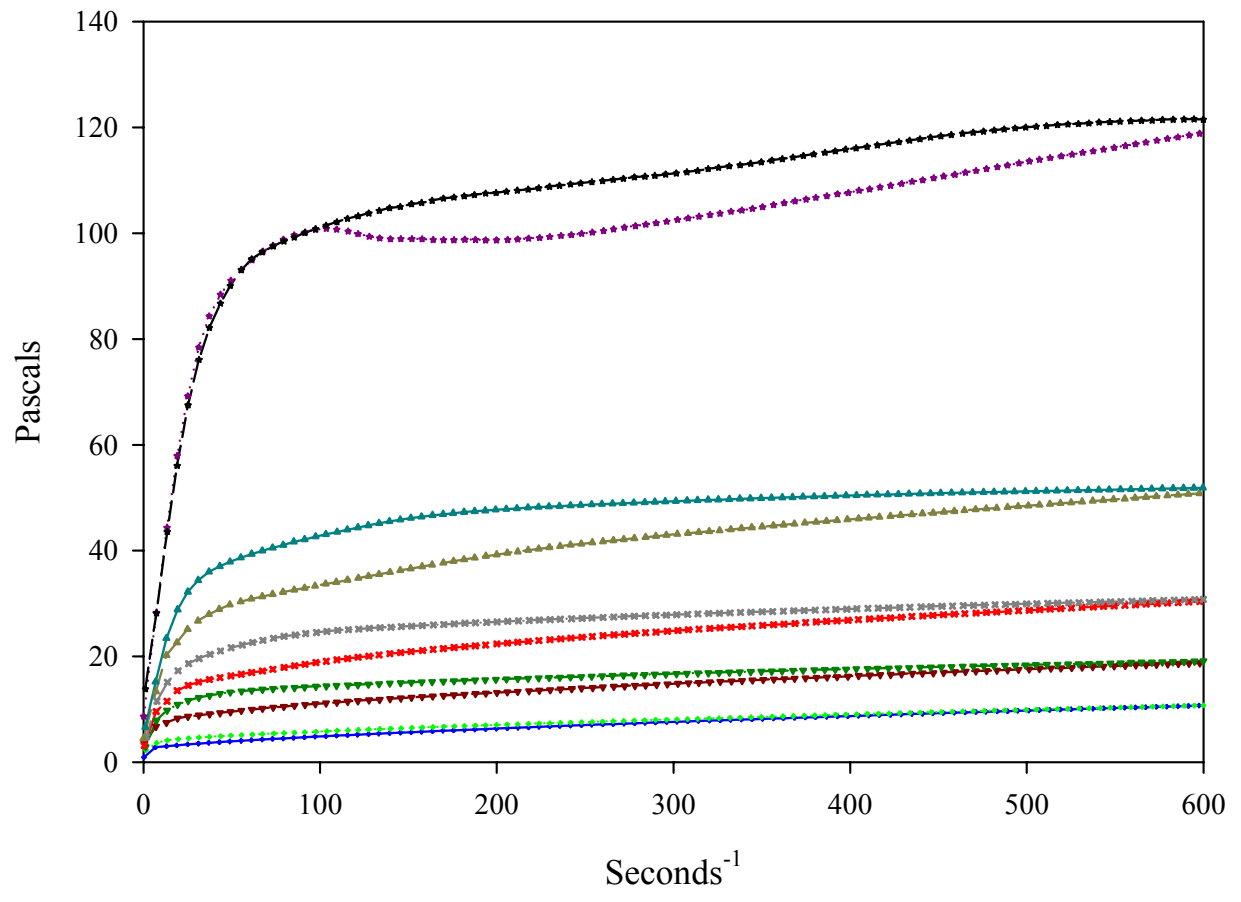

$9.22 \mathrm{wt} \%$ Insoluble Solids Up •

$9.22 \mathrm{wt} \%$ Insoluble Solids Down

$9.88 \mathrm{wt} \%$ Insoluble Solids Up •

$9.88 \mathrm{wt} \%$ Insoluble Solids Down •

$10.8 \mathrm{wt} \%$ Insoluble Solids Up *

10.8 wt\% Insoluble Solids Down *

$12.7 \mathrm{wt} \%$ Insoluble Solids Up

$12.7 \mathrm{wt} \%$ Insoluble Solids Down

$16.2 \mathrm{wt} \%$ Insoluble Solids Up *

$16.2 \mathrm{wt} \%$ Insoluble Solids Down

Figure B- 9 Rheograms for the Crossflow-Washed SB3 Simulant After 16 Hours at $90^{\circ} \mathrm{C}$ as a Function of Insoluble Solids 
Test 10-H3 Crossflow-Washed SB3 Simulant After 8 Hours at Boiling

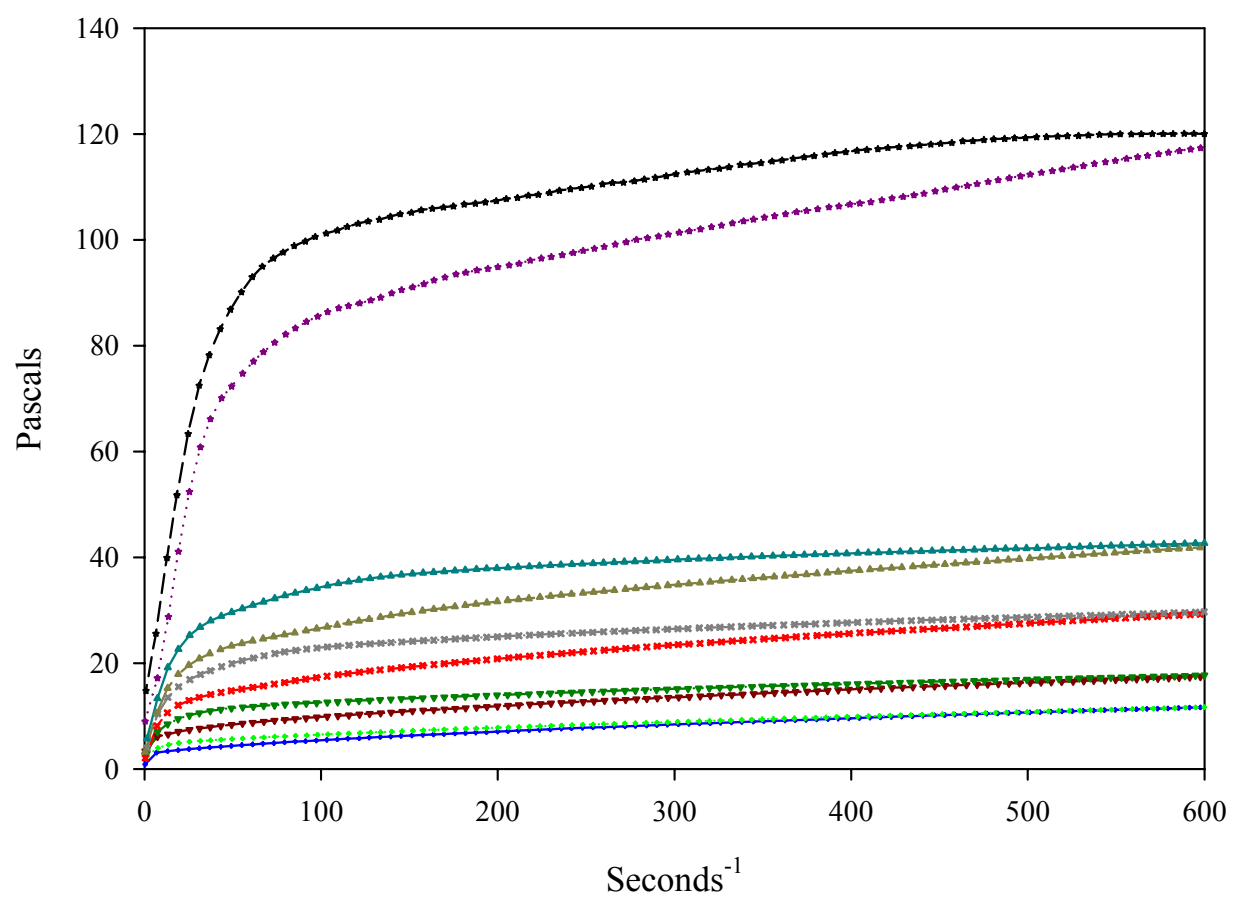

$9.37 \mathrm{wt} \%$ Insoluble Solids Up . $9.37 \mathrm{wt} \%$ Insoluble Solids Down $9.56 \mathrm{wt} \%$ Insoluble Solids Up • $9.56 \mathrm{wt} \%$ Insoluble Solids Down $10.9 \mathrm{wt} \%$ Insoluble Solids Up * $10.9 \mathrm{wt} \%$ Insoluble Solids Down $11.7 \mathrm{wt} \%$ Insoluble Solids Up $11.7 \mathrm{wt} \%$ Insoluble Solids Down $14.9 \mathrm{wt} \%$ Insoluble Solids Up * $14.9 \mathrm{wt} \%$ Insoluble Solids Down

Figure B-10 Rheograms for the Crossflow-Washed SB3 Simulant After 8 Hours at Boiling as a Function of Insoluble Solids 
Test 10-H4 Crossflow-Washed SB3 Simulant After 16 Hours at Boiling

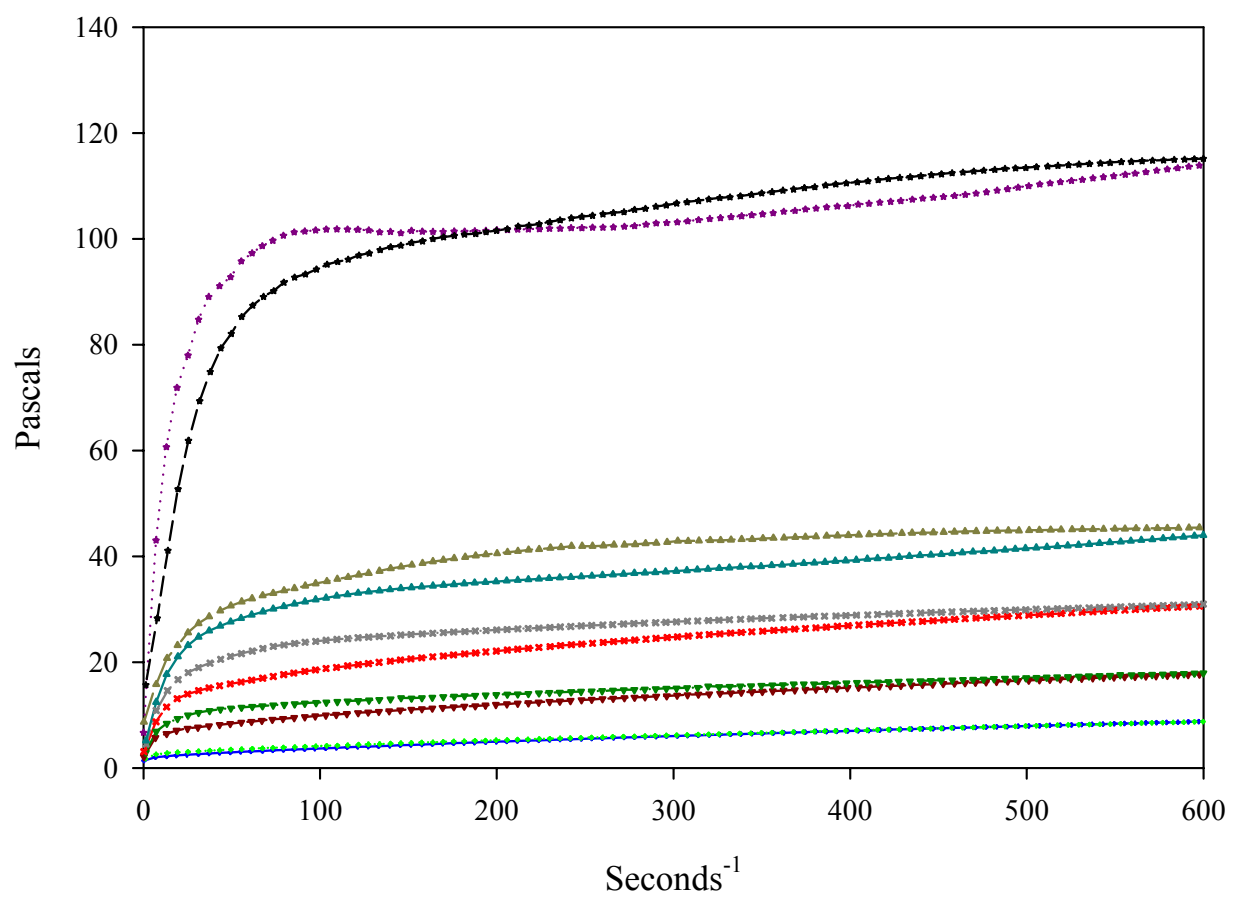

8.93 wt\% Insoluble Solids Up . $8.93 \mathrm{wt} \%$ Insoluble Solids Down $9.90 \mathrm{wt} \%$ Insoluble Solids Up $9.90 \mathrm{wt} \%$ Insoluble Solids Down . $11.3 \mathrm{wt} \%$ Insoluble Solids Up $\quad$ $11.3 \mathrm{wt} \%$ Insoluble Solids Down $12.6 \mathrm{wt} \%$ Insoluble Solids Up $12.6 \mathrm{wt} \%$ Insoluble Solids Down $15.2 \mathrm{wt} \%$ Insoluble Solids Up * $15.2 \mathrm{wt} \%$ Insoluble Solids Down

Figure B- 11 Rheograms for the Crossflow-Washed SB3 Simulant After 16 Hours at Boiling as a Function of Insoluble Solids 
Test 10-H5 Crossflow-Washed SB3 Simulant

After 32 Hours at $90{ }^{\circ} \mathrm{C}$

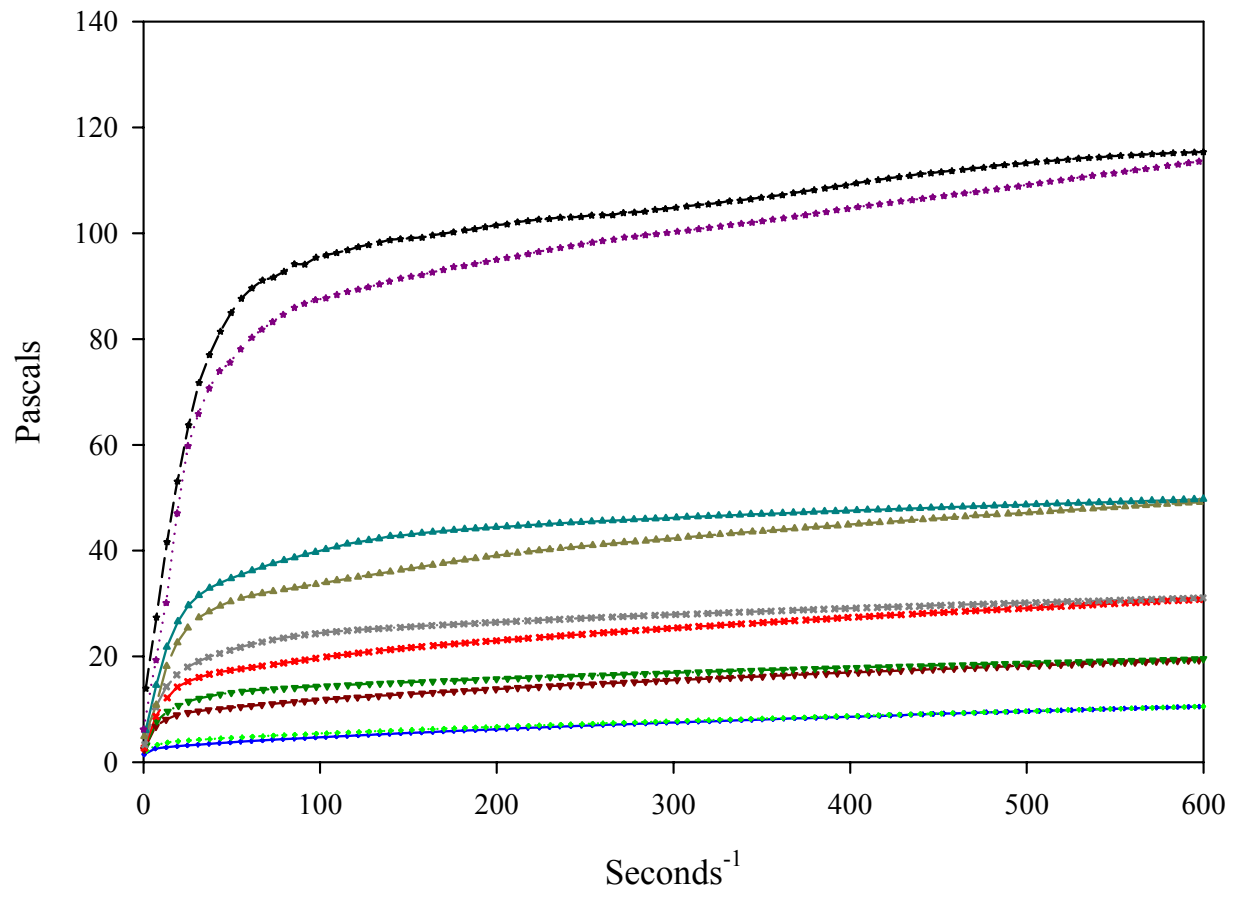

9.11wt\% Insoluble Solids Up .

$9.11 \mathrm{wt} \%$ Insoluble Solids Down

$9.57 \mathrm{wt} \%$ Insoluble Solids Up •

$9.57 \mathrm{wt} \%$ Insoluble Solids Down -

$11.1 \mathrm{wt} \%$ Insoluble Solids Up *

$11.1 \mathrm{wt} \%$ Insoluble Solids Down *

$12.4 \mathrm{wt} \%$ Insoluble Solids Up

$12.4 \mathrm{wt} \%$ Insoluble Solids Down

$15.5 \mathrm{wt} \%$ Insoluble Solids Up *

$15.5 \mathrm{wt} \%$ Insoluble Solids Down

Figure B- 12 Rheograms for the Crossflow-Washed SB3 Simulant After 32 Hours at $90^{\circ} \mathrm{C}$ as a Function of Insoluble Solids 
Test 10-EW Crossflow-Washed SB3 Simulant After 27 Hours at Boiling

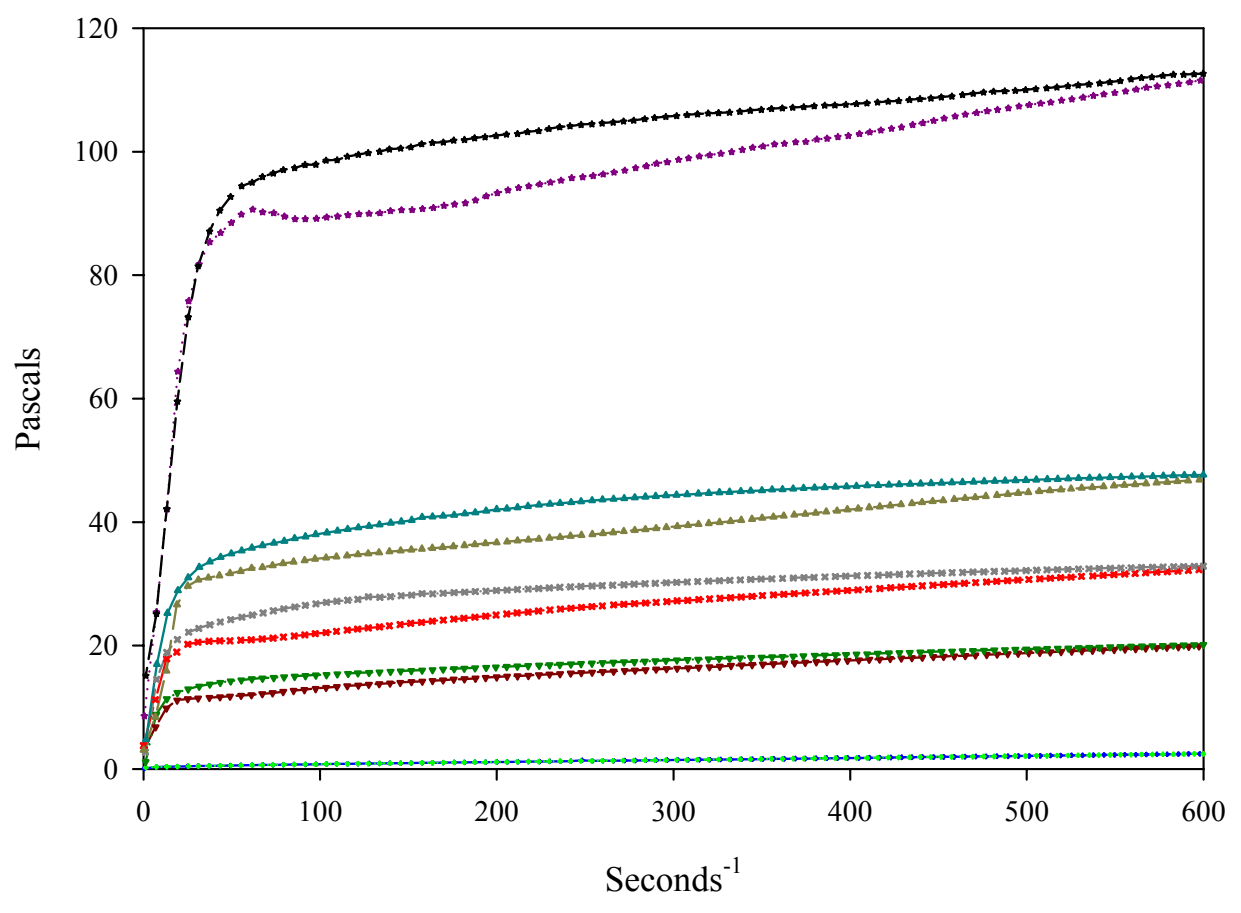

$5.37 \mathrm{wt} \%$ Insoluble Solids Up .

$5.37 \mathrm{wt} \%$ Insoluble Solids Down

$9.97 \mathrm{wt} \%$ Insoluble Solids Up •

$9.97 \mathrm{wt} \%$ Insoluble Solids Down .

$11.8 \mathrm{wt} \%$ Insoluble Solids Up *

$11.8 \mathrm{wt} \%$ Insoluble Solids Down

$12.6 \mathrm{wt} \%$ Insoluble Solids Up

$12.6 \mathrm{wt} \%$ Insoluble Solids Down

$15.5 \mathrm{wt} \%$ Insoluble Solids Up *

$15.5 \mathrm{wt} \%$ Insoluble Solids Down

Figure B- 13 Rheograms for the Extended-Washed SB3 Simulant After 27 Hours at Boiling as a Function of Insoluble Solids 


\section{Distribution:}

R. E. Edwards, SRNL

D. A. Crowley, 999-W

C. C. Herman, 999-W

T. B. Calloway, 999-W

D. B. Burns, 786-5A

N. E. Bibler, SRNL

C.M. Jantzen, SRNL

J. R. Harbour, 773-42A

G. G. Wicks, SRNL

M. J. Barnes, 999-W

C. J. Bannochie, 773-42A

E. K. Hansen, 999-W

D. C. Koopman, 999-W

D. P. Lambert, 999-W

J. M. Pareizs, SRNL

T. L. Fellinger, SRNL

M. S. Miller, 704-S

J. E. Occhipinti, 704-S

P. Patel, 704-27S

H. H. Elder, 704-30S

J. F. Iaukea, 704-30S

J. W. Ray, 704-S

M. A. Rios-Armstrong, 766-H

H. B. Shah, 766-H

J. M. Gillam, 766-H 